\title{
Synthesis of Idarubicinone via Global Functionalization of Tetracene
}

David G. Dennis, Mikiko Okumura, David Sarlah

Submitted date: 30/04/2019 Posted date: 02/05/2019

Licence: CC BY-NC-ND 4.0

Citation information: Dennis, David G.; Okumura, Mikiko; Sarlah, David (2019): Synthesis of Idarubicinone via Global Functionalization of Tetracene. ChemRxiv. Preprint.

Herein, we describe the realization of this concept, providing a non-annulative strategy to anthracyclines from a polynuclear arene. Specifically, tetracene was converted to idarubicinone, the aglycone of the FDA approved anthracycline idarubicin, through the judicious orchestration of Co- and Ru-catalyzed arene oxidation and arenophile-mediated dearomative hydroboration. Such a global functionalization strategy, a combination of site-selective arene and dearomative functionalization, provided the key anthracycline framework in five operations and enabled rapid and controlled access to idarubicinone.

File list (2)

Manuscript.pdf (758.20 KiB)

view on ChemRxiv • download file

SI.pdf (4.34 MiB)

view on ChemRxiv • download file 


\title{
Synthesis of Idarubicinone via Global Functionalization of Tetracene
}

\author{
David G. Dennis, Mikiko Okumura and David Sarlah*
}

Roger Adams Laboratory, Department of Chemistry, University of Illinois, Urbana, Illinois 61801, USA e-mail: sarlah@illinois.edu<smiles>CC(=O)C1(O)Oc2c(O)c3c(c(O)c2[C@H](O)O1)C(=O)c1ccccc1C3=O</smiles>
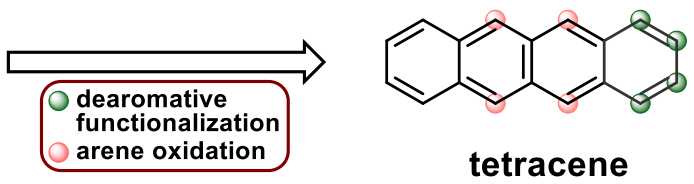

Anthracyclines are archetypal representatives of the tetracyclic type II polyketide natural products that are widely used in cancer chemotherapy. Although the synthesis of this class of compounds has been a subject to several investigations, all known approaches are based on annulations, relying on the union of properly prefunctionalized building blocks. In a conceptually different construct aimed at the synthesis of these important molecules, a readily available tetranuclear compound could be used as a starting template, ideally requiring only functional decorations to reach the desired target molecule. Herein, we describe the realization of this concept, providing a non-annulative strategy to anthracyclines from a polynuclear arene. Specifically, tetracene was converted to idarubicinone, the aglycone of the FDA approved anthracycline idarubicin, through the judicious orchestration of $\mathrm{Co}$ - and $\mathrm{Ru}$-catalyzed arene oxidation and arenophile-mediated dearomative hydroboration. Such a global functionalization strategy, a combination of site-selective arene and dearomative functionalization, provided the key anthracycline framework in five operations and enabled rapid and controlled access to idarubicinone. Finally, this design showcases the broader synthetic utility of long-underutilized simple polynuclear arenes as precursors for the synthesis of highly functionalized and stereochemically challenging products.

The Streptomyces-produced type II polyketides doxorubicin $(\mathbf{1})^{1}$ and daunorubicin $(\mathbf{2})^{2}$ are among the most effective and most often used chemotherapeutics due to their broad-spectrum of anticancer activity (Figure 1). ${ }^{3}$ For example, doxorubicin (1) is used for the treatment of breast and bladder cancers, childhood solid tumors, soft tissue sarcomas, and aggressive lymphomas. ${ }^{4}$ Similarly, daunorubicin (2) is primarily used as an antileukemic drug for multiple myeloma, acute myeloid leukemia, acute lymphocytic leukemia, and Kaposi's sarcoma. ${ }^{5}$ The antitumor activity of these agents is proposed to arise through several mechanisms, including the inhibition of DNA synthesis; DNA binding, cross-linking and alkylation; interference with DNA strand separation and helicase activity; topoisomerase-II-mediated DNA damage; and activation of apoptotic signaling pathways by reactive oxygen species. ${ }^{6}$ Although extremely effective, anthracyclines threaten patients with cumulative dose-dependent cardiotoxicity, severely limiting their long-term application as well as their use in patients with pre-existing cardiovascular risk. ${ }^{7}$ Therefore, significant research effort has been devoted to the identification of derivatives with improved pharmacological properties. ${ }^{8}$ The successful result of one such medicinal chemistry campaign is idarubicin (3), ${ }^{9}$ an FDA approved anticancer agent with superior therapeutic efficacy and reduced cardiotoxicity relative to daunorubicin (2). ${ }^{10}$

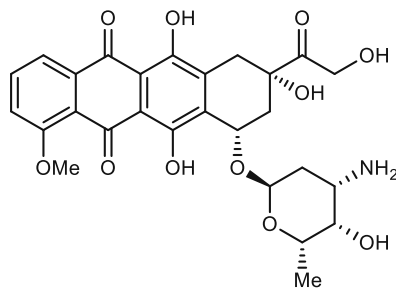

doxorubicin (1)

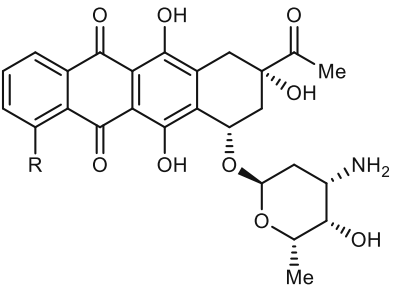

daunorubicin $(2, \mathrm{R}=\mathrm{OMe})$ idarubicin $(3, \mathrm{R}=\mathrm{H})$

Figure 1. Clinically-relevant anthracyclines. Doxorubicin (1), daunorubicin (2), and idarubicin (3) are the most commonly used anthracyclines for chemotherapy. 
Considering their clinical significance, the biosynthesis of anthracyclines has been a subject of intense research and proceeds through type II polyketide synthases. ${ }^{11}$ The hallmark of this remarkable biosynthetic machinery is the minimal set of iteratively used enzymes that work in concert, attaching ketide units to a carrier protein that serves as an anchor for the growing polyketide chain (Fig. 2a). For the anthracyclines, nine iterative decarboxylative Claisen condensations of malonyl-CoA to a starter propionyl-CoA unit form a decaketide, which undergoes a series of annulations, redox adjustments, glycosylation, and functionalizations to yield the final natural products. ${ }^{12}$ Despite having well-characterized biosynthetic gene clusters, daunorubicin (2) is the only anthracycline commercially produced by fermentation. Other anthracycline-producing strains are less efficient or give a mixture of products that cannot easily be separated. ${ }^{13}$ Nevertheless, 2 has served as an important starting point for the synthesis of numerous analogs and derivatives intended to improve cancer treatment, including the natural products doxorubicin (1) and idarubicin (3). Moreover, the need for tailored analogs has made anthracyclines the subject of rigorous investigation within the synthetic community. ${ }^{14-18}$ Thus, many innovative pathways to the aglycon anthracyclines (anthracyclinones) have been established, all of which rely upon annulation to forge one of the rings (see Fig 2b). The most commonly employed unifying disconnection is C-ring annulation, achieved through cycloadditions, ${ }^{19}$ cationic cyclizations, ${ }^{20}$ or anionic processes ${ }^{21}$ (Fig. 2b). Herein, we report a conceptually different, non-annulative approach to anthracyclinones, starting from a simple aromatic hydrocarbon via a global functionalization strategy (Fig. 2c). Specifically, idarubicinone (4) was synthesized from tetracene (6), an ideal aromatic precursor containing the essential tetracyclic framework. We envisioned that anthracyclinone $\mathbf{4}$ could be retrosynthetically traced back to $\mathbf{6}$ through a manifold of arene functionalizations $(\mathbf{6} \rightarrow \mathbf{5})$ and a site-selective dearomative elaboration $(\mathbf{5} \rightarrow \mathbf{4})$.

a
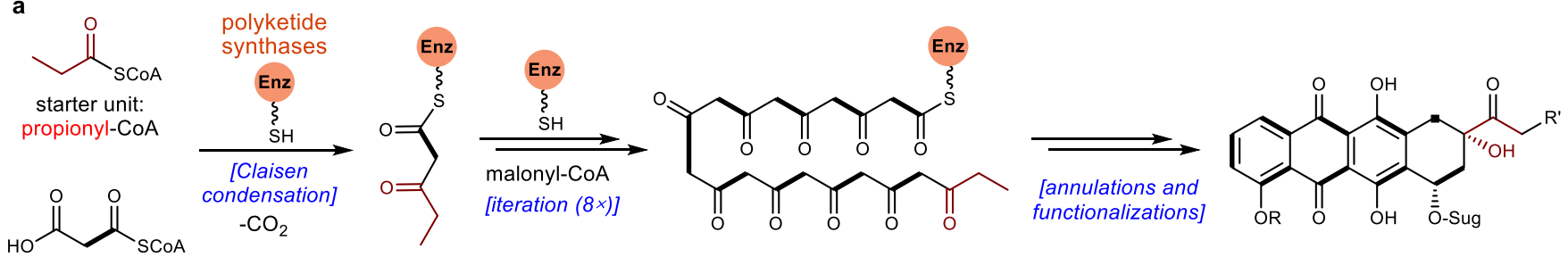

extender unit: malonyl-CoA

b

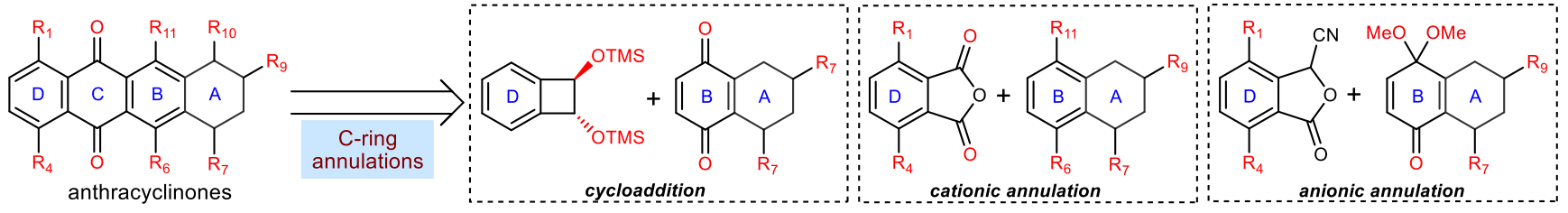

c

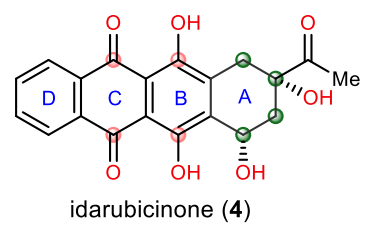

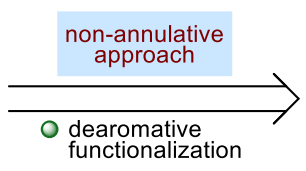

functionalization

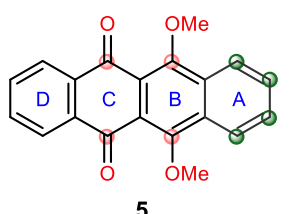

5

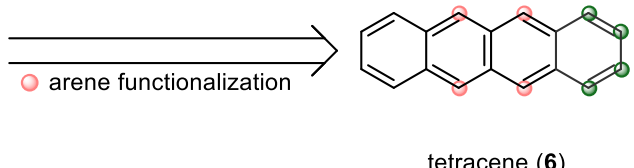

tetracene $(6)$

Figure 2. Synthesis of anthracyclines. a, Doxorubicin (1) and daunorubicin (2) are assembled by Type II polyketide synthases that condense a propionyl-CoA starter unit with nine malonyl-CoA extender units in an iterative fashion to form the polyketide backbone of these natural products. Each malonyl-CoA unit contributes a 2-carbon ketide unit (marked bold) to the growing polyketide chain. $\mathbf{b}$, Representative cycloaddition, cationic, and anionic synthetic approaches towards the aglycons of 1-3 using intermolecular C-ring annulation-based strategies. c, Synthesis of idarubicinone (4) through a non-annulative approach (this work). The anthracyclinone 4 was envisioned to derive from the simple polynuclear aromatic starting material tetracene (6) through a series of arene and dearomative functionalizations.

Following this global functionalization strategy, we commenced our studies by exploring functionalization reactions of tetracene $(\mathbf{5})$, which would establish the proper oxidation states of the internal $\mathrm{B}$ and $\mathrm{C}$ rings within idarubicinone (4) (Figure 3). Thus, inspired by a similar transformation reported on anthracene, ${ }^{22}$ we achieved the 
first oxidation of 5 with catalytic cobalt(II) tetraphenylporphyrin (CoTPP, 5 mol\%) and phenyliodine(III) sulfate as an oxidant, delivering 5,12-tetracenequinone (7) in 77\% yield. Although this transformation proceeded readily, the second oxidation to the corresponding 6,11-dihydroxy-5,12-tetracenequinone (5) proved more challenging. Several oxidants known for direct arene oxidation, such as CAN, Frémy's salt, hypervalent iodine reagents, or oxidizing metal complexes $^{23}$ were found to be unsuitable for this transformation. This setback was not surprising, as this type of perioxidation remains a largely unsolved synthetic challenge due to the high oxidation potential of quinones. Therefore, we decided to evaluate $\mathrm{C}-\mathrm{H}$ activation, anticipating that the quinone's carbonyls, would serve as weakly coordinating directing groups for the peri-(C-6) and (C-11) positions. ${ }^{24}$ After examining several carbonyl-directed hydroxylation protocols, developed a one-pot protocol involving a modification of $\mathrm{Ru}$-catalyzed $\mathrm{sp}^{2} \mathrm{C}-\mathrm{H}$ oxygenation pioneered by Ackermann ([Ru(cymene) $\left.\mathrm{Cl}_{2}\right]_{2}$ and PIFA) ${ }^{25}$ followed by sequential one-pot hydrolysis and methylation to give desired product 7. Control experiments revealed that this functionalization likely proceeds through the peri-selective formation of ruthenacycle intermediate I-1, delivering trifluoroacylphenol I-2, which underwent further oxidation to the hydroquinone stage in the presence of excess PIFA (see Supplementary Information for details). Finally, one-pot hydrolysis of trifluoroacetates and methylation of the resulting hydroquinone intermediate with $\mathrm{Me}_{2} \mathrm{SO}_{4}$ and base furnished the desired product $\mathbf{5}$.

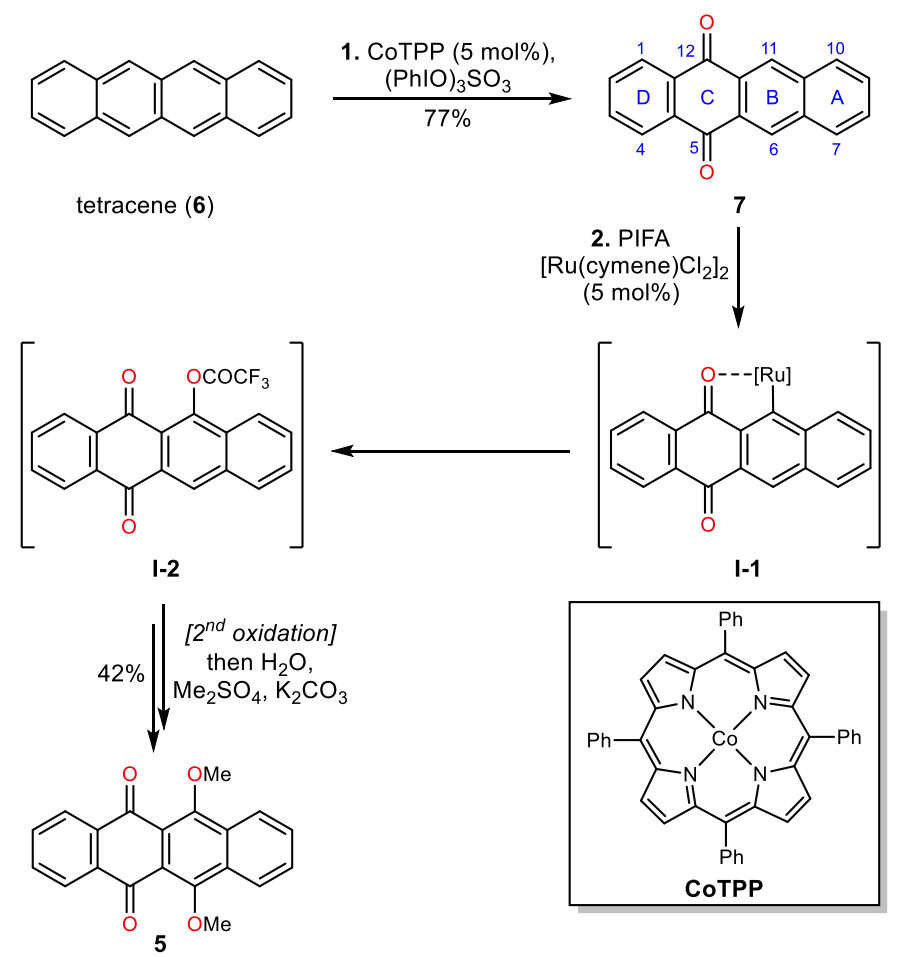

Figure 3. Two-fold oxidative functionalization of tetracene. Using Co- and Ru-catalyzed oxidations, tetracene was converted to the corresponding tetracenequinone derivative 5 . TPP $=5,10,15,20$-Tetraphenyl-21H,23H-porphine. cymene = isopropylbenzene

With arene oxidation completed, which set the required oxidation state of the $\mathrm{B}$ and $\mathrm{C}$ rings, we turned our attention to the dearomative functionalization of the terminal A ring (Fig. 4). We have recently reported a series of dearomatization strategies based on visible-light-promoted para-cycloaddition between arenes and arenophile $N$ methyl-1,2,4-triazoline-3,5-dione (MTAD) and subsequent in situ manipulation of the resulting cycloadducts. ${ }^{26-30}$ With polynuclear arenes, we consistently observed highly site-selective cycloadditions onto the terminal rings. Based upon these findings, the tetracenequinone derivative $\mathbf{5}$ contains two such regions, rings $\mathrm{A}$ and $\mathrm{D}$, amenable to cycloaddition with MTAD. However, the salient mechanistic feature of this process is a photoinduced charge- and electron-transfer from the arene to the arenophile ${ }^{26,31}$ therefore, the HOMO of the arene should dictate the regioselectivity in polynuclear aromatic settings. Accordingly, computational studies (at the B3LYP/def2-TZVPPD level of theory) of $\mathbf{5}$ predicted a strong bias for the A ring, which has profoundly larger HOMO orbital coefficients, (see Fig 4. for the corresponding HOMO surface). Indeed, this prediction correlated well with experiment, as we observed exclusive cycloaddition onto the desired A-ring. With this site-selective dearomatization, which provided the cycloadduct I-3, we explored several strategies to introduce the remaining two carbon atoms needed to complete 
the idarubicinone framework. We found that the arenophile-based cycloaddition in combination with in situ Rhcatalyzed alkene hydroboration $(\mathbf{5} \rightarrow[\mathbf{I}-\mathbf{3}] \rightarrow \mathbf{8})$ installed the boron moiety as a suitable handle for the introduction of an attached methyl ketone. Several hydroboration procedures were evaluated, but ultimately the cationic rhodium complex $\left[\mathrm{Rh}(\mathrm{cod})_{2} \mathrm{BF}_{4}\right]$ with 1,4-bis(diphenylphosphino)butane (dppb) and catecholborane provided the best outcome (for optimization details see Table S1 in Supplementary Information). ${ }^{32}$ While catecholborane was essential for the hydroboration step, the inherent instability of the resulting alkyl catechol boronic ester required immediate transesterification of catechol to pinacol to enable product isolation in higher yields. Importantly, using this protocol, we were able to prepare multigram quantities of organoborate $\mathbf{1 0}$ in a single pass in 55\% yield and 3:1 dr (see Fig. 4 for an X-ray of $\mathbf{8}$ ).
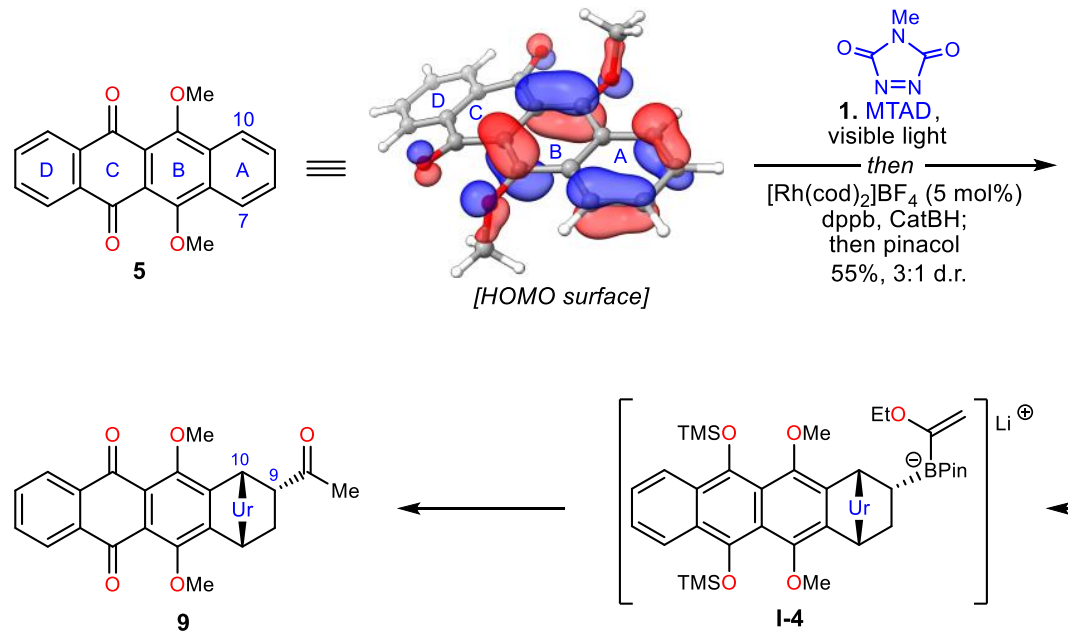

3. $\mathrm{KO} t \mathrm{Bu} ;$
then $\mathrm{Me}_{2} \mathrm{SO}_{4}$ $79 \%$<smiles>COc1c2c(c(OC)c3c1C(=O)C(C(C)=O)C[C@@H]3OC)C(=O)c1ccccc1C2=O</smiles>

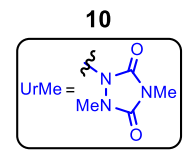

I-4
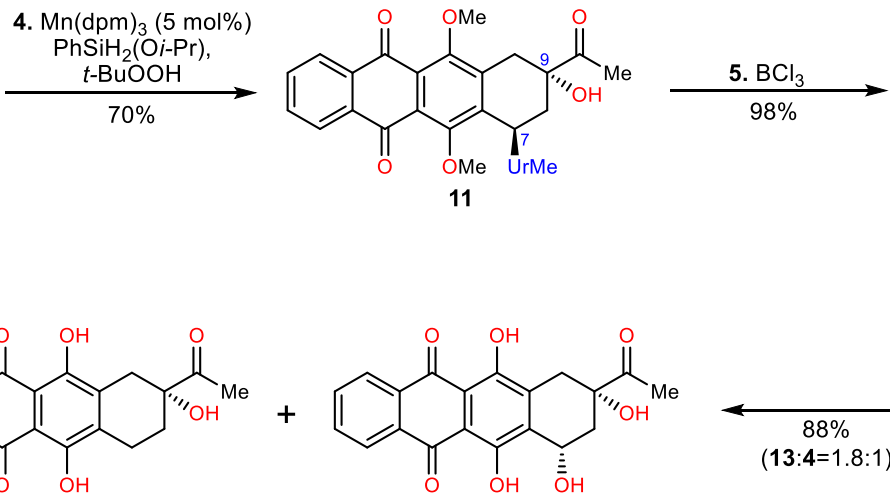

idarubicinone (4)
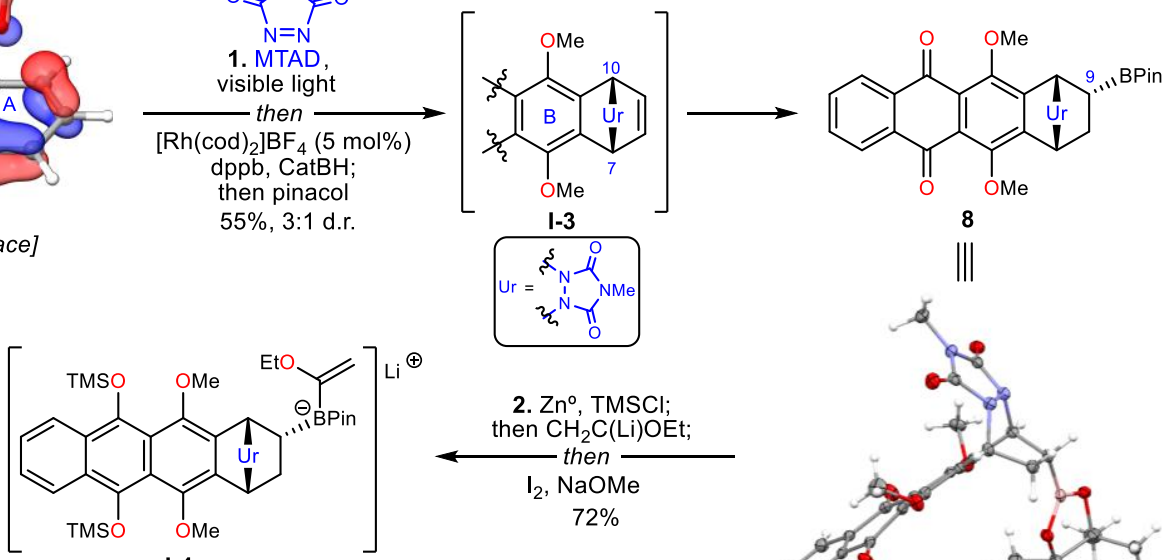

$72 \%$

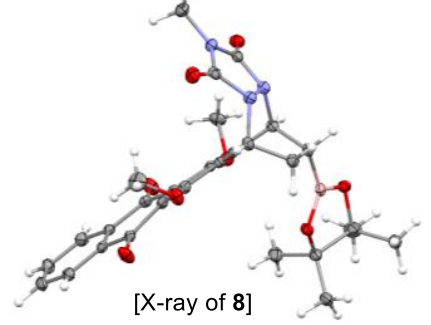<smiles>CC(=O)[C@]1(O)CCc2c(O)c3c(c(O)c2C1)C(=O)c1ccccc1C3=O</smiles>

7-deoxyidarubicinone (13)

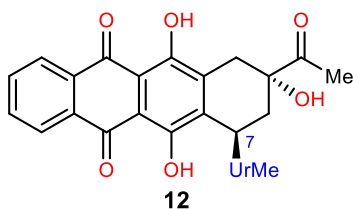

6. $\mathrm{Na}_{2} \mathrm{~S}_{2} \mathrm{O}_{4}$,
$\mathrm{NaOH}$, then $\mathrm{O}_{2}$

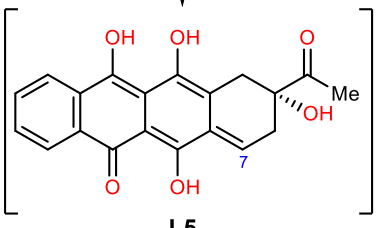

I-5

Ref 33.

Figure 4. Synthesis of idarubicinone (4). Tetracyclic derivative 5 underwent MTAD-mediated dearomative hydroboration and and Zweifel olefination to install appendant methyl ketone 9. Four additional operations, including Mukayama hydration $(\mathbf{1 0} \rightarrow \mathbf{1 1})$ and urazole to alcohol exchange via semiquinone methide I-5 delivered target compound 4. B3LYP/def2-TZVPPD level of theory was used for FMO calculations of 5 (isocontour at \pm 0.05 a.u.). MTAD, $N$-methyl-1,2,4-triazoline-3,5-dione; cod, 1,5cyclooctadiene; Cat, catechol; Pin, pinacol; dppb, bis(diphenylphosphino)butane (dppb); Ur, urazole; TMS, trimethylsilyl; dpm, tris(dipivaloylmethanato).

Elaboration of organoborate $\mathbf{8}$ to the full skeleton of idarubicinone required installation of a two-carbon fragment through a seemingly straightforward $B$-alkyl Suzuki coupling reaction. However, since several standard Pdand $\mathrm{Ni}$-catalyzed conditions failed, we decided to explore the $\mathrm{C}-\mathrm{C}$ bond forming strategies involving the rich chemistry of boron 1,2-metalate rearrangements. Particularly, we were keen to explore Zweifel olefination with lithiated ethoxyvinyl ether, ${ }^{35}$ which would provide rapid access to the appendant methyl ketone. Nevertheless, a major pitfall of this design was the presence of the quinone and its general incompatibility with organolithium reagents. Indeed, the prospecting experiments involving boronate $\mathbf{8}$ and 1-ethoxyvinyllithium resulted in the addition of organolithium species to quinone, delivering a mixture of products without any traces of the desired olefinated 
product. To address this chemoselectivity issue, we developed a one-pot process which involved in situ masking of the quinone. Thus, a THF solution of quinone boronate $\mathbf{8}$ was sonicated with Zn powder in the presence of TMSCl, resulting in the formation of a fully protected bis-hydroquinone. ${ }^{36}$ This intermediate was exposed to a freshly prepared lithiated ethyl vinyl ether to form the boronate complex I-4, which was immediately subjected to Zweifel protocol by addition of iodine and base. ${ }^{37}$ Concurrently with olefination, the excess iodine also oxidized the labile silylated hydroquinone back to the quinone, and workup of the reaction mixture with an aqueous $\mathrm{HCl}$ solution hydrolyzed the newly introduced vinyl ether to the corresponding methyl ketone 9. Remarkably, this one-pot operation involved several distinct transformations and was performed on a multigram scale with $72 \%$ yield.

While the arenophile-mediated dearomative hydroboration and subsequent Zweifel olefination introduced the desired methyl ketone, this sequence also installed a bridged urazole moiety, which had to be strategically transmuted to reveal the fully decorated A ring of idarubicinone (4). This task was partially accomplished by treatment of ketone 9 with base followed by $\mathrm{Me}_{2} \mathrm{SO}_{4}$, initiating $\beta$-elimination of urazole at position $\mathrm{C}$ - 10 with subsequent methylation of urazole hydrazyl nitrogen, furnishing $\alpha, \beta$-unsaturated ketone $\mathbf{1 0}$ in $79 \%$ yield. The $N$ alkylation of the urazole motif proved necessary to prevent undesired side reactions during subsequent manipulations (for details see Table S2 in Supplementary Information). Finally, subjecting olefin 10 to Mukaiyama hydration conditions $^{38}$ selectively introduced the tertiary alcohol at position C-9, as $\alpha$-ketol product $\mathbf{1 1}$ was obtained in $70 \%$ yield as a single diastereoisomer. Notably, the use of recently reported silane, $\mathrm{PhSiH}_{2}(\mathrm{OiPr}),{ }^{39}$ was beneficial for high conversions of this hydrogen-atom transfer process.

This hydration achieved the proper oxidation state of the A-ring, and the only difference between intermediate $\mathbf{1 1}$ and idarubicinone (4) at this stage resided in two hydroquinone protecting groups and the urazole moiety instead of a hydroxy group at C-7 position. While deprotection of methyl ethers to hydroquinone proceeded without any difficulties using $\mathrm{BCl}_{3}(\mathbf{1 1} \rightarrow \mathbf{1 2}, 98 \%$ yield), the removal of the urazole proved to be an arduous task. Eventually, the inspiration for the direct urazole-to-hydroxy exchange arrived from an older hypothesis for the biological mode of reactivity known as bioreductive alkylation. ${ }^{40}$ Thus, it was proposed that anthracyclines undergo in vivo quinone reduction and subsequent $\mathrm{C}-7$ amino sugar elimination, producing a reactive species in the form of a phenylogous quinone methide. ${ }^{41}$ Moreover, this concept was demonstrated in a bulk solution with several anthracyclines, which formed the corresponding semiquinone intermediates upon subjection to specific reducing agents. ${ }^{42,43}$ The direct translation of these findings to our system - for example the addition of sodium dithionite to precursor 12 - did not eliminate the urazole; however, after the addition of base $(\mathrm{NaOH})$ we observed elimination and exclusive formation of 7-deoxyidarubicinone (13) under anaerobic conditions. This result was in accordance with the literature, since deoxygenated anthracyclinones were commonly observed upon reduction of anthracyclines. Mechanistically, the reduction of quinone $\mathbf{1 2}$ to hydroquinone, followed by base-induced elimination of the urazole, likely formed the semiquinone methide $\mathbf{I - 5}$, which after protonation gave deaminated product $\mathbf{1 3}$. However, we noticed that in the presence of oxygen, this reactive intermediate underwent competitive oxidation, ${ }^{44}$ delivering idarubicinone $(\mathbf{I}-\mathbf{5} \rightarrow \mathbf{4})$. Accordingly, short exposure of $\mathbf{1 2}$ to an aqueous solution of sodium dithionite and $\mathrm{NaOH}$, followed by rapid saturation of reaction mixture with oxygen provided idarubicinone (4) and 7-deoxyidarubicinone (13) in $88 \%$ yield and 1:1.8 ratio. While extensive optimization of this protocol did not result in a higher ratio of desired anthracyclinone 4 to 13, this deoxygenated side-product could be readily converted to aglycone 4 in one or two steps using known protocols. ${ }^{45-48}$

In summary, we have described a functionalization-based approach to idarubicinone (4) from tetracene (5). The salient feature of this strategy is a judicious orchestration of two arene functionalizations and dearomatization, introducing functionality of A, B, and C rings of the anthracyclinone skeleton. Specifically, Co- and Ru-catalyzed arene oxidations, site-selective arenophile-mediated dearomative hydroboration, and subsequent Zweifel olefination provided the fully decorated anthracyclinone framework. Moreover, adjustment of the A ring, including a formally redox neutral urazole-to-hydroxy exchange delivered idarubicinone (4) in 8 operations from tetracene (6).

Importantly, by employing a simple polynuclear hydrocarbon aromatic starting material, the described work also presents a notable departure from previously reported syntheses of anthracyclinones in which annulations were requisite to overall synthetic design. In fact, polynuclear arenes are not commonly considered in synthetic planning for construction of stereochemically complex scaffolds. However, through the development of new methodologies, the present study provides a compelling case in which tetracene serves as an ideal template for imprinting of desired functionality. Thus, given the availability of a range of polynuclear arenes, as well as numerous functionalization 
opportunities, render this global functionalization approach an appealing and complementary entry for the preparation of other type II polyketide-like compounds.

\section{References}

1. Arcamone, F. et al. Adriamycin 14-hydroxydaunomycin, a new antitumor antibiotic from S. peucetius var. caesius. Biotechnol. Bioeng. 1969, 11, 1101-1110.

2. DiMarco, A. et al. Daunomycin, a New Antibiotic of the Rhodomycin Group. Nature 1964, 201, 706-707.

3. Arcamone, F. Antitumor anthracyclines: Recent developments. Med. Res. Rev. 1984, 4, 153-188.

4. Hortobagyi, G. N. Anthracyclines in the treatment of cancer. An overview. Drugs 1997, 54, (suppl. 4) 1-7.

5. Muggia, F. M.; Young, C. W.; Carter, S. K. Anthracycline Antibiotics in Cancer Therapy. (Developments in Oncology, 10). (Martinus Nijhoff Publishers, New York, 1982).

6. Cummings, J.; Anderson, L.; Willmott, N.; Smyth, J. F. The molecular pharmacology of doxorubicin in vivo. Eur. J. Cancer 1991, 27, 532-535.

7. Zucchi, R.; Danesi, R. Cardiac Toxicity of Antineoplastic Anthracyclines. Curr. Med. Chem.: Anti-Cancer Agents 2003, 3, 151-171.

8. Binaschi, M. et al. Anthracyclines: selected new developments. Curr. Med. Chem. Anti-Cancer Agents 2001, $1,113-130$.

9. Di Marco, A. et al. Synthesis and antitumor activity of 4-demethoxyadriamycin and 4-demethoxy-4'epiadriamycin. Cancer Treat. Rep. 1978, 62, 375-380.

10. Cersosimo, R. J. Idarubicin: an anthracycline antineoplastic agent. Clin. Pharm. 1992, 11, 152-167.

11. Hertweck, C.; Luzhetskyy, A.; Rebets, Y.; Bechthold, A. Type II Polyketide Synthases: Gaining a Deeper Insight into Enzymatic Teamwork. Nat. Prod. Rep. 2007, 24, 162-190.

12. Hutchinson, C.R. Biosynthetic Studies of Daunorubicin and Tetracenomycin C. Chem. Rev. 1997, 97, 25252536.

13. Malla, S.; Niraula, N. P.; Singh, B.; Liou, K.; Sohng, J. K. Limitations in doxorubicin production from Streptomyces peucetius. Microbiol. Res. 2010, 165, 427-435.

14. Krohn, K. Building Blocks for the Total Synthesis of Anthracyclinones, Prog. Chem. Org. Nat. Prod. 1989, $55,37-88$.

15. Krohn, K. Synthesis of anthracyclinones by electrophilic and nucleophilic addition to anthraquinones. Tetrahedron 1990, 46, 291-318.

16. Thomas, G. J. Recent Progress in the Chemical Synthesis of Antibiotics: Synthesis of Anthracyclines Related to Daunomycin pp 467-496. (Springer-Verlag, New York, 1990).

17. Wheeler, D. M. S.; Wheeler, M. M. Studies in Natural Products Chemistry: Stereoselective Syntheses of Doxorubicin and Related Compounds Vol. 14 (Elsevier: Amsterdam, 1994).

18. Achmatowicz, O.; Szechner, B. Synthesis of Enantiomerically Pure Anthracyclinones. Top. Curr. Chem. 2007, 282, 143-186.

19. Allen, J. G.; Hentemann, M. F.; Danishefsky, S. J. A Powerful O-Quinone Dimethide Strategy for Intermolecular Diels-Alder Cycloadditions J. Am. Chem. Soc. 2000, 122, 571-575.

20. Ishizumi, K.; Ohashi, N.; Tanno, N. Stereospecific total synthesis of 9-aminoanthracyclines: (+)-9-amino-9deoxydaunomycin and related compounds J. Org. Chem. 1987, 52, 4477-4485.

21. Swenton, J. S.; Freskos, J. N.; Morrow, G. W.; Sercel, A. D. A convergent synthesis of (+)-4demethoxydaunomycinone and (+)-daunomycinone. Tetrahedron 1984, 40, 4625-4632.

22. Geraskin, I. M. et al. Comparative Reactivity of Hypervalent Iodine Oxidants in Metalloporphyrin-Catalyzed Oxygenation of Hydrocarbons: Iodosylbenzene Sulfate and 2-Iodylbenzoic Acid Ester as Safe and Convenient Alternatives to Iodosylbenzene Adv. Synth. Catal. 2009, 351, 733-737.

23. Dudfield, P. J. Synthesis of quinones. In Comprehensive Organic Synthesis (Ley, S. V., Ed.), Vol. 7, 345-356 (Pergamon Press, Oxford, 1991).

24. Engle, K. M.; Mei, T.-S.; Wasa, M.; Yu, J.-Q. Weak Coordination as a Powerful Means for Developing Broadly Useful C-H Functionalization Reactions. Acc. Chem. Res. 2012, 45, 788-802.

25. Thirunavukkarasu, V. S.; Ackermann, L. Ruthenium-Catalyzed C-H Bond Oxygenations with Weakly Coordinating Ketones. Org. Lett. 2012, 14, 6206-6209.

26. Southgate, E. H.; Pospech, J.; Fu, J.; Holycross, D. R.; Sarlah, D. Dearomative Dihydroxylation with Arenophiles. Nat. Chem. 2016, 8, 922-928.

27. Okumura, M.; Nakamata Huynh; S. M.; Pospech, J.; Sarlah, D. Arenophile-mediated Dearomative Reduction. Angew. Chem., Int. Ed. 2016, 55, 15910-15914. 
28. Okumura, M.; Shved, A. S.; Sarlah, D. Palladium-Catalyzed Dearomative syn-1,4-Carboamination. J. Am. Chem. Soc. 2017, 139, 17787-17790.

29. Hernandez, L. W.; Klöckner, U.; Pospech, J.; Hauss, L.; Sarlah, D. Nickel-Catalyzed Dearomative trans-1,2Carboamination. J. Am. Chem. Soc. 2018, 140, 4503-4507.

30. Wertjes, W. C.; Okumura, M.; Sarlah, D. Palladium-Catalyzed Dearomative syn-1,4-Carboamination. J. Am. Chem. Soc. 2019, 141, 163-167.

31. Kjell, D. P.; Sheridan, R. S. A photochemical Diels-Alder reaction of N-methyltriazolinedione. J. Photochem. 1985, 28, 205-214.

32. Evans, D. A.; Fu, G. C.; Hoveyda, A. H. Rhodium(I)- and iridium(I)-catalyzed hydroboration reactions: scope and synthetic applications. J. Am. Chem. Soc. 1992, 114, 6671-6679.

33. Chemler, S. R.; Trauner, D.; Danishefsky, S. J. The B-Alkyl Suzuki-Miyaura Cross-Coupling Reaction: Development, Mechanistic Study, and Applications in Natural Product Synthesis. Angew. Chem., Int. Ed. 2011, 40, 4544-4568.

34. Cherney, A. H.; Kadunce, N. T.; Reisman, S. E. Enantioselective and Enantiospecific Transition-MetalCatalyzed Cross-Coupling Reactions of Organometallic Reagents To Construct C-C Bonds. Chem. Rev. 2015, $115,9587-9652$.

35. Zweifel, G.; Arzoumanian, H.; Whitney, C. C. A Convenient Stereoselective Synthesis of Substituted Alkenes via Hydroboration-Iodination of Alkynes. J. Am. Chem. Soc. 1967, 89, 3652-3653.

36. Rasmussen, J. K.; Krepski, L. R.; Heilmann, S. M.; Smith, H. K.; Tumey, M. L. A Convenient Synthesis of 1,2-Bis[trimethylsiloxy]alkenes from $\alpha$-Diketones. Synthesis 1983, 457-595.

37. Sonawane, R. P.; Jheengut, V.; Rabalakos, C.; Larouche-Gauthier, R.; Scott, H. K.; Aggarwal, V. K. Enantioselective Construction of Quaternary Stereogenic Centers from Tertiary Boronic Esters: Methodology and Applications. Angew. Chem., Int. Ed. 2011, 50, 3760-3763.

38. Isayama, S.; Mukaiyama, T. A New Method for Preparation of Alcohols from Olefins with Molecular Oxygen and Phenylsilane by the Use of Bis(acetylacetonato)cobalt(II). Chem. Lett. 1989, 18, 1071-1074.

39. Obradors, C. L.; Martinez, R. M.; Shenvi, R. A. Ph(i-PrO)SiH 2 : An Exceptional Reductant for MetalCatalyzed Hydrogen Atom Transfers. J. Am. Chem. Soc. 2016, 138, 4962-4971.

40. Moore, H. W. Bioactivation as a model for drug design bioreductive alkylation. Science 1977, 197, $527-532$.

41. Moore, H. W.; Czerniak, R. Naturally occurring quinones as potential bioreductive alkylating agents. Med. Res. Rev. 1981, 1, 249-280.

42. Gaudiano, G.; Frigerio, M.; Bravo, P.; Koch, T. H. Reduction of daunomycin in dimethyl sulfoxide. Longlived semiquinones and quinone methide and formation of an enolate at the 14-position via the quinone methide. J. Am. Chem. Soc. 1992, 114, 3107-3113.

43. Gaudiano, G.; Frigerio, M.; Sangsurasak, C.; Bravo, P.; Koch, T. H. Reduction of daunomycin and 11deoxydaunomycin with sodium dithionite in DMSO. Formation of quinone methide sulfite adducts and the first NMR characterization of an anthracycline quinone methide. J. Am. Chem. Soc. 1992, 114, 5546-5553.

44. Gaudiano, G.; Koch, T. H. Reaction of the quinonemethide from reductive glycosidic cleavage of daunomycin with molecular oxygen. Evidence for semiquinonemethide formation. J. Am. Chem. Soc. 1990, 112, 25, 94239425.

45. Kende, A. S.; Tsay, Y.-G.; Mills, J. E. Total synthesis of ( \pm )-daunomycinone and ( \pm )-carminomycinone. $J$. Am. Chem. Soc. 1976, 98, 1967-1969.

46. Wong, C. M.; Schwenk, R.; Popien, D.; Ho, T. L. The Total Synthesis of Daunomycinone. Can. J. Chem. 1973, 51, 466-467.

47. Smith, T. H.; Fujiwara, A. N.; Lee, W. W.; Wu, H. Y.; Henry, D. W. Synthetic approaches to adriamycin. 2. Degradation of daunorubicin to a nonasymmetric tetracyclic ketone and refunctionalization of the A ring to adriamycin. J. Org. Chem. 1977, 42, 3653-3660.

48. Kimball, S. D; Walt, D. R.; Johnson, F. Anthracyclines and related substances. 3. Regiospecific total synthesis of 11-deoxydaunomycinone. J. Am. Chem. Soc. 1981, 103, 1561-1563.

\section{Acknowledgements}

Financial support for this work was provided by the University of Illinois, the NIH/National Institute of General Medical Sciences (R01 GM122891), and the donors of the American Chemical Society Petroleum Research Fund (PRF\#57175-DNI1). D.S. is an Alfred P. Sloan Fellow. M.O. thanks the Honjo International Scholarship Foundation. Solvias AG is acknowledged for a generous gift of chiral ligands. We also thank Dr. D. Olson and Dr. L. Zhu for 
NMR spectroscopic assistance, Dr. D. L. Gray and Dr. T. Woods for X-ray crystallographic analysis assistance, and F. Sun for mass spectrometric assistance. 


\title{
Synthesis of Idarubicinone via Global Functionalization of Tetracene
}

\author{
David G. Dennis, Mikiko Okumura and David Sarlah* \\ Roger Adams Laboratory, Department of Chemistry, University of Illinois, Urbana, IL 61801, \\ USA.
}

\section{Table of Contents}

I. General Procedures 2

II. Experimental Section 3

- Model Studies (Supplementary Table S1) 3

- Synthesis of alcohol S5 and boronic ester S6 3

- Synthesis of tetracene quinone 7

- Synthesis of tetracene derivative 5

- $\quad$ Synthesis of tetracene derivative S7 6

- Synthesis of boronic ester $\mathbf{8}$ via dearomative hydroboration 7

- Images of experimental setup (Supplementary Photo S1) 8

- Synthesis of ketone 9 via Zweifel Olefination 8

- Synthesis of enone $\mathbf{1 0} 10$

- The influence of N-substitution on Mukaiyama hydration (Supplementary Table S2) 11

- Synthesis of $\alpha$-ketol 11 via Mukaiyama hydration 11

- Preparation of $\alpha$-ketol $12 \quad 12$

- Optimization of final transformation of hydroquinone 12 (Supplementary Table S3) 13

- Preparation of idarubicinone (4) and 7-deoxyidarubicinone (13) 13

- Images of experimental setup (Supplementary Photo S2) 15

III. References 15

$\begin{array}{lll} & \text { IV. } & { }^{1} \mathrm{H} \text { NMR and }{ }^{13} \mathrm{C} \text { NMR Spectra }\end{array}$

V. Crystallographic Data $\quad 41$ 


\section{General Procedures}

All reactions were performed under a nitrogen atmosphere in oven- or heat-gun-dried glassware unless otherwise indicated. Anhydrous dichloromethane and tetrahydrofuran were purified using the MBSPS solvent purification system containing activated alumina manufactured by MBRAUN. $\left[\mathrm{Rh}(\mathrm{cod})_{2}\right] \mathrm{BF}_{4}$ was prepared following known proceedrue ${ }^{1}$ from $[\mathrm{Rh}(\operatorname{cod}) \mathrm{Cl}]_{2}$. Pinacol hexahydrate was dried before use by azeotropic distillation with benzene followed by recrystallizing from benzene. ${ }^{2} \mathrm{~N}$-Methyl-1,2,4triazoline-3,5-dione (MTAD) was prepared based on literature procedures. ${ }^{3,4}$ Catechol borane (HBcat) was prepared in two steps from catechol, boric acid, and borane dimethyl sulfide following literature proceedures. $^{5}$ Tris(2,2,6,6-tetramethyl-3,5-heptanedionato)manganese(III) ( $\left.\mathrm{Mn}(\mathrm{dpm})_{3}\right)$ was purchased from Strem Chemicals. Isopropoxy(phenyl)silane $\left(\mathrm{Ph}(i \mathrm{PrO}) \mathrm{SiH}_{2}\right)$ was prepared from phenylsilane $\left(\mathrm{PhSiH}_{3}\right)$ according to reported procedure. ${ }^{6}$ Reaction temperatures correspond to the external temperature of the reaction vessel unless otherwise stated. Reactions were monitored by thin-layer chromatography (TLC) using $0.25 \mathrm{~mm}$ Macherey-Nagel silica gel plates (SIL G-25 UV 254 ). Plates were visualized by UV and visible light. Silicycle SiliaFlash ${ }^{\circledR} \mathrm{P} 60\left(\mathrm{SiO}_{2}, 40-63 \mu \mathrm{m}\right.$ particle size, 230-400 mesh) was used for flash column chromatography.

${ }^{1} \mathrm{H}$ NMR spectra were obtained at $500 \mathrm{MHz}$ and ${ }^{13} \mathrm{C}$ NMR were obtained at $126 \mathrm{MHz}$. NMR spectra were recorded using a Bruker $500 \mathrm{MHz}$ spectrometer and were referenced to residual chloroform (7.26 ppm, $\left.{ }^{1} \mathrm{H} ; 77.0 \mathrm{ppm},{ }^{13} \mathrm{C}\right)$ or residual deuterated dimethylsulfoxide $\left(2.50 \mathrm{ppm},{ }^{1} \mathrm{H} ; 35.92 \mathrm{ppm},{ }^{13} \mathrm{C}\right)$. Chemical shifts are reported in parts per million (ppm) and multiplicities are as indicated: $s$ (singlet), $\mathrm{d}$ (doublet), $\mathrm{t}$ (triplet), q (quartet), m (multiplet), and br (broad). Coupling constants, J, are reported in Hertz (Hz). High resolution mass spectrometry (HRMS) data were collected by the University of Illinois Mass Spectrometry Laboratory using electrospray ionization $\left(\mathrm{ESI}^{+}\right)$and a time-of-flight (TOF) mass analyzer. Data are reported in the form of $\mathrm{m} / \mathrm{z}$. Infrared (IR) spectra were measured neat on a Perkin-Elmer Spectrum Two FT-IR spectrometer. Peaks are reported in $\mathrm{cm}^{-1}$ with indicated relative intensities: s (strong, 0-33\% $\mathrm{T}$ ); $\mathrm{m}$ (medium, 34-66\% T), w (weak, 67-100\% T), and br (broad). Melting points were measured on a Buchi B540 melting point apparatus and are uncorrected. The x-ray diffraction experiments were conducted using Bruker D8 Venture/Photon 100 diffractometer or Bruker APEX-II CCD diffractometer. Using Olex2, ${ }^{7}$ the structures were solved with ShelXT ${ }^{8}$ structure solution program using the intrinsic phasing solution method, and the XL refinement package using least squares minimization. 


\section{Experimental Section}

\section{Model Studies: Arenophile-Assisted Dearomative Hydroboration}

Table S1: Optimization of MTAD-mediated dearomative hydroboration:

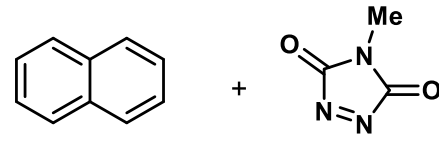

$\mathbf{S 1}(2.0 \mathrm{eq})$

MTAD

(S2, 1.0 eq)

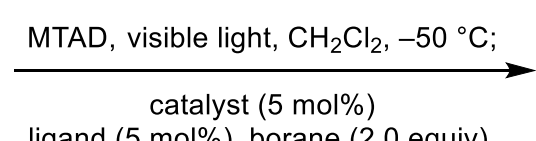

ligand ( $5 \mathrm{~mol} \%)$, borane (2.0 equiv)

solvent; then $\mathrm{NaBO}_{3} \cdot 4 \mathrm{H}_{2} \mathrm{O}$

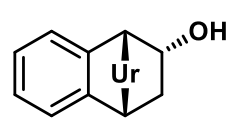

S5

\begin{tabular}{|c|c|c|c|c|c|c|}
\hline entry & catalyst & borane & solvent & ligand & additive & yield \\
\hline 1 & $\mathrm{CuCl}$ & $\mathrm{B}_{2} \mathrm{pin}_{2}$ & THF & dppp & $\mathrm{LiO} t \mathrm{Bu} / \mathrm{MeOH}$ & $<5 \%$ \\
\hline 2 & $\mathrm{CuCl}$ & $\mathrm{B}_{2} \mathrm{pin}_{2}$ & Toluene & IMes & $\mathrm{KOtBu} / \mathrm{MeOH}$ & $<5 \%$ \\
\hline 3 & $\mathrm{CuCl}$ & $\mathrm{B}_{2} \mathrm{pin}_{2}$ & Toluene & $\mathrm{IPr}$ & $\mathrm{KO} t \mathrm{Bu} / \mathrm{MeOH}$ & $<5 \%$ \\
\hline 4 & {$[\mathrm{Rh}(\mathrm{COD}) \mathrm{Cl}]_{2}$} & HBcat & THF & dppp & - & $15 \%$ \\
\hline 5 & {$[\mathrm{Rh}(\mathrm{COD}) \mathrm{Cl}]_{2}$} & HBcat & THF & $\mathrm{dppb}$ & - & $25 \%$ \\
\hline 6 & {$[\mathrm{Rh}(\mathrm{COD}) \mathrm{Cl}]_{2}$} & HBpin & THF & dppb & - & $<5 \%$ \\
\hline 7 & {$[\mathrm{Rh}(\mathrm{COD}) \mathrm{Cl}]_{2}$} & HBcat & THF & $\mathrm{dppb}$ & $\mathrm{AgBF}_{4}$ & $30 \%$ \\
\hline 8 & {$[\mathrm{Rh}(\mathrm{COD}) \mathrm{Cl}]_{2}$} & HBcat & THF & $\mathrm{dppb}$ & AgOTf & $<5 \%$ \\
\hline 9 & {$\left[\mathrm{Rh}(\mathrm{COD})_{2}\right] \mathrm{BF}_{4}$} & HBcat & THF & $\mathrm{dppb}$ & - & $52 \%$ \\
\hline $10^{a}$ & {$\left[\mathrm{Rh}(\mathrm{COD})_{2}\right] \mathrm{BF}_{4}$} & HBcat & THF & $\mathrm{dppb}$ & - & $73 \%$ \\
\hline
\end{tabular}

a. $10 \mathrm{~mol} \%$ catalyst and ligand used.

Synthesis of alcohol S5 and boronic ester S6:<smiles>c1ccc2ccccc2c1</smiles>

S1

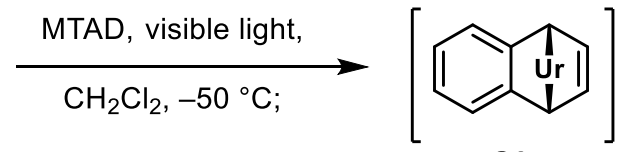

S3

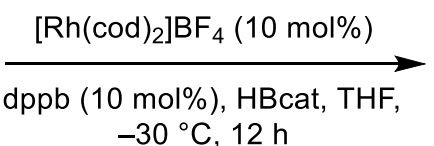

$-30{ }^{\circ} \mathrm{C}, 12 \mathrm{~h}$<smiles>Cl[C@H]1CC2C[C@@H](Br)C1c1ccccc12</smiles>

S4

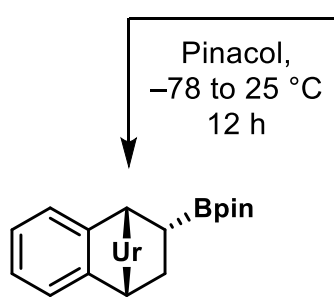

S6

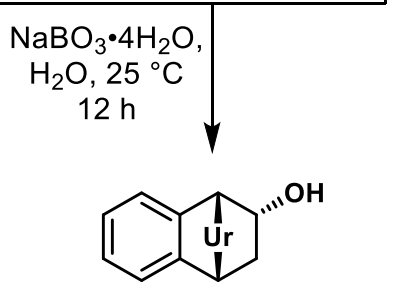

S5

Naphthalene (S1, $113.3 \mathrm{mg}, 0.88 \mathrm{mmol}, 2.0$ equiv.) and MTAD (S2, $50.0 \mathrm{mg}, 0.44 \mathrm{mmol}, 1.0$ equiv.) were added to the test tube, which was sealed with a septum and evacuated/purged with nitrogen gas three times. Then $\mathrm{CH}_{2} \mathrm{Cl}_{2}(4.4 \mathrm{~mL}, 0.10 \mathrm{M})$ was added, the reaction mixture was cooled to $-50{ }^{\circ} \mathrm{C}$, and irradiated with visible light. Upon decolorization, LED lights were turned off and THF (4.4 mL, 0.10 M) was added 
followed by a solution of $\left[\mathrm{Rh}(\operatorname{cod})_{2}\right] \mathrm{BF}_{4}(18.0 \mathrm{mg}, 44 \mu \mathrm{mol}, 10 \mathrm{~mol} \%)$ and dppb (18.9 mg, $44 \mu \mathrm{mol}, 10$ mol\%) in $\mathrm{CH}_{2} \mathrm{Cl}_{2}(0.5 \mathrm{~mL})$. HBcat $(95 \mu \mathrm{L}, 0.88 \mathrm{mmol}, 2.0$ equiv.) was added in a dropwise fashion, and the temperature was adjusted to $-30{ }^{\circ} \mathrm{C}$ for $12 \mathrm{~h}$, resulting in the formation of $\mathbf{S 4}$. Catechol ester $\mathbf{S} \mathbf{4}$ could be oxidized with sodium perborate tetrahydrate to give the corresponding alcohol S5 by preparing a suspension of $\mathrm{NaBO}_{3} \cdot 4 \mathrm{H}_{2} \mathrm{O}\left(680.3 \mathrm{mg}, 4.4 \mathrm{mmol}, 10\right.$ equiv.) in $\mathrm{H}_{2} \mathrm{O}(8.8 \mathrm{~mL})$, and directly adding the entire reaction mixture to the suspension, followed by $12 \mathrm{~h}$ of vigorous stirring. The reaction was then extracted with EtOAc, dried over $\mathrm{MgSO}_{4}$, and concentrated under reduced pressure. Purification via flash chromatography $\left(\mathrm{SiO}_{2}\right.$, EtOAc:hexanes = 1:2) afforded the alcohol $\mathbf{S 5}$ as a white solid (84.2 $\mathrm{mg}, 0.32$ mmol, $73 \%)$.

mp: $219.4-220.2^{\circ} \mathrm{C}$

$\mathbf{R}_{\mathbf{f}}=0.16($ EtOAc:hexanes, $1: 2 \mathrm{v} / \mathrm{v})$ :

${ }^{1} \mathbf{H}$ NMR $\left(500 \mathrm{MHz}, \mathrm{CDCl}_{3}\right): \delta 7.35$ - $7.43(\mathrm{~m}, 3 \mathrm{H}), 7.29$ - $7.33(\mathrm{~m}, 1 \mathrm{H}), 5.25$ - $5.28(\mathrm{~m}, 2 \mathrm{H}), 4.59$ - 4.64 (m, 1H), $2.80-2.86(\mathrm{~m}, 4 \mathrm{H}), 1.96(\mathrm{br}, 1 \mathrm{H}), 1.49(\mathrm{ddd}, \mathrm{J}=14.0,3.8,1.8 \mathrm{~Hz}, 1 \mathrm{H})$

${ }^{13}$ C NMR $\left(126 \mathrm{MHz}, \mathrm{CDCl}_{3}\right): \delta 156.86,156.61,135.08,130.88,129.71,129.24,126.89,123.47,65.04$, $58.32,53.26,36.52,25.54$

IR (ATR, cm ${ }^{-1}$ ): 2947 (w), 2931 (w), 1768 (m), 1701 (s), 1461 (s), 1396 (w), 1091 (w), 759 (m), 548 (m)

HRMS (m/z): $[\mathrm{M}+\mathrm{H}]^{+}$calcd. for $\mathrm{C}_{13} \mathrm{H}_{14} \mathrm{~N}_{3} \mathrm{O}_{3}, 260.1035$; found, 260.1036.

Alternatively, a solution of pinacol in THF ( $440 \mu \mathrm{L}, 2 \mathrm{M}, 2.0$ equiv.) was added to the reaction mixture containing $\mathbf{S 4}$ at $-30{ }^{\circ} \mathrm{C}$ and the solution was warmed to room temperature slowly over the course of $12 \mathrm{~h}$. The mixture was diluted with saturated $\mathrm{NaCl}$, extracted with EtOAc, combined organic phases dried over $\mathrm{MgSO}_{4}$, and concentrated under reduced pressure. Purification via flash chromatography $\left(\mathrm{SiO}_{2}\right.$, $\mathrm{Et}_{2} \mathrm{O}$ :hexanes = 1:4) afforded the boronic ester $\mathbf{S 6}$ as a white solid (120 mg, $\left.0.32 \mathrm{mmol}, 72 \%\right)$, which was readily crystallized from $\mathrm{Et}_{2} \mathrm{O}$.

mp: $148.7-150.0^{\circ} \mathrm{C}$

$\mathbf{R}_{\mathbf{f}}=0.56($ EtOAc:hexanes, $1: 2 \mathrm{v} / \mathrm{v})$

${ }^{1} \mathbf{H}$ NMR $\left(500 \mathrm{MHz}, \mathrm{CDCl}_{3}\right): \delta 7.23-7.32(\mathrm{~m}, 4 \mathrm{H}), 5.43(\mathrm{~d}, \mathrm{~J}=2.8 \mathrm{~Hz}, 1 \mathrm{H}), 5.28(\mathrm{dd}, \mathrm{J}=3.1,2.6 \mathrm{~Hz}$, 1H), $2.83(\mathrm{~s}, 3 \mathrm{H}), 2.47$ (ddd, J = 13.3, 10.6, 3.1 Hz, 1H), 2.11 (ddd, J = 10.6, 4.9, $2.8 \mathrm{~Hz}, 1 \mathrm{H}), 1.82$ (ddd, J $=13.3,4.9,2.6 \mathrm{~Hz}, 1 \mathrm{H}), 1.04(\mathrm{~s}, 6 \mathrm{H}), 0.98(\mathrm{~s}, 6 \mathrm{H})$

${ }^{13} \mathrm{C}$ NMR $\left(126 \mathrm{MHz}, \mathrm{CDCl}_{3}\right): \delta 157.08,156.74,135.29,134.83,128.72,128.32,124.27,123.44,84.05$, $55.43,54.22,26.07,25.29,24.77,24.64,20.46$

IR (ATR, cm ${ }^{-1}$ ): 2978 (w), 1769 (w), 1710 (s), 1452 (m), 1372 (m), 1332 (m), 1141 (m)

HRMS (m/z): $[\mathrm{M}+\mathrm{H}]^{+}$calcd. for $\mathrm{C}_{19} \mathrm{H}_{25} \mathrm{~N}_{3} \mathrm{O}_{4} \mathrm{~B}, 370.1938$; found, 370.1935. 
Synthesis of tetracenequinone 7 :<smiles>c1ccc2cc3cc4ccccc4cc3cc2c1</smiles>

tetracene (6)

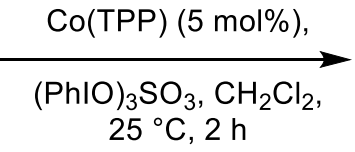

$25^{\circ} \mathrm{C}, 2 \mathrm{~h}$

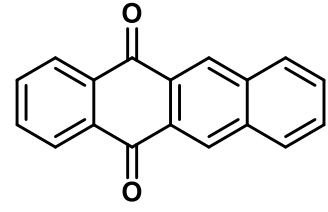

7

Tetracene (6, $200.0 \mathrm{mg}, 876 \mu \mathrm{mol}, 1.0$ equiv.), cobalt tetraphenylporphyrin (CoTPP, $29.4 \mathrm{mg}, 43.8 \mu \mathrm{mol}$, $5 \mathrm{~mol} \%$ ), and ( $\mathrm{PhIO})_{3} \mathrm{SO}_{3}(1.62 \mathrm{~g}, 2.19 \mathrm{mmol}, 2.5$ equiv.) were combined in a round-bottom flask and purged with nitrogen. Then $\mathrm{CH}_{2} \mathrm{Cl}_{2}(29.2 \mathrm{~mL}, 0.03 \mathrm{M})$ was added and the mixture was stirred at $25{ }^{\circ} \mathrm{C}$ for $2 \mathrm{~h}$. The resulting dark solution was filtered through a pad of silica gel using ethyl acetate as an eluent, and the solvent was removed in vacuo. The crude yellow-orange solid was purified via flash chromatography $\left(\mathrm{SiO}_{2}, \mathrm{CH}_{2} \mathrm{Cl}_{2}\right.$ :hexanes $\left.=7: 3\right)$ to afford the title compound 7 as a yellow-orange solid $(173.4 \mathrm{mg}, 670 \mu \mathrm{mol}$, $77 \%$ ). All spectroscopic data were consistent with those previously reported for this compound. ${ }^{9}$

Synthesis of tetracene derivative $\mathbf{5}$ :<smiles>O=C1c2ccccc2C(=O)c2cc3ccccc3cc21</smiles>

7

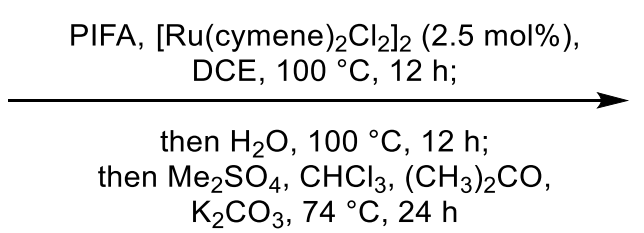

$\mathrm{K}_{2} \mathrm{CO}_{3}, 74{ }^{\circ} \mathrm{C}, 24 \mathrm{~h}$

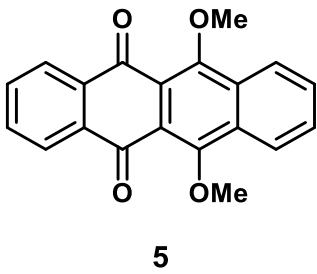

5

Tetracenequinone (7, $250.0 \mathrm{mg}, 967 \mu \mathrm{mol}, 1.0$ equiv.), [Ru(p-cymene) $\left.\mathrm{Cl}_{2}\right]_{2}(14.8 \mathrm{mg}, 24.2 \mu \mathrm{mol}, 2.5$ mol\%), and [bis(trifluoroacetoxy)iodo]benzene (PIFA, $1.04 \mathrm{~g}, 2.42 \mu \mathrm{mol}, 2.5$ equiv.) were combined in a vial and purged with nitrogen. Dichloroethane (DCE, $390 \mu \mathrm{L}, 2.5 \mathrm{M}$ ) was added and the vial was heated to $100{ }^{\circ} \mathrm{C}$ for $12 \mathrm{~h}$. After cooling the resulting purple solution to room temperature, the reaction was charged with $\mathrm{H}_{2} \mathrm{O}$ (349 $\mu \mathrm{L}, 19.36 \mathrm{mmol}, 20$ equiv.) and heated to $100{ }^{\circ} \mathrm{C}$ for $12 \mathrm{~h}$. After cooling the mixture to room temperature, the solvents were removed under reduced pressure, and potassium carbonate $\left(\mathrm{K}_{2} \mathrm{CO}_{3}, 2.68 \mathrm{~g}\right.$, $19.36 \mathrm{mmol}, 20$ equiv.) was added to the dark red gum. The mixture was purged with $\mathrm{N}_{2}$ for 30 min followed by addition of acetone $(4.8 \mathrm{~mL})$, chloroform $(4.8 \mathrm{~mL})$, and dimethyl sulfate $(1.85 \mathrm{~mL}, 19.36 \mathrm{mmol}, 20$ equiv.). The resulting reaction was then heated to $74{ }^{\circ} \mathrm{C}$ for $24 \mathrm{~h}$. After cooling, the orange solution was filtered, the insoluble residue was washed with $\mathrm{CH}_{2} \mathrm{Cl}_{2}$, and the solvent was removed under reduced pressure. The crude orange solid was purified via flash chromatography $\left(\mathrm{SiO}_{2}, \mathrm{CH}_{2} \mathrm{Cl}_{2}\right.$ :hexanes $\left.=7: 3\right)$ to afford the title compound as a yellow solid (118.6 mg, $407 \mu \mathrm{mol}, 42 \%)$.

mp: $187-189{ }^{\circ} \mathrm{C}\left(\right.$ lit. $\left.^{10} 188{ }^{\circ} \mathrm{C}\right)$;

$\mathbf{R}_{\mathbf{f}}=0.70\left(\mathrm{CH}_{2} \mathrm{Cl}_{2}:\right.$ hexanes, $\left.7: 1 \mathrm{v} / \mathrm{v}\right)$ 
${ }^{1}$ H NMR $\left(500 \mathrm{MHz}, \mathrm{CDCl}_{3}\right): \delta 8.40-8.42(\mathrm{~m}, 2 \mathrm{H}), 8.25-8.27(\mathrm{~m}, 2 \mathrm{H}), 7.73-7.75(\mathrm{~m}, 4 \mathrm{H}), 4.13(\mathrm{~s}, 6 \mathrm{H})$

${ }^{13}$ C NMR (126 MHz, $\left.\mathrm{CDCl}_{3}\right): \delta 182.92,155.98,135.06,133.67,132.93,130.07,126.89,124.94,120.94$, 63.32

IR (ATR, cm $\left.{ }^{-1}\right)$ : 2935 (w), 2852 (w), 1666 (s), 1596 (m), 1400 (m), 1349 (s), 1272 (s), 1041 (m), 726 (s)

HRMS (m/z): $[\mathrm{M}+\mathrm{H}]^{+}$calcd. for $\mathrm{C}_{20} \mathrm{H}_{15} \mathrm{O}_{4}, 319.0970$; found, 319.0970 .

Control experiment: Synthesis of tetracene derivative S7:

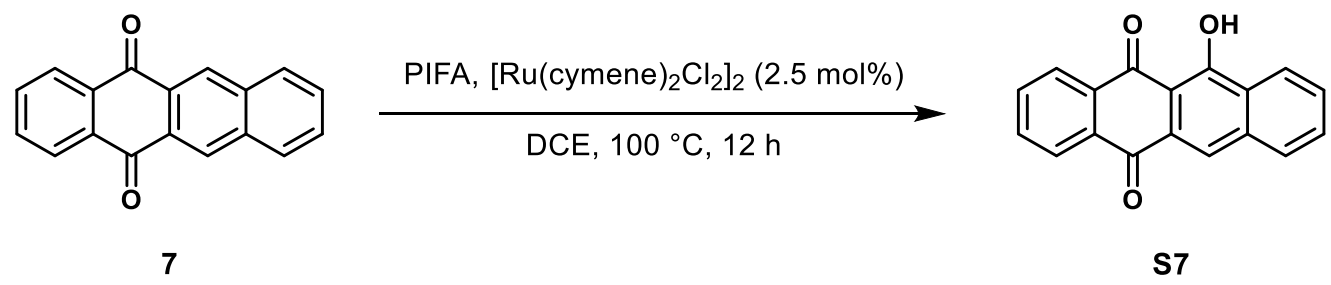

Tetracenequinone (7, $250.0 \mathrm{mg}, 967 \mu \mathrm{mol}, 1.0$ equiv.), [Ru(p-cymene) $\left.\mathrm{Cl}_{2}\right]_{2}(14.8 \mathrm{mg}, 24.2 \mu \mathrm{mol}, 2.5$ mol\%), and [bis(trifluoroacetoxy)iodo]benzene (PIFA, 1.04g, $2.42 \mu \mathrm{mol}, 2.5$ equiv.) were combined in a vial and purged with nitrogen. Dichloroethane (DCE, $390 \mu \mathrm{L}, 2.5 \mathrm{M}$ ) was added and the vial and was heated to $100{ }^{\circ} \mathrm{C}$ for $12 \mathrm{~h}$. After cooling the resulting purple solution to room temperature, water was added and the resulting mixture was extracted with $\mathrm{CH}_{2} \mathrm{Cl}_{2}(3 \times 30 \mathrm{~mL})$. The combined organic layers were dried with $\mathrm{MgSO}_{4}$ and the solvent was removed under reduced pressure. The crude orange solid was purified via flash chromatography $\left(\mathrm{SiO}_{2}, \mathrm{CH}_{2} \mathrm{Cl}_{2}\right.$ :hexanes $\left.=7: 3\right)$ to afford the title compound $\mathbf{S 7}$ as an orange solid (96.2 $\mathrm{mg}$, $351 \mu \mathrm{mol}, 36 \%)$.

mp: $312.6-313.6^{\circ} \mathrm{C}\left(\right.$ lit. $\left.^{11} 306^{\circ} \mathrm{C}\right)$

$\mathbf{R}_{\mathbf{f}}=0.33 ;\left(\mathrm{CH}_{2} \mathrm{Cl}_{2}:\right.$ hexanes, $\left.7: 1 \mathrm{v} / \mathrm{v}\right)$

${ }^{1}$ H NMR (500 MHz, $\mathrm{CDCl}_{3}$ ): $\delta 14.57$ (s, 1H), 8.54 (d, J = 8.0 Hz, 1H), 8.39 (ddd, J = 13.5, 7.4, $3.4 \mathrm{~Hz}$, $2 \mathrm{H}), 8.34(\mathrm{~s}, 1 \mathrm{H}), 8.01(\mathrm{~d}, \mathrm{~J}=8.0 \mathrm{~Hz}, 1 \mathrm{H}), 7.82-7.84(\mathrm{~m}, 2 \mathrm{H}) 7.67-7.69(\mathrm{~m}, 2 \mathrm{H})$

${ }^{13} \mathrm{C} \mathrm{NMR}\left(126 \mathrm{MHz}, \mathrm{CDCl}_{3}\right): \delta 187.80,182.52,163.73,136.34,134.64,134.43,134.15,131.22,130.36$, 128.93, 128.60, 127.84, 127.65, 127.03 (overlap of two peaks found by HSQC), 124.83, 121.79, 109.56; IR (ATR, cm-1): 2917 (m), 1671 (m), 1615 (w), 1593 (m), 1457 (m), 1389 (m), 1282 (s) 752 (m), 715 (s); HRMS (m/z): $[\mathrm{M}+\mathrm{H}]^{+}$calcd. for $\mathrm{C}_{18} \mathrm{H}_{11} \mathrm{O}_{3}, 275.0701$; found, 275.0708. These data are consistent with those reported in the literature. ${ }^{11,12}$ 
Synthesis of boronic ester $\mathbf{8}$ via dearomative hydroboration:

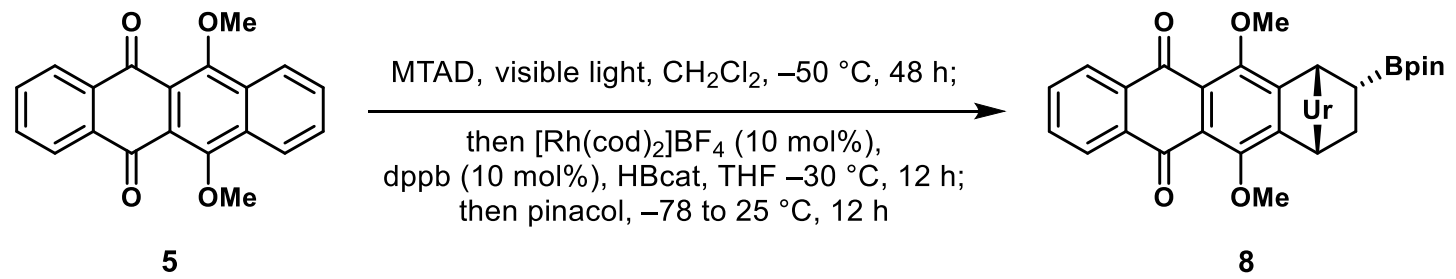

A $250 \mathrm{~mL}$ Schlenk flask containing tetracene derivative 5 (3.00 g, $9.42 \mathrm{mmol}, 1.0$ equiv.) and MTAD (1.28 $\mathrm{g}, 11.3 \mathrm{mmol}, 1.2$ equiv.) was evacuated and refilled with nitrogen five times. $\mathrm{CH}_{2} \mathrm{Cl}_{2}(100 \mathrm{~mL})$ was added and the flask was immediately cooled to $-50{ }^{\circ} \mathrm{C}$ and irradiated with visible light. After the pink and yellow solution had become yellow-orange (36-48 h, see Photo S1), the LED lights were turned off and the reaction was cooled to $-78{ }^{\circ} \mathrm{C}$. Then THF $(100 \mathrm{~mL})$ was slowly added followed by a solution containing $\left[\mathrm{Rh}(\mathrm{cod})_{2}\right] \mathrm{BF}_{4}(383.8 \mathrm{mg}, 0.94 \mathrm{mmol}, 10 \mathrm{~mol} \%)$ and dppb (389.1 mg, $\left.0.942 \mathrm{mmol}, 10 \mathrm{~mol} \%\right)$ in $\mathrm{CH}_{2} \mathrm{Cl}_{2}$ (4 $\mathrm{mL}$ ). HBcat (2.02 mL, $18.8 \mathrm{mmol}, 2.0$ equiv.) was added dropwise and the flask was placed in a $-30{ }^{\circ} \mathrm{C}$ cooling bath for $24 \mathrm{~h}$. The reaction was cooled to $-78{ }^{\circ} \mathrm{C}$, ethanol $(550 \mu \mathrm{L}, 9.42 \mathrm{mmol}, 1.0$ equiv) was added followed by a solution of pinacol $(1.11 \mathrm{~g}, 9.42 \mathrm{mmol}, 1.0$ equiv.) in THF (4.71 mL). The reaction was warmed to room temperature slowly over $12 \mathrm{~h}$. A solution of saturated sodium chloride (100 mL) was added and aqueous layer extracted with $\mathrm{CH}_{2} \mathrm{Cl}_{2}$ until no color remained in the aqueous layer. Combined organic phases were dried over $\mathrm{MgSO}_{4}$, concentrated under reduced pressure, and residue purified under an inert atmosphere by flash chromatography $\left(\mathrm{SiO}_{2}\right.$, hexanes: $\left.\mathrm{CH}_{2} \mathrm{Cl}_{2}: \mathrm{Et}_{2} \mathrm{O}=2: 1: 1\right)$ to afford the title compound as a yellow solid ( $2.9 \mathrm{~g}, 9.42 \mathrm{mmol}, 55 \%, 3: 1 \mathrm{dr})$. The two diastereomers were inseparable by chromatography and were used in the following reaction as a 3:1 mixture. The major diastereomer could be isolated by precipitation from diethyl ether.

mp: $126-128^{\circ} \mathrm{C}$ [decomposition]

$\mathbf{R}_{\mathbf{f}}=0.16$ (hexanes: $\mathrm{CH}_{2} \mathrm{Cl}_{2}: \mathrm{Et}_{2} \mathrm{O}, 2: 1: 1 \mathrm{v} / \mathrm{v} / \mathrm{v}$ )

${ }^{1} \mathbf{H}$ NMR (500 MHz, $\left.\mathrm{CDCl}_{3}\right): \delta 8.14-8.20(\mathrm{~m}, 2 \mathrm{H}), 7.73-7.76(\mathrm{~m}, 2 \mathrm{H}), 5.91(\mathrm{~d}, \mathrm{~J}=2.8 \mathrm{~Hz}, 1 \mathrm{H}), 5.81$ (dd, J = 3.5, 2.6 Hz, 1H), 4.04 (s, 3H), 4.02 (s, 3H) 2.89 (s, 3H), 2.51 (ddd, J = 13.5, 10.4, 3.5 Hz, 1H), 2.19 (ddd, J = 10.4, 5.0, $2.8 \mathrm{~Hz}, 1 \mathrm{H}), 1.79$ (ddd, J = 13.5, 5.0, $2.6 \mathrm{~Hz}, 1 \mathrm{H}), 1.01$ (s, 6H), 0.98 (s, 6H)

${ }^{13}$ C NMR (126 MHz, $\left.\mathrm{CDCl}_{3}\right): \delta 182.89,182.57,156.58,156.14,151.74,150.88,137.74,137.40,133.97$, $133.955,133.949,133.91,127.81,127.57,126.79,126.72,84.36,63.97,63.92,49.46,48.09,25.52,25.21$, $24.62,24.57,19.87$

IR (ATR, cm $\left.{ }^{-1}\right): 2978$ (w), 2944 (w), 1768 (m), 1707 (s), 1671 (s), 1593 (m), 1577 (m), 1312 (s)

HRMS (m/z): $[\mathrm{M}+\mathrm{H}]^{+}$calcd. for $\mathrm{C}_{29} \mathrm{H}_{31} \mathrm{~N}_{3} \mathrm{O}_{8} \mathrm{~B}, 560.2204$; found, 560.2216. 


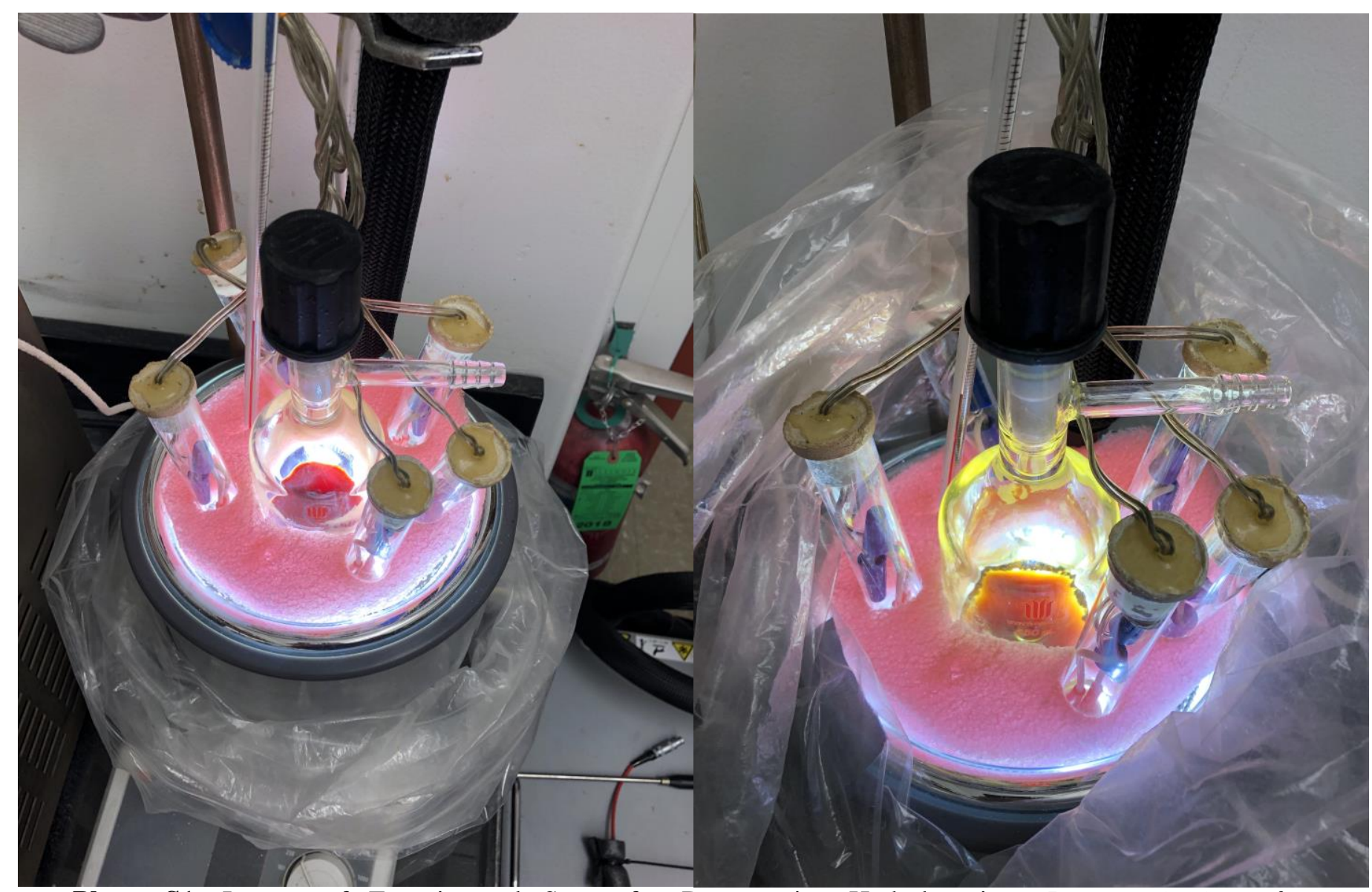

Photo S1. Images of Experimental Setup for Dearomative Hydroboration: Dearomatization of dimethoxytetracenequinone 5 with MTAD at $-50{ }^{\circ} \mathrm{C}$ after 5 minutes (left) and 48 hours (right).

Synthesis of ketone 9 via Zweifel Olefination:

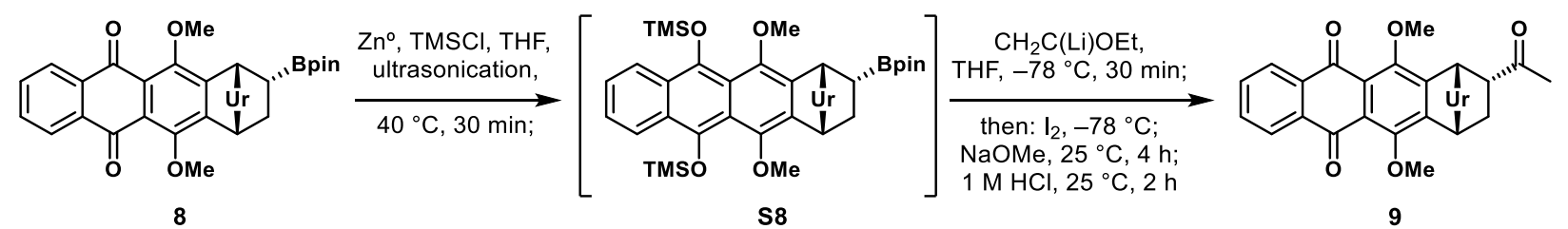

To a flask containing boronic ester $8(3.0 \mathrm{~g}, 5.36 \mathrm{mmol}, 1.0$ equiv.) was added solid zinc powder (701 $\mathrm{mg}$, $10.7 \mathrm{mmol}, 2.0$ equiv), THF (17.9 mL, $0.3 \mathrm{M})$, freshly distilled TMSCl (1.4 mL, $10.7 \mathrm{mmol}, 2.0$ equiv), and the resulting mixture was sonicated at $40{ }^{\circ} \mathrm{C}$ for $1.5 \mathrm{~h}$, resulting in a dark red solution. Separately, to a cold $\left(-78^{\circ} \mathrm{C}\right)$ solution of freshly distilled ethyl vinyl ether $(8.14 \mathrm{~mL}, 80.5 \mathrm{mmol}, 15$ equiv) in THF (107 $\mathrm{mL}, 0.05 \mathrm{M}$ relative to ester 8 ) was added dropwise $t \mathrm{BuLi}(31.5 \mathrm{~mL}, 1.7 \mathrm{M}$ in pentane, $53.6 \mathrm{mmol}, 10$ equiv.). After stirring at $-78{ }^{\circ} \mathrm{C}$ for $30 \mathrm{~min}$, the flask was placed in an ice bath for $20 \mathrm{~min}$, during which time the yellow color dissipated, and then cooled again to $-78{ }^{\circ} \mathrm{C}$. The solution of $\mathbf{S 8}$ was removed from the sonication bath, allowed to cool to room temperature, and was added dropwise to the solution of 
ethoxyvinyllithium at $-78{ }^{\circ} \mathrm{C}$, resulting in a red solution. After stirring at $-78{ }^{\circ} \mathrm{C}$ for $30 \mathrm{~min}$, the cryogenic bath was removed while stirring continued until the reaction reached an internal temperature of $-25{ }^{\circ} \mathrm{C}$ (approximately $12 \mathrm{~min}$ at this scale). Then, the flask was immediately cooled to $-78{ }^{\circ} \mathrm{C}$ and a solution of iodine (10.9 g, $42.9 \mathrm{mmol}, 8.0$ equiv.) in THF (10 mL) was added dropwise, resulting in a burgundy solution. The mixture was stirred at $-78{ }^{\circ} \mathrm{C}$ for $30 \mathrm{~min}$ before the cryogenic bath was removed for another $12 \mathrm{~min}$. The flask was once again cooled to $-78{ }^{\circ} \mathrm{C}$ before a solution of sodium methoxide $(17.1 \mathrm{~g}, 80.5$ mmol, 15 equiv.) in methanol ( $22 \mathrm{~mL})$ was added dropwise, resulting in a dark red solution. After keeping the reaction at $-78{ }^{\circ} \mathrm{C}$ for $30 \mathrm{~min}$, the cryogenic bath was removed and stirring continued for an additional 4 hours at room temperature. Then aqueous $\mathrm{HCl}$ was added $(150 \mathrm{~mL}, 1 \mathrm{M})$ and the yellow solution was allowed to stir until hydrolysis of the vinyl ether to the methyl ketone 9 was complete (approximately 2 hours, monitored by TLC). The layers were separated, and the aqueous layer was extracted repeatedly with $\mathrm{CH}_{2} \mathrm{Cl}_{2}$ until color in the aqueous phase no longer persisted. The organic layers were combined and the solvent was removed under reduced pressure resulting in a black-brown oil. This oil was dissolved in ethyl acetate $(100 \mathrm{~mL})$, washed with a saturated solution of $\mathrm{Na}_{2} \mathrm{~S}_{2} \mathrm{O}_{3}(3 \times 150 \mathrm{~mL})$, saturated sodium chloride solution (150 mL), dried over $\mathrm{MgSO}_{4}$, and concentrated to afford a brown-yellow oil. Purification by flash chromatography $\left(\mathrm{SiO}_{2}\right.$, hexanes: $\left.\mathrm{CH}_{2} \mathrm{Cl}_{2}: \mathrm{EtOAc}=2: 1: 1\right)$ afforded the title compound $\mathbf{9}$ as a yellow solid (1.22 g, $3.58 \mathrm{mmol}, 72 \%)$.

mp: $156-158{ }^{\circ} \mathrm{C}$ [decomposition]

$\mathbf{R}_{\mathbf{f}}=0.12$ (hexanes: $\mathrm{CH}_{2} \mathrm{Cl}_{2}:$ EtOAc, $2: 1: 1 \mathrm{v} / \mathrm{v} / \mathrm{v}$ )

${ }^{1}$ H NMR (500 MHz, $\left.\mathrm{CDCl}_{3}\right): \delta 8.14-8.16(\mathrm{~m}, 2 \mathrm{H}), 7.74-7.76(\mathrm{~m}, 2 \mathrm{H}), 6.15(\mathrm{~d}, \mathrm{~J}=3.0 \mathrm{~Hz}, 1 \mathrm{H}), 5.58$ $(\mathrm{dd}, \mathrm{J}=3.5,2.6 \mathrm{~Hz}, 1 \mathrm{H}), 4.06(\mathrm{~s}, 3 \mathrm{H}), 4.04(\mathrm{~s}, 3 \mathrm{H}), 3.56(\mathrm{ddd}, \mathrm{J}=9.7,4.5,3.0 \mathrm{~Hz}, 1 \mathrm{H}), 2.92(\mathrm{~s}, 3 \mathrm{H}), 2.44$ (ddd, J = 13.7, 9.7, 3.5 Hz, 1H), $2.30(\mathrm{~s}, 3 \mathrm{H}), 2.25$ (ddd, J = 13.7, 4.5, $2.6 \mathrm{~Hz}, 1 \mathrm{H})$

${ }^{13}$ C NMR (126 MHz, $\left.\mathrm{CDCl}_{3}\right): \delta 203.15,182.61,182.58,156.48,156.35,151.62,150.97,137.16,134.07$, 134.05, 133.89, 133.86, 133.81, 128.72, 128.07, 126.80, 126.78, 64.36, 64.15, 49.17, 47.99, 47.68, 28.60, $25.77,24.96$

IR (ATR, cm $\left.{ }^{-1}\right): 2926$ (w), 1714 (s), 1673 (m), 1592 (w), 1458 (m), 1312 (m), 1258 (m), 983 (w)

HRMS (m/z): $[\mathrm{M}+\mathrm{H}]^{+}$calcd. for $\mathrm{C}_{25} \mathrm{H}_{22} \mathrm{~N}_{3} \mathrm{O}_{7}, 476.1458$; found, 476.1481 . 
Synthesis of enone 10:

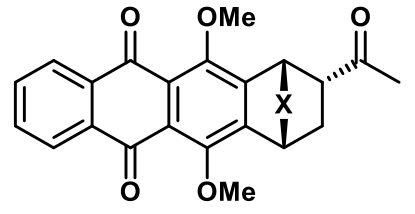

9

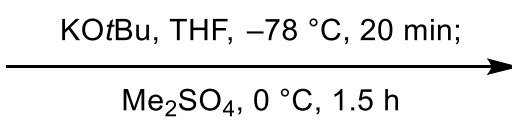

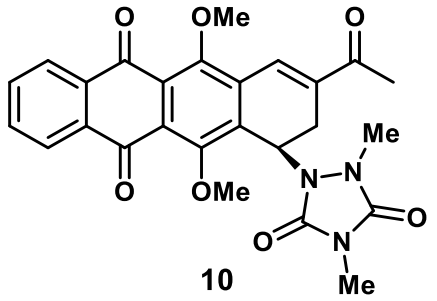

To a cold $\left(-78^{\circ} \mathrm{C}\right)$ solution of $\mathbf{9}(500.0 \mathrm{mg}, 1.05 \mathrm{mmol}, 1.0$ equiv. $)$ in THF $(10.5 \mathrm{~mL})$ was added a solution of $t \mathrm{BuOK}$ (129.8 mg, $1.16 \mathrm{mmol}, 1.1$ equiv.) in THF (1.16 mL) dropwise. This resulted in the yellow solution turning dark purple. After 20 minutes, dimethyl sulfate ( $502 \mu \mathrm{L}, 5.26 \mathrm{mmol}, 5.0$ equiv.) was added and the reaction was warmed to $0{ }^{\circ} \mathrm{C}$ for and stirred at this temperature for 1.5 hours. The crude reaction mixture was concentrated under reduced pressure at $0{ }^{\circ} \mathrm{C}$ and used without purification in the next step. To obtain analytically pure sample, residue was dry loaded on celite and immediately purified via flash chromatography $\left(\mathrm{SiO}_{2}\right.$, hexanes: $\mathrm{CH}_{2} \mathrm{Cl}_{2}:$ EtOAc $\left.=1: 3: 3\right)$ to deliver the title compound $\mathbf{1 0}$ as a yellow solid (407.3 mg, $0.831 \mathrm{mmol}, 79 \%$ ).

mp: $159-161{ }^{\circ} \mathrm{C}$ [decomposition]

$\mathbf{R}_{\mathbf{f}}=0.25$ (hexanes: $\mathrm{CH}_{2} \mathrm{Cl}_{2}:$ EtOAc, $1: 3: 3 \mathrm{v} / \mathrm{v} / \mathrm{v}$ ):

${ }^{1}$ H NMR (500 MHz, $\left.\mathrm{CDCl}_{3}\right): \delta 8.19-8.21(\mathrm{~m}, 2 \mathrm{H}), 7.92(\mathrm{~d}, \mathrm{~J}=3.0 \mathrm{~Hz}, 1 \mathrm{H}), 7.77-7.79(\mathrm{~m}, 2 \mathrm{H}), 5.87$ (dd, J = 9.5, 1.2 Hz, 1H), 4.01 (s, 3H), 3.98 (s, 3H), 3.23 (dd, J = 19.3, $1.2 \mathrm{~Hz}, 1 \mathrm{H}), 3.05$ (s, 3H), 2.75, (s, 3H), 2.61 (ddd, J = 19.3, 9.5, 3.0 Hz, 1H), 2.53 (s, 3H)

${ }^{13}$ C NMR (126 MHz, $\left.\mathrm{CDCl}_{3}\right): \delta 197.40,182.62,182.05,156.69,156.03,155.33,153.93,138.70,135.82$, 134.21, 134.12, 134.05, 133.90, 133.37, 128.37, 127.85, 127.45, 126.96, 126.82, 63.66, 63.03, 48.06, 35.89, $26.12,25.98,25.85$

IR (ATR, cm $\left.{ }^{-1}\right): 2940$ (w), 1772 (m), 1708 (s), 1667 (s), 1476 (m), 1457 (m), 1324 (s) 1239 (s), 1036 (m); HRMS (m/z): $[\mathrm{M}+\mathrm{H}]^{+}$calcd. for $\mathrm{C}_{26} \mathrm{H}_{24} \mathrm{~N}_{3} \mathrm{O}_{7}, 490.1614$; found, 490.1613 . 
Table S2: The influence of $N$-substitution on Mukaiyama hydration:

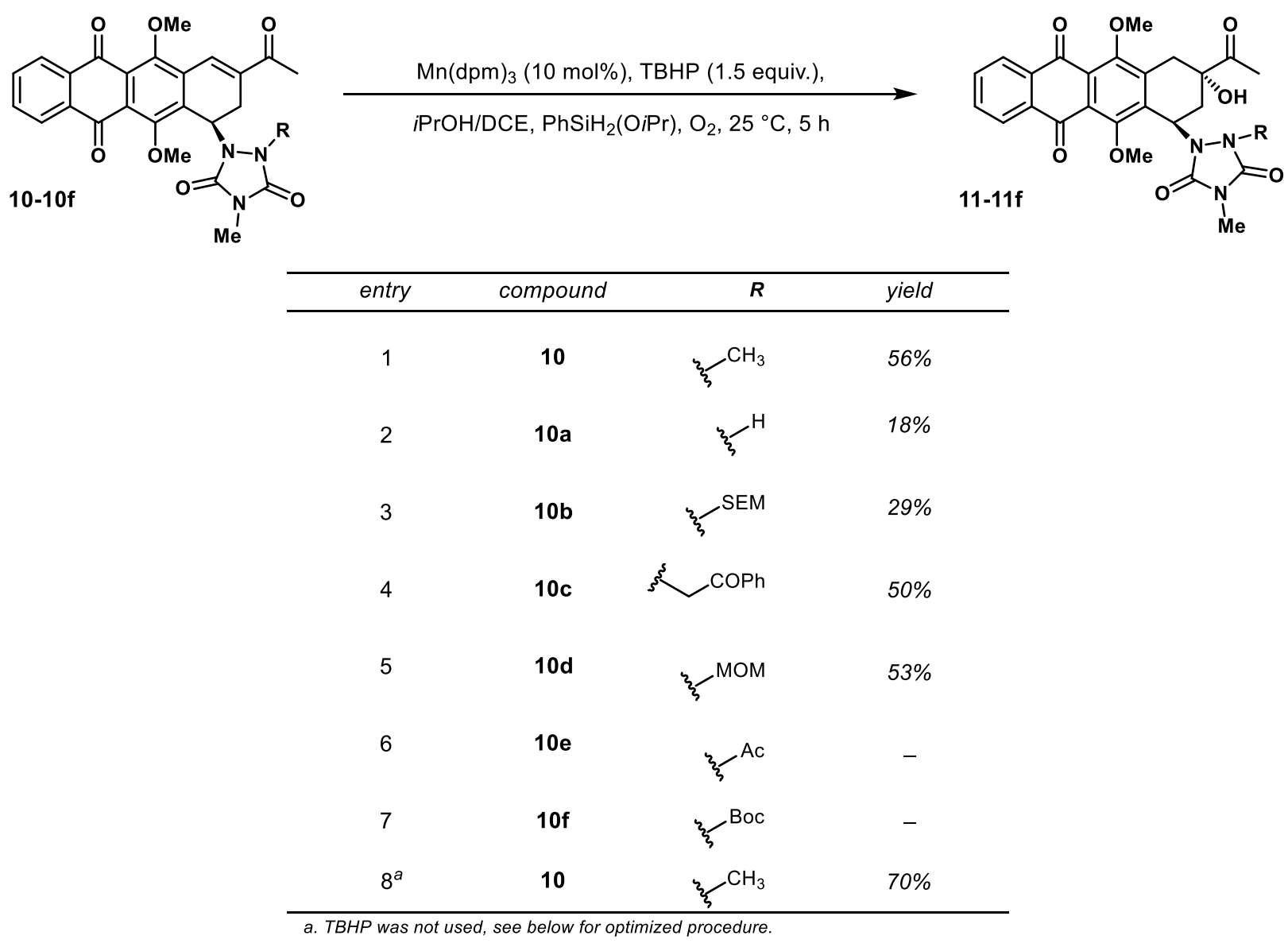

Synthesis of $\alpha$-ketol 11 via Mukaiyama hydration:<smiles>COc1c2c(c(OC)c3c1C(=O)c1ccccc1C3=O)C(n1c(=O)n(C)c(=O)n1C)CC(C(C)=O)=C2</smiles>
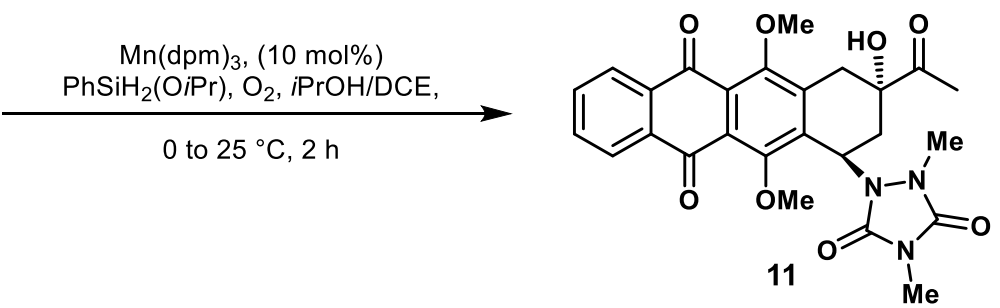

To a solution of enone $10\left(500.0 \mathrm{mg}, 1.02 \mathrm{mmol}, 1.0\right.$ equiv.) in $i \mathrm{PrOH}(5 \mathrm{~mL})$ and $\mathrm{DCE}(5 \mathrm{~mL})$ at $0{ }^{\circ} \mathrm{C}$ was added $\mathrm{Mn}(\mathrm{dpm})_{3}(61.8 \mathrm{mg}, 0.102 \mathrm{mmol}, 10 \mathrm{~mol} \%)$ and oxygen was bubbled through the dark reaction mixture for $5 \mathrm{~min}$. Then, isopropoxy(phenyl)silane $(640 \mu \mathrm{L}, 3.064 \mathrm{mmol}, 3.0$ equiv.) was added in portions over the course of $1 \mathrm{~h}$ at ambient temperature while oxygen continued to bubble through the reaction mixture. After the addition, the reaction was stirred for an additional hour. Celite (1g) was added to the mixture, solvent was removed in vacuo, and the residue was purified via flash chromatography $\left(\mathrm{SiO}_{2}\right.$, hexanes: $\mathrm{CH}_{2} \mathrm{Cl}_{2}$ :EtOAc = 1:3:3) to provide the title compound $\mathbf{1 1}$ as a yellow solid $(365.5 \mathrm{mg}, 0.719 \mathrm{mmol}$, $70 \%)$. 
mp: $129-130{ }^{\circ} \mathrm{C}$ [decomposition]

$\mathbf{R}_{\mathbf{f}}=0.11$ (hexanes: $\mathrm{CH}_{2} \mathrm{Cl}_{2}:$ EtOAc, $1: 3: 3 \mathrm{v} / \mathrm{v} / \mathrm{v}$ )

${ }^{1} \mathbf{H}$ NMR $\left(500 \mathrm{MHz}, \mathrm{CDCl}_{3}\right): \delta 8.13-8.17(\mathrm{~m}, 2 \mathrm{H}), 7.71-7.74(\mathrm{~m}, 2 \mathrm{H}), 5.76(\mathrm{t}, \mathrm{J}=9.0 \mathrm{~Hz}, 1 \mathrm{H}), 3.99(\mathrm{~s}$, $1 \mathrm{H}), 3.87(\mathrm{~s}, 6 \mathrm{H}), 3.06-3.20(\mathrm{~m}, 5 \mathrm{H}), 2.90(\mathrm{~s}, 3 \mathrm{H}), 2.42,(\mathrm{~s}, 3 \mathrm{H}), 2.24-2.32(\mathrm{~m}, 2 \mathrm{H})$

${ }^{13}$ C NMR (126 MHz, $\left.\mathrm{CDCl}_{3}\right): \delta$ 209.83, 182.70, 182.32, 156.39, 155.54, 155.00, 154.70, 139.33, 135.71, 134.02, 133.97, 133.85 (overlap of two peaks found by HSQC), 126.80, 126.71, 126.48, 125.00, 77.36, $62.46,62.00,51.22,34.59,34.28,32.92,25.76,24.28$

IR (ATR, cm ${ }^{-1}$ ): 3429 (br), 2927 (w), 2854 (w), 1764 (m), 1700 (s), 1672 (s), 1482 (m), 1259 (s), 1101 (m), $1036(\mathrm{~m})$

HRMS (m/z): $[\mathrm{M}+\mathrm{H}]^{+}$calcd. for $\mathrm{C}_{26} \mathrm{H}_{26} \mathrm{~N}_{3} \mathrm{O}_{8}, 508.1720$; found, 508.1712.

\section{Preparation of $\alpha$-ketol 12:}
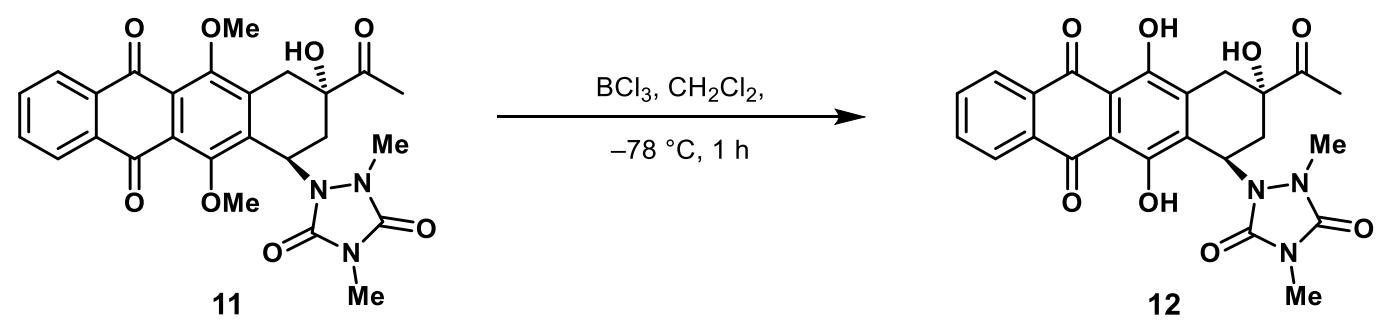

To a cold $\left(-78{ }^{\circ} \mathrm{C}\right)$ solution of $\alpha$-ketol $11\left(545.7 \mathrm{mg}, 1.07 \mathrm{mmol}, 1.0\right.$ equiv.) in $\mathrm{CH}_{2} \mathrm{Cl}_{2}(10.7 \mathrm{~mL}, 0.1 \mathrm{M})$ was dropwise added $\mathrm{BCl}_{3}\left(10.7 \mathrm{~mL}, 1 \mathrm{M}\right.$ in $\mathrm{CH}_{2} \mathrm{Cl}_{2}, 10.7 \mathrm{mmol}, 10$ equiv.). Stirring was continued for additional hour at which point $10 \mathrm{~mL}$ of methanol was slowly added and the reaction mixture was allowed to warm to room temperature. The solution was concentrated under reduced pressure to give a red gummy residue. Purification via flash chromatography $\left(\mathrm{SiO}_{2}, \mathrm{CH}_{2} \mathrm{Cl}_{2}: \mathrm{EtOAc}=8: 2,1 \% \mathrm{AcOH}\right)$ provided the title compound 12 as a red solid (505.9 mg, $1.05 \mathrm{mmol}, 98 \%)$.

mp: $248.2-248.9{ }^{\circ} \mathrm{C}$

$\mathbf{R}_{\mathbf{f}}=0.23\left(\mathrm{CH}_{2} \mathrm{Cl}_{2}:\right.$ EtOAc, $\left.8: 2 \mathrm{v} / \mathrm{v}, 1 \% \mathrm{AcOH}\right)$

${ }^{1}$ H NMR (500 MHz, DMSO- $\left.d_{6}\right): \delta 13.49$ (s, 1H), $13.24(\mathrm{~s}, 1 \mathrm{H}), 8.23$ - $8.26(\mathrm{~m}, 2 \mathrm{H}), 7.96-7.98$ (m, 2H), $5.94(\mathrm{~s}, 1 \mathrm{H}), 5.61(\mathrm{t}, \mathrm{J}=9.3 \mathrm{~Hz}, 1 \mathrm{H}), 2.97-3.11(\mathrm{~m}, 5 \mathrm{H}), 2.85(\mathrm{~s}, 3 \mathrm{H}), 2.33-2.38(\mathrm{~m}, 4 \mathrm{H}), 2.11(\mathrm{dd}, \mathrm{J}=$ $13.5,9.3 \mathrm{~Hz}, 1 \mathrm{H})$

${ }^{13}$ C NMR (126 MHz, DMSO- $\left.d_{6}\right): \delta$ 211.52, 186.69, 186.64, 155.87, 155.19, 154.96, 154.44, 138.50, 135.13, 153.08, 132.92, 132.80, 132.03, 126.67, 126.63, 111.16, 109.98, 76.21, 50.83, 34.51, 34.49, 31.38, 25.30, 24.48

IR $\left(\right.$ ATR, $\left.\mathrm{cm}^{-1}\right)$ : 3259 (br), 2926 (w), 1766 (m), 1704 (s), 1624 (m), 1586 (m), 1403 (s), 1246 (s), 1115 (m), $734(\mathrm{~m})$

HRMS (m/z): [M+Na $]^{+}$calcd. for $\mathrm{C}_{24} \mathrm{H}_{21} \mathrm{~N}_{3} \mathrm{O}_{8} \mathrm{Na}, 502.1226$; found, 502.1233. 
Table S3: Optimization of the final transformation of hydroquinone 12.

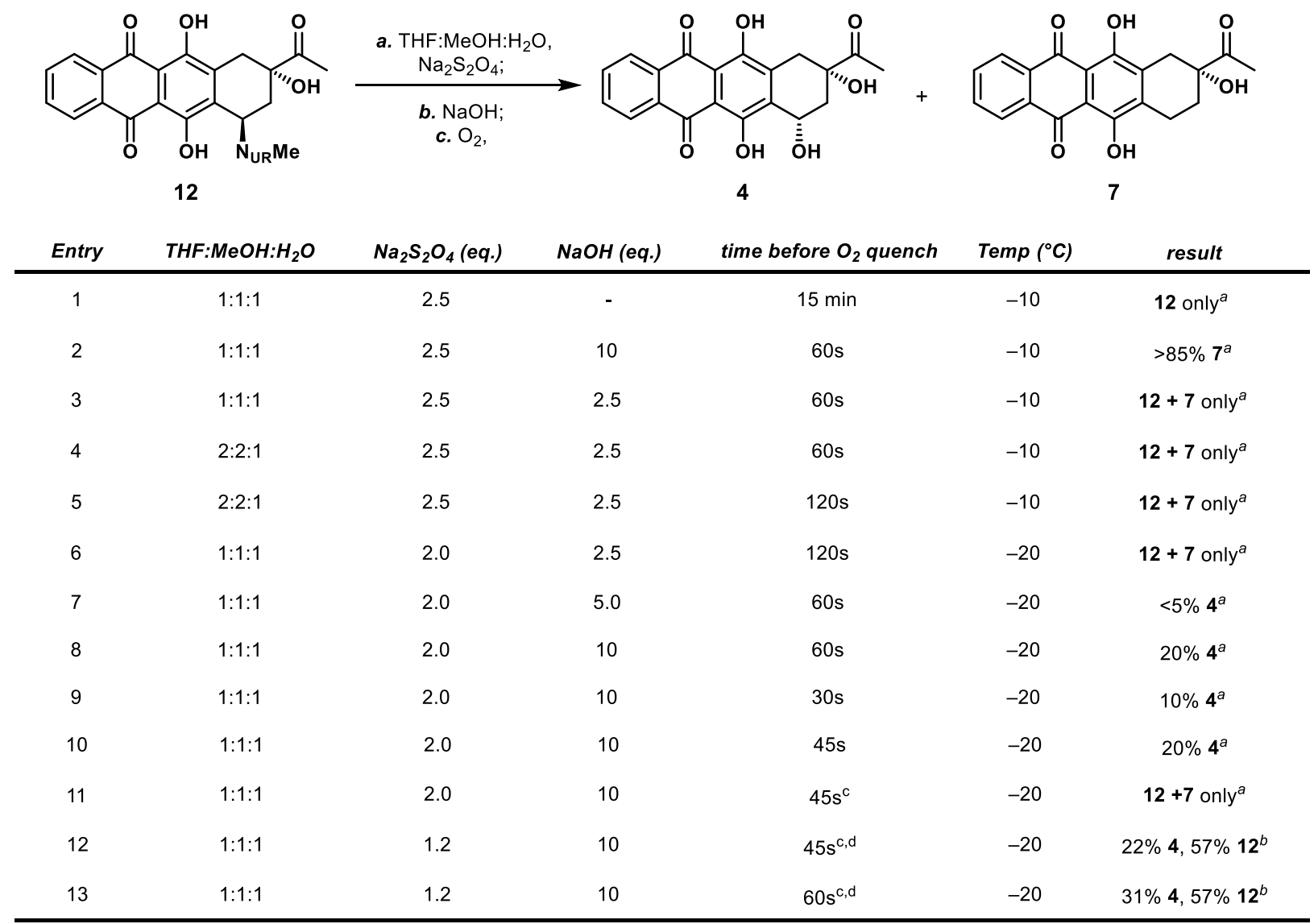

a.yield determined by NMR using 1,1,2,2-tetrachloroethane b.isolated yield c. $0.10 \mathrm{mmol}$ scale instead of $0.02 \mathrm{mmol}$ d.gas dispersion tube used to quench with $\mathrm{O}_{2}$ instead of a needle.

Preparation of idarubicinone (4) and 7-deoxyidarubicinone (13):<smiles>[Z]OC(=O)O[Na]</smiles>

A flask charged with $12\left(50.0 \mathrm{mg}, 104 \mu \mathrm{mol}, 1.0\right.$ equiv.) and sodium dithionite $\left(\mathrm{Na}_{2} \mathrm{~S}_{2} \mathrm{O}_{4}\right)(32.2 \mathrm{mg}, 85$ $\mathrm{wt} \%, 156 \mu \mathrm{mol}, 1.5$ equiv.) was purged with nitrogen for $10 \mathrm{~min}$. Degassed THF (2.09 mL, $0.05 \mathrm{M}), \mathrm{MeOH}$ (2.09 mL, $0.05 \mathrm{M})$, and $\mathrm{H}_{2} \mathrm{O}(2.09 \mathrm{~mL}, 0.05 \mathrm{M})$ were sequentially added, and the mixture was stirred at room temperature for $20 \mathrm{~min}$ at which time the light-red solution had darkened significantly. The flask was cooled to $-20^{\circ} \mathrm{C}$ and aqueous solution of $\mathrm{NaOH}(41.7 \mathrm{mg}, 1.0 \mathrm{M}, 10$ equiv.) was added, resulting in a deep 
blue solution. After $60 \mathrm{~s}$, the septum was removed, a gas dispersion tube connected to a balloon of $\mathrm{O}_{2}$ was submerged into the reaction mixture at $-20{ }^{\circ} \mathrm{C}$, causing the reaction mixture rapidly turned from deep blue to vibrant purple (see Photo S2 for details). The reaction was then diluted with $1 \mathrm{M}$ aqueous $\mathrm{HCl}$, extracted with EtOAc, and concentrated under reduced pressure. Purification via flash chromatography $\left(\mathrm{SiO}_{2}\right.$, hexanes:EtOAc $=8: 2,1 \% \mathrm{AcOH})$ provided idarubicinone (4) as a red solid (12.7 mg, $33 \mu \mathrm{mol}, 31 \%)$ and 7-deoxyidarubicinone $(\mathbf{1 3}, 21.4 \mathrm{mg}, 59.6 \mu \mathrm{mol}, 57 \%)$ also as a red solid.

Idarubicinone (4):

mp: $176.5-177.8\left(\right.$ lit. $\left.^{13} 176-178^{\circ} \mathrm{C}\right)$

$\mathbf{R}_{\mathbf{f}}=0.42$ (hexanes:EtOAc $\left.=8: 2 \mathrm{v} / \mathrm{v}, 1 \% \mathrm{AcOH}\right)$

${ }^{1}$ H NMR (500 MHz, $\mathrm{CDCl}_{3}$ ): 13.60 (s, 1H), 13.33 (s, 1H), $8.34-8.37$ (m, 2H), $7.83-7.86$ (m, 2H), 5.31 - $5.35(\mathrm{~m}, 1 \mathrm{H}), 4.53(\mathrm{~s}, 1 \mathrm{H}), 3.78(\mathrm{~d}, \mathrm{~J}=5.3 \mathrm{~Hz}, 1 \mathrm{H}), 3.20(\mathrm{dd}, \mathrm{J}=18.6,2.1 \mathrm{~Hz}, 1 \mathrm{H}), 2.97$ (d, J = 18.6 Hz, 1H), 2.43 (s, 3H), $2.36(\mathrm{dt}, \mathrm{J}=14.4,2.1,2.1 \mathrm{~Hz}, 1 \mathrm{H}) 2.19(\mathrm{dd}, \mathrm{J}=14.4,4.9 \mathrm{~Hz}, 1 \mathrm{H})$

${ }^{13}$ C NMR (126 MHz, $\left.\mathrm{CDCl}_{3}\right): \delta 211.67,187.06,186.94,156.64,156.35,135.88,134.98,134.75,134.74$, $133.62,133.59,127.28,127.22,111.54,111.08,76.96,61.93,35.59,33.44,24.62$

IR (ATR, cm ${ }^{-1}$ ): 2917 (s), 2849 (m), 1715 (m), 1626 (m),1587 (s), 1411 (m), 1373 (m), 1342 (w), 1262 (m), $1236(\mathrm{~s}), 1035(\mathrm{w})$

HRMS (m/z): [M-H $]^{+}$calcd. for $\mathrm{C}_{20} \mathrm{H}_{15} \mathrm{O}_{7}, 367.0816$; found, 367.0818

7-deoxyidarubicinone (13):

mp: $210.9-211.6^{\circ} \mathrm{C}\left(\right.$ lit. $\left.^{14} 210-211^{\circ} \mathrm{C}\right)$

$\mathbf{R}_{\mathbf{f}}=0.64$ (hexanes:EtOAc $=8: 2 \mathrm{v} / \mathrm{v}, 1 \% \mathrm{AcOH}$ )

${ }^{1}$ H NMR (500 MHz, DMSO- $\left.d_{6}\right): \delta 13.24-13.27(\mathrm{~m}, 2 \mathrm{H}), 8.17$ - 8.19 (m, 2H), $7.92-7.94$ (m, 2H), 5.67 (s, 1H), $2.70-2.88(\mathrm{~m}, 4 \mathrm{H}), 2.30(\mathrm{~s}, 3 \mathrm{H}), 1.90-1.97(\mathrm{~m}, 1 \mathrm{H}), 1.70-1.77(\mathrm{~m}, 2 \mathrm{H})$

${ }^{13}$ C NMR (126 MHz, DMSO-d $\left.d_{6}\right): \delta 212.87,186.01,185.95,155.89,155.32,137.08,136.07,134.81$ (overlap of two peaks found by HSQC), 132.79, 132.78, 126.46 (overlap of two peaks found by HSQC), 109.18, 109.07, 74.82, 31.63, 28.01, 24.38, 19.93

IR (ATR, cm ${ }^{-1}$ ): 3490 (br), 1702 (m), 1620 (m), 1586 (s), 1408 (s), 1376 (m), 1351 (m), 1315 (w), 1270 (s), $1205(\mathrm{w})$

HRMS (m/z): $[\mathrm{M}+\mathrm{H}]^{+}$calcd. for $\mathrm{C}_{20} \mathrm{H}_{17} \mathrm{O}_{6}, 353.1025$; found, 353.1022. These data are consistent with those reported in the literature. ${ }^{13,14}$ 

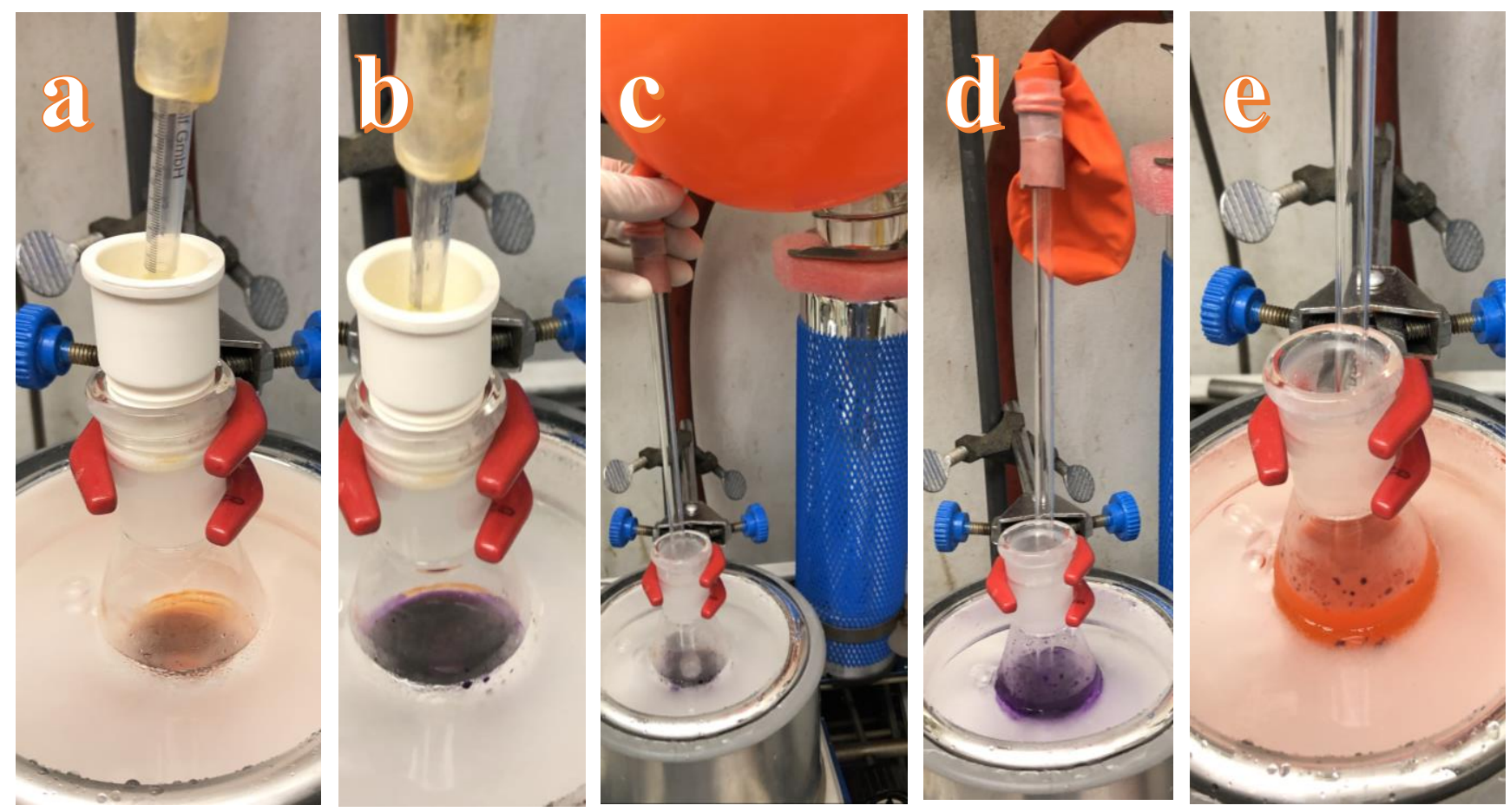

Photo S2. Images of experimental setup for the final transformation of hydroquinone 12: The reaction at different time points from left to right:a. before the addition of $\mathrm{NaOH} ; \boldsymbol{b} .10 \mathrm{~s}$ after the addition of $\mathrm{NaOH}$; c. $60 \mathrm{~s}$ after the addition of $\mathrm{NaOH}$; d. after the addition of $\mathrm{O}_{2}$; $\boldsymbol{e}$. after the addition of $1 \mathrm{M} \mathrm{HCl}$.

\section{References:}

1. Schenk, T. G. et al. Bimetallic Reactivity. Synthesis of Bimetallic Complexes Containing a Bis(phosphino)pyrazole Ligand. Inorg. Chem. 1985, 24, 2334.

2. Armarego, W.L.F.; Chai C.L.L, Purification of Laboratory Chemicals, $6^{\text {th }}$ edition, page 174. (Butterworth-Heinemann, Burlington MA, 2009).

3. Breton, G. W.; Turlington, M. Alternative synthetic routes to N-methyl-1,2,4-triazoline-3,5-dione (MeTAD) and other triazolinedione derivatives. Tet. Lett. 2014, 55, 4661.

4. Cookson, R. C.; Gupte, S. S.; Stevens, I. D. R.; Watts, C. T. 4-Phenyl-1,2,4-Triazoline-3,5-dione [3H1,2,4-Triazole-3,5(4H)-dione, 4-phenyl-]. Org. Synth. 1971, 51, 121.

5. Kanth, J. V. B.; Periasamy, M.; Brown, H. C. New Economical, Convenient Procedures for the Synthesis of Catecholborane. Org. Process Res. Dev. 2000, 4, 550.

6. Obradors, C.; Martinez, R. M.; Shenvi, R. A. Ph(i-PrO)SiH 2 : An Exceptional Reductant for MetalCatalyzed Hydrogen Atom Transfers. J. Am. Chem. Soc. 2016, 138, 4962. 
7. Dolomanov, O. V.; Bourhis, L. J.; Gildea, R. J.; Howard, J. A. K.; Puschmann, H. OLEX2: a complete structure solution, refinement and analysis program. J. Appl. Cryst, 2009, 42, 339.

8. Sheldrick, G. M. SHELXT-Integrated space-group and crystal-structure determination. Acta Cryst. 2015, $A 71,3$.

9. Nishina, Y.; Kida, T.; Ureshino, T. Facile Sc(OTf) ${ }_{3}$-Catalyzed Generation and Successive Aromatization of Isobenzofuran from o-Dicarbonylbenzenes. Org. Lett. 2011, 13, 3960.

10. Kotha, S.; Shah, V. R.; Mandal, K. Formation of Arenes via Diallylarenes: Strategic Utilization of Suzuki-Miyaura Cross-Coupling, Claisen Rearrangement and Ring-Closing Metathesis. Adv. Synth. Catal. 2007, 349, 1159.

11. Makhlouf, M. A.; Rickborn, B. 1-Methoxyisobenzofuran: Formation from 1,3-Dihydro-1,1dimethoxyisobenzofuran. J. Org. Chem. 1981, 46, 2734 ().

12. Park, I. S.; Heo, E.; Nam, Y.; Lee, C. W.; Kim, J. Colorimetric detection of aliphatic primary amines and a molecular logic gate based on a photochromic phenoxyquinone derivative. J. Photochem. Photobiol. A: Chem. 2012, 238, 1.

13. Allen, J. G.; Hentemann, M. F; Danishefsky, S. J. A Powerful $o$-Quinone Dimethide Strategy for Intermolecular Diels-Alder Cycloadditions. J. Am. Chem. Soc. 2000, 122, 571.

14. Broadhurst, M. J.; Hassall, C. H.; Thomas, G. J., Anthracyclines. Part 2. Investigations relating to the Synthesis of 4-Demethoxyanthracyclinones. J. Chem. Soc. Perkin Trans. 1982, 1, 2239. 


\section{IV. ${ }^{1} \mathrm{H}$ - and ${ }^{13} \mathrm{C}-\mathrm{NMR}$ Spectra of Compounds}

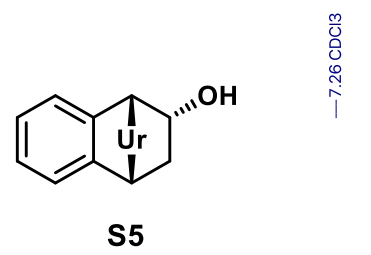

$\left({ }^{1} \mathrm{H} \mathrm{NMR}, \mathrm{CDCl}_{3}, 500 \mathrm{MHz}\right)$
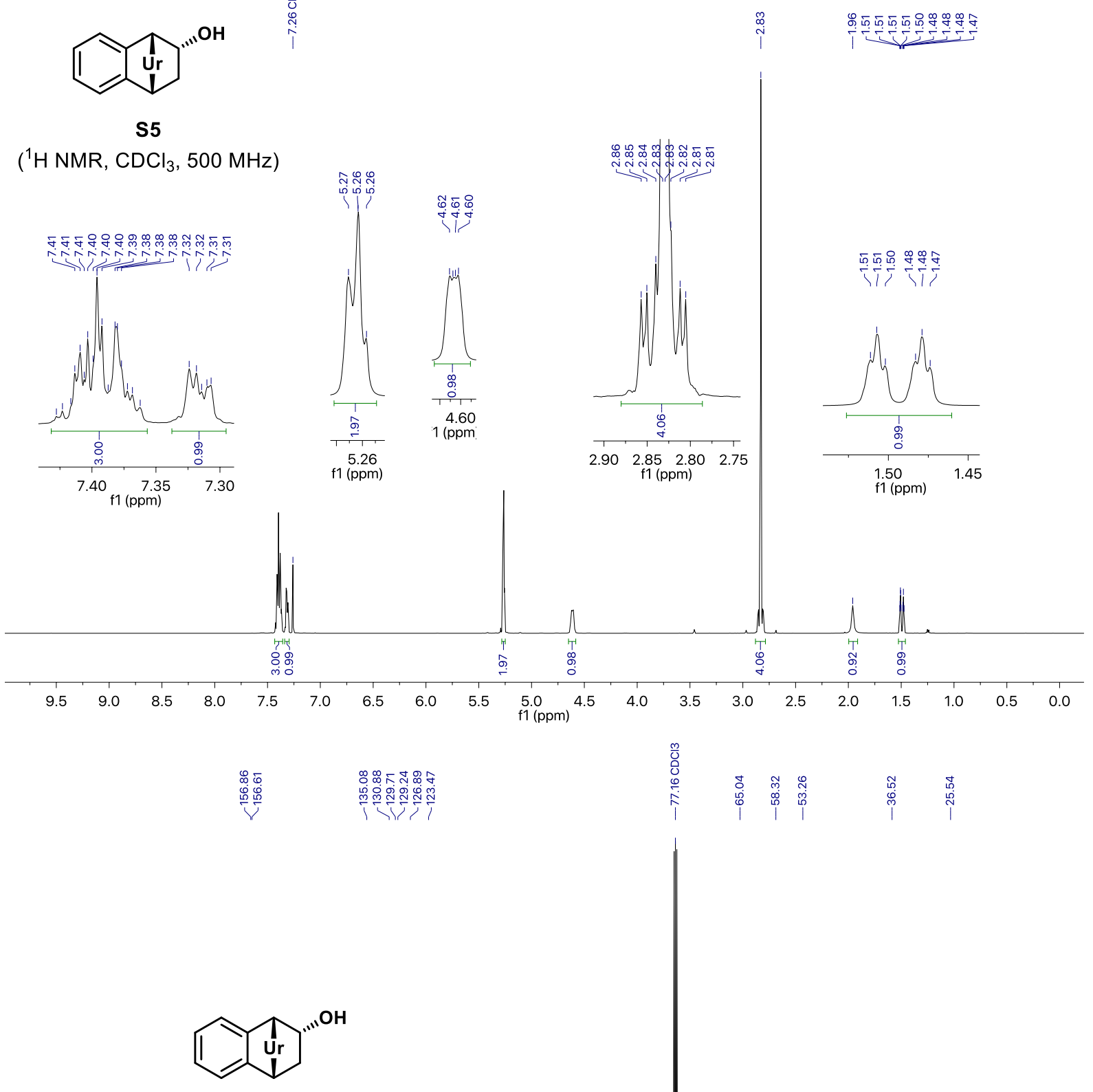

S5

$\left({ }^{13} \mathrm{C} \mathrm{NMR}, \mathrm{CDCl}_{3}, 126 \mathrm{MHz}\right)$

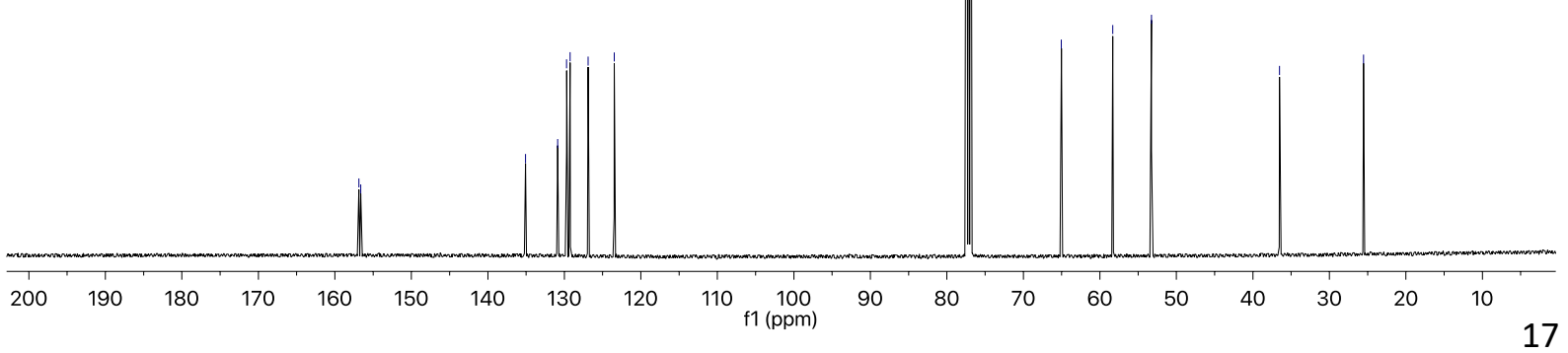



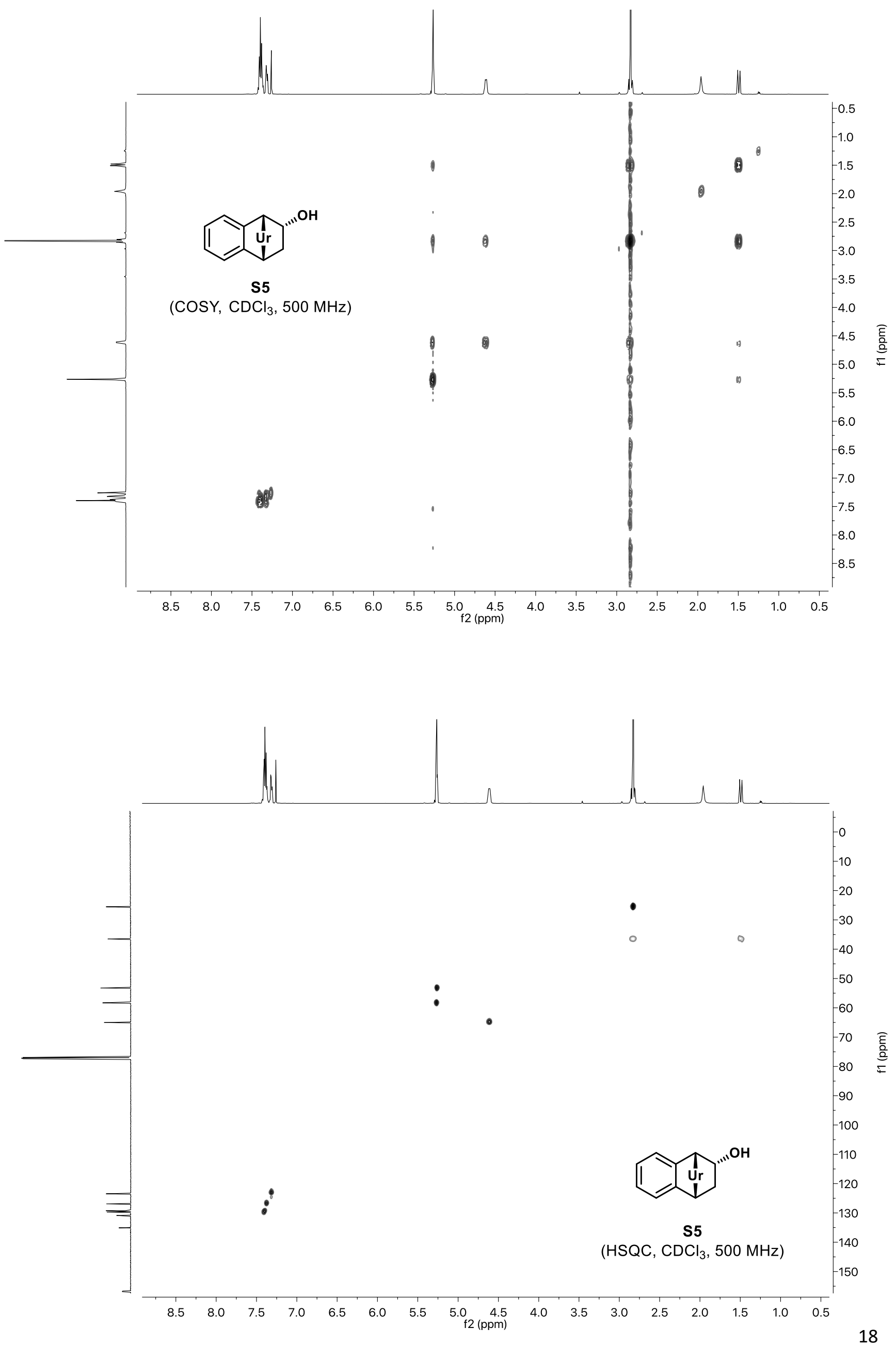

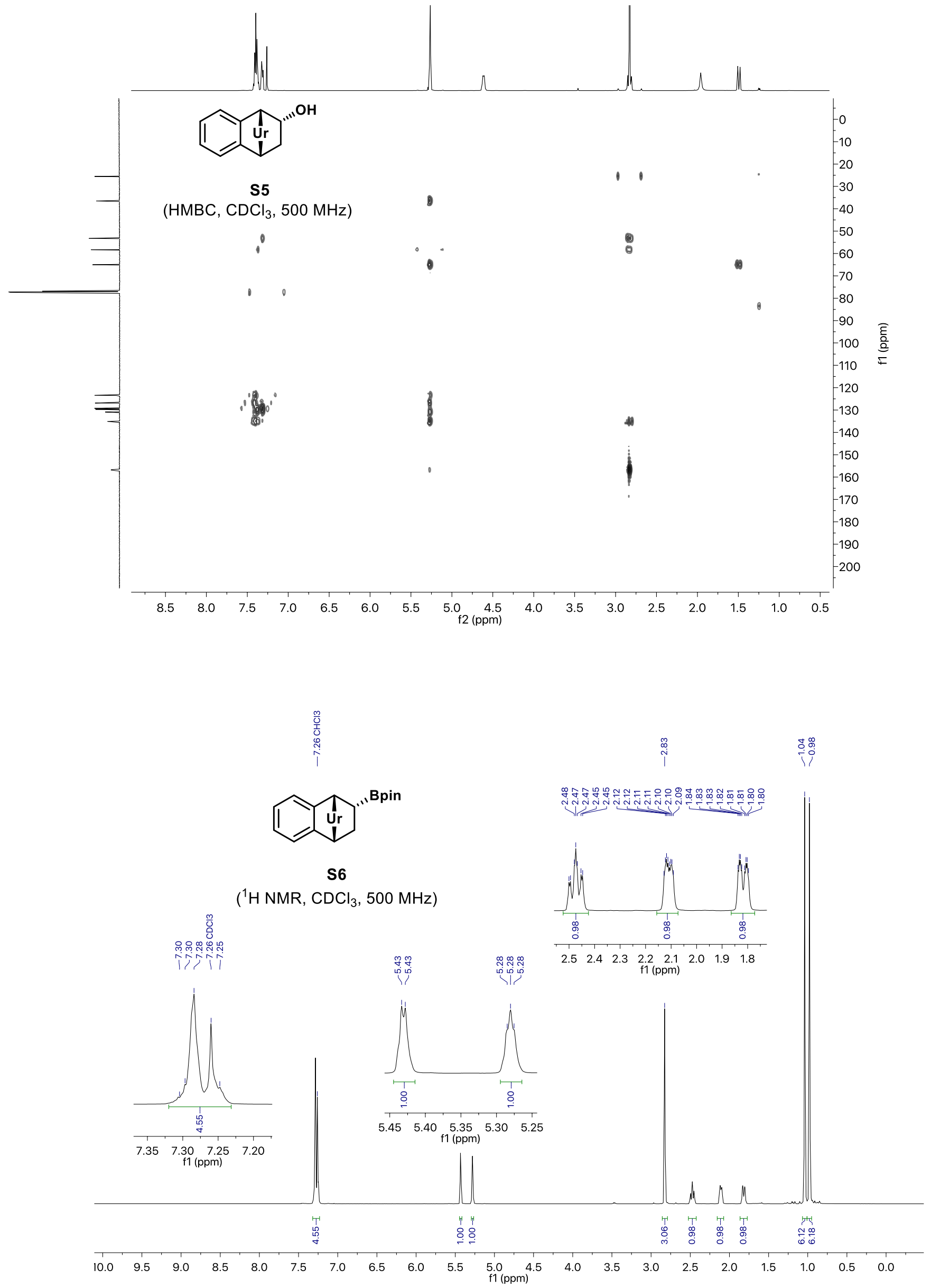

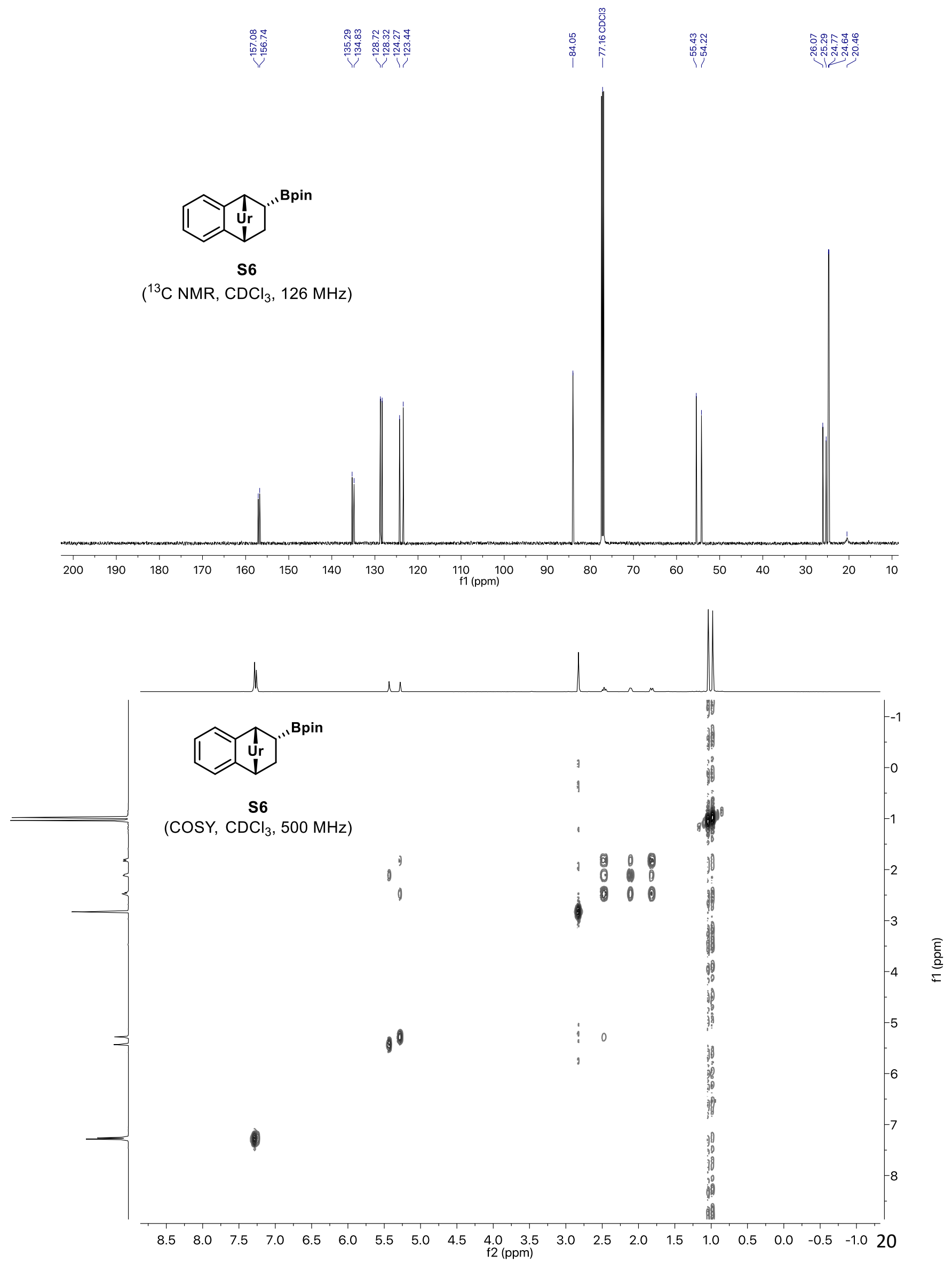

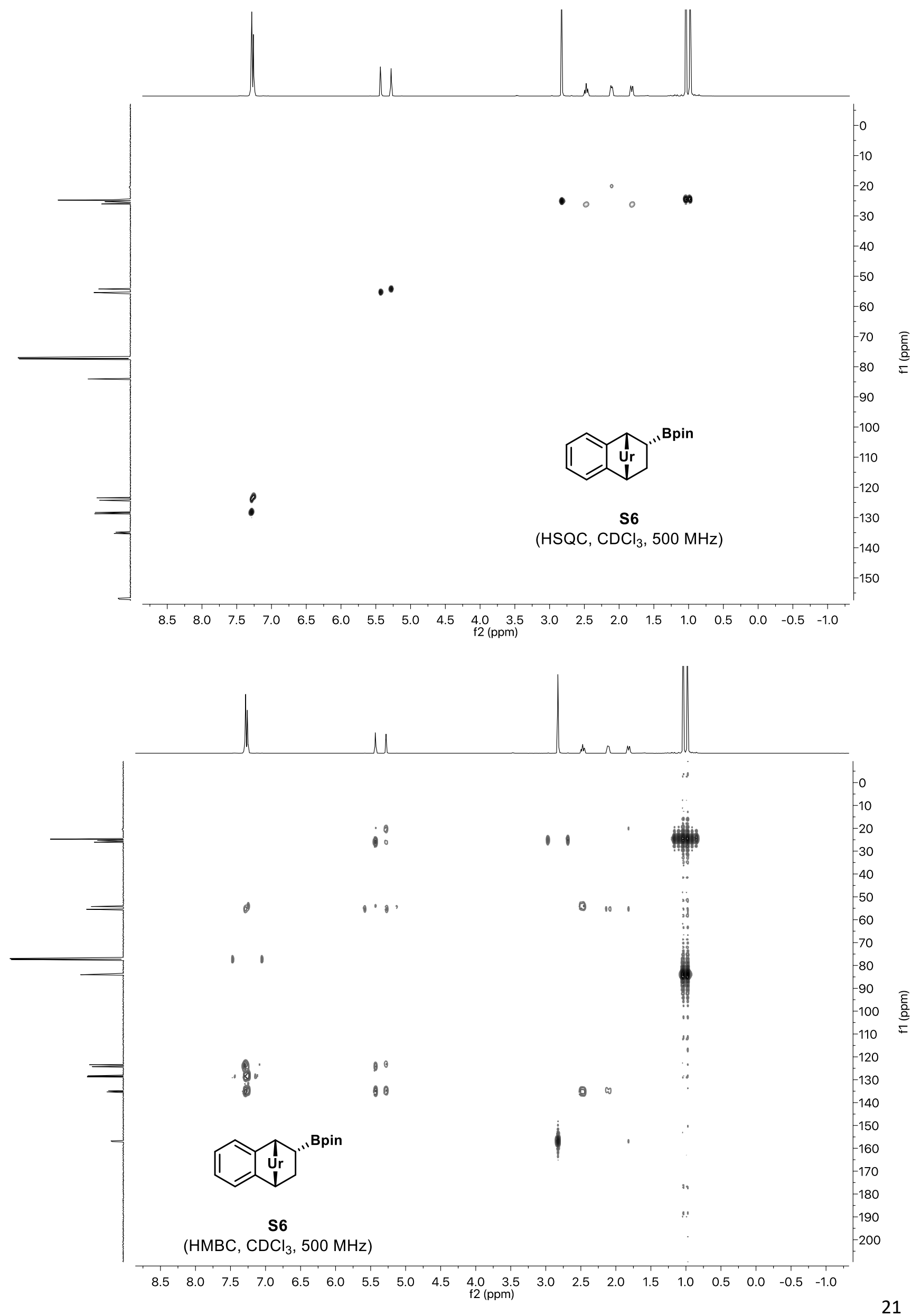


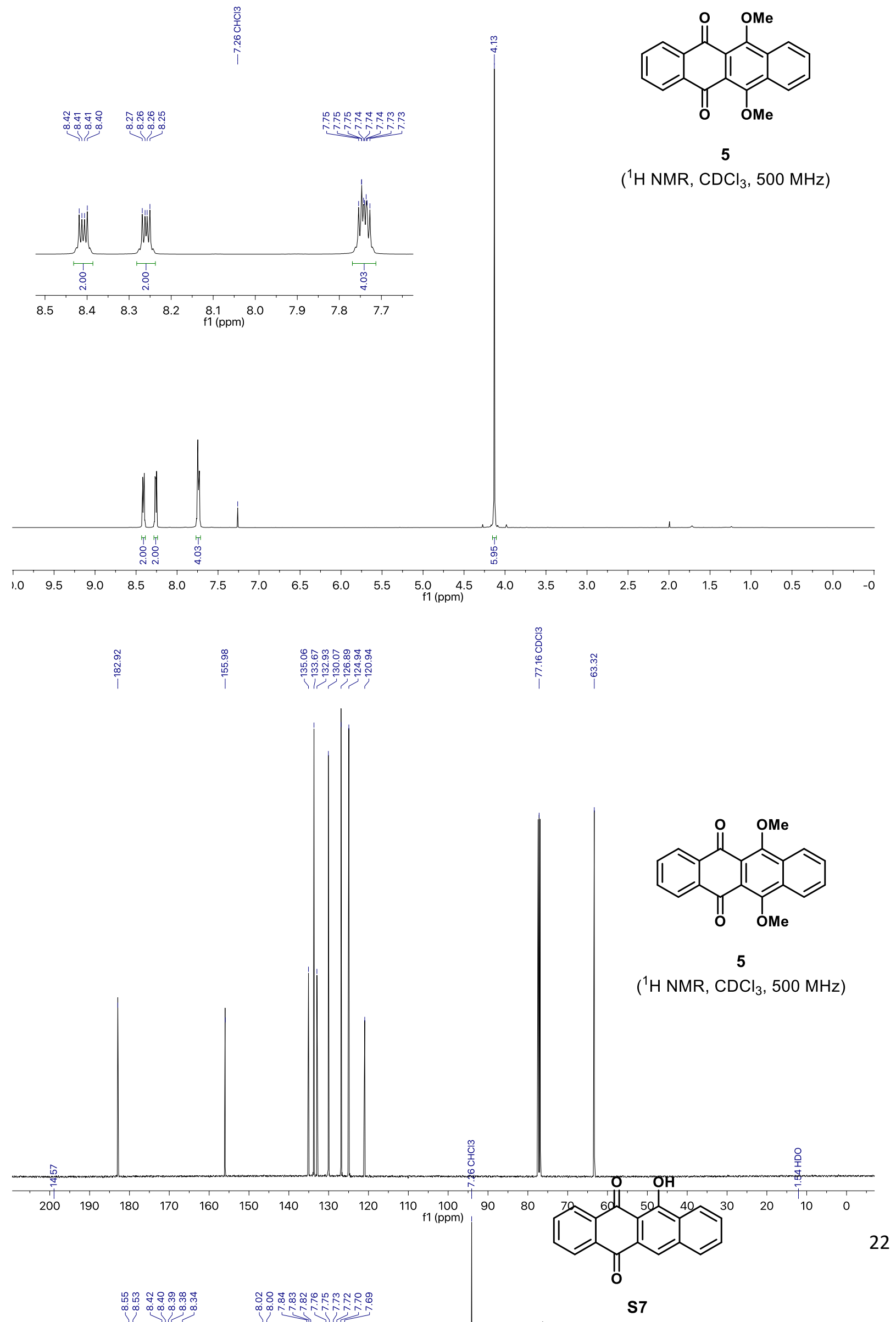




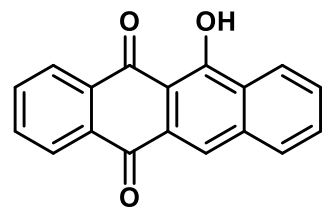

s7

$\left({ }^{13} \mathrm{C}\right.$ NMR, $\left.\mathrm{CDCl}_{3}, 126 \mathrm{MHz}\right)$

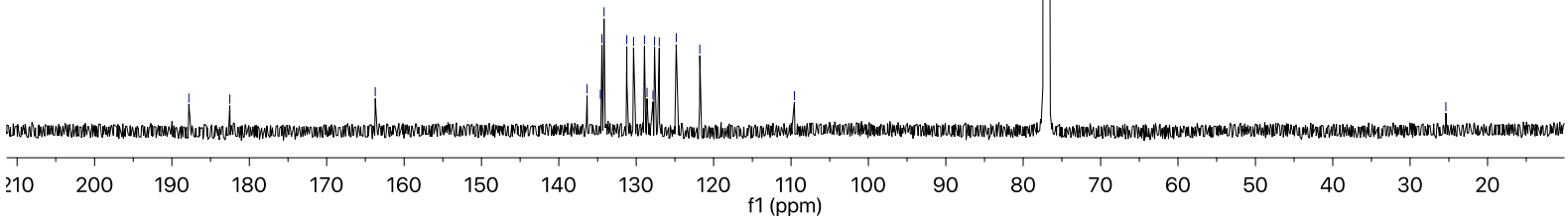



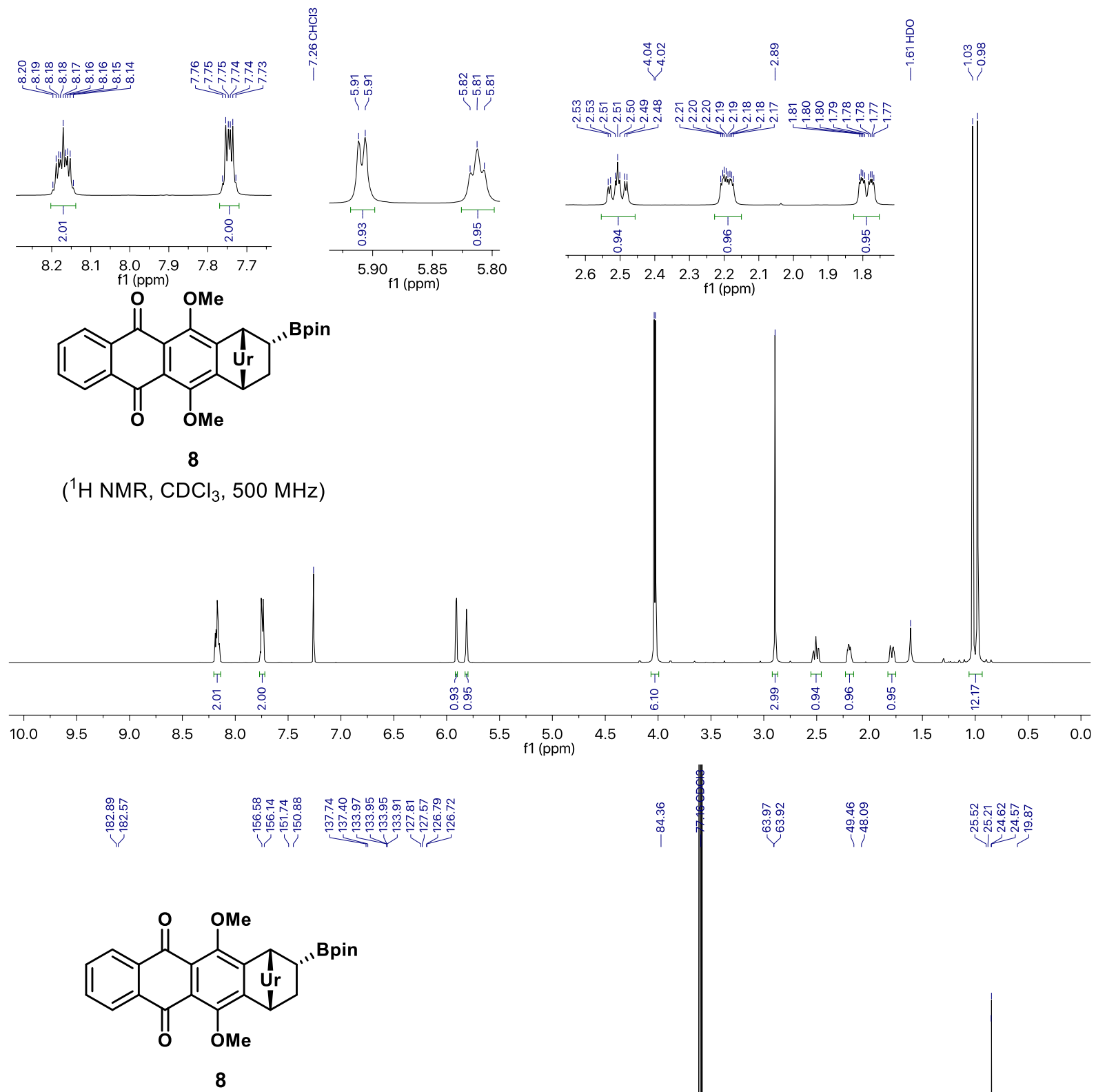

$\left({ }^{13} \mathrm{C} \mathrm{NMR}, \mathrm{CDCl}_{3}, 126 \mathrm{MHz}\right)$

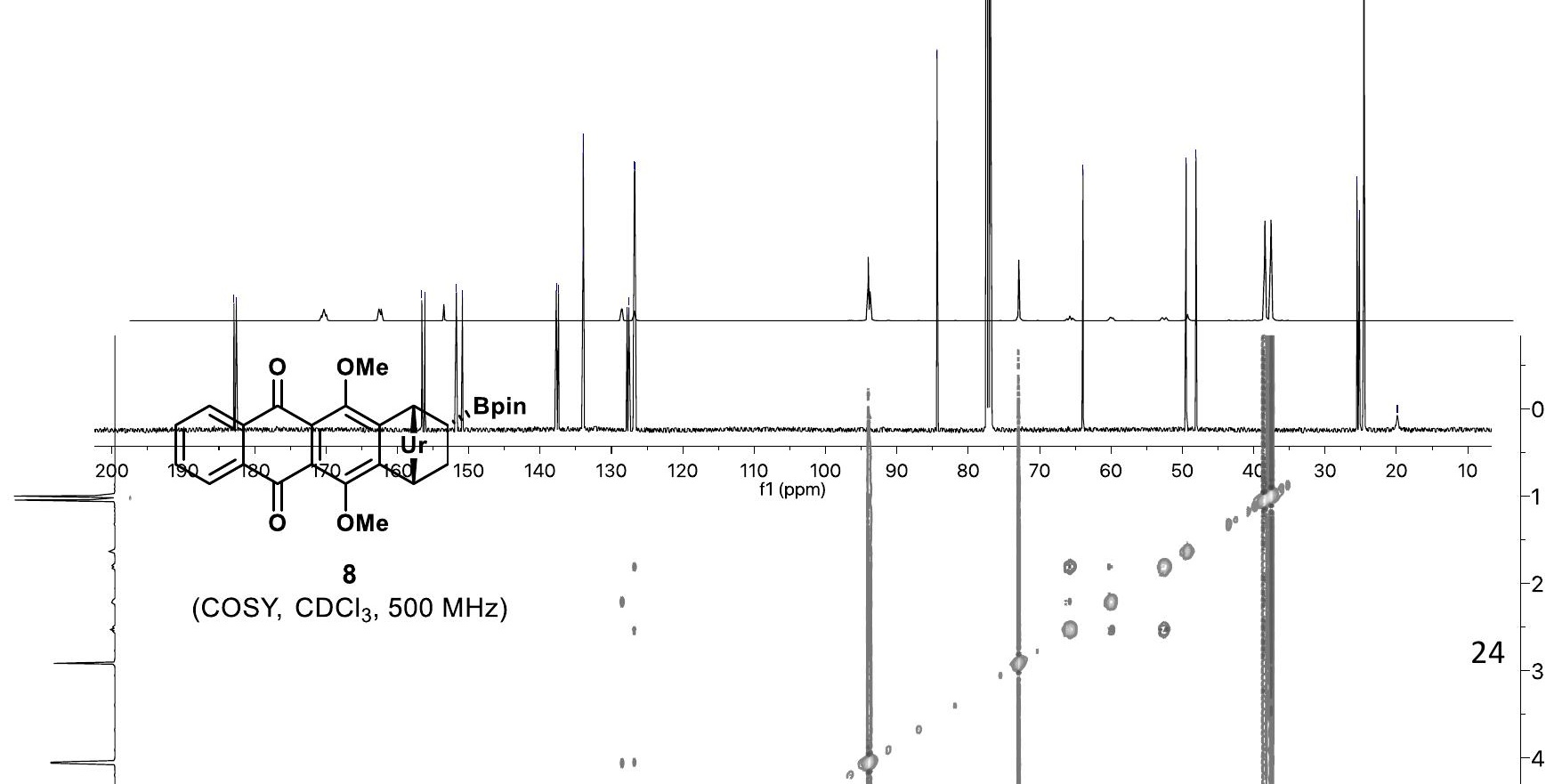




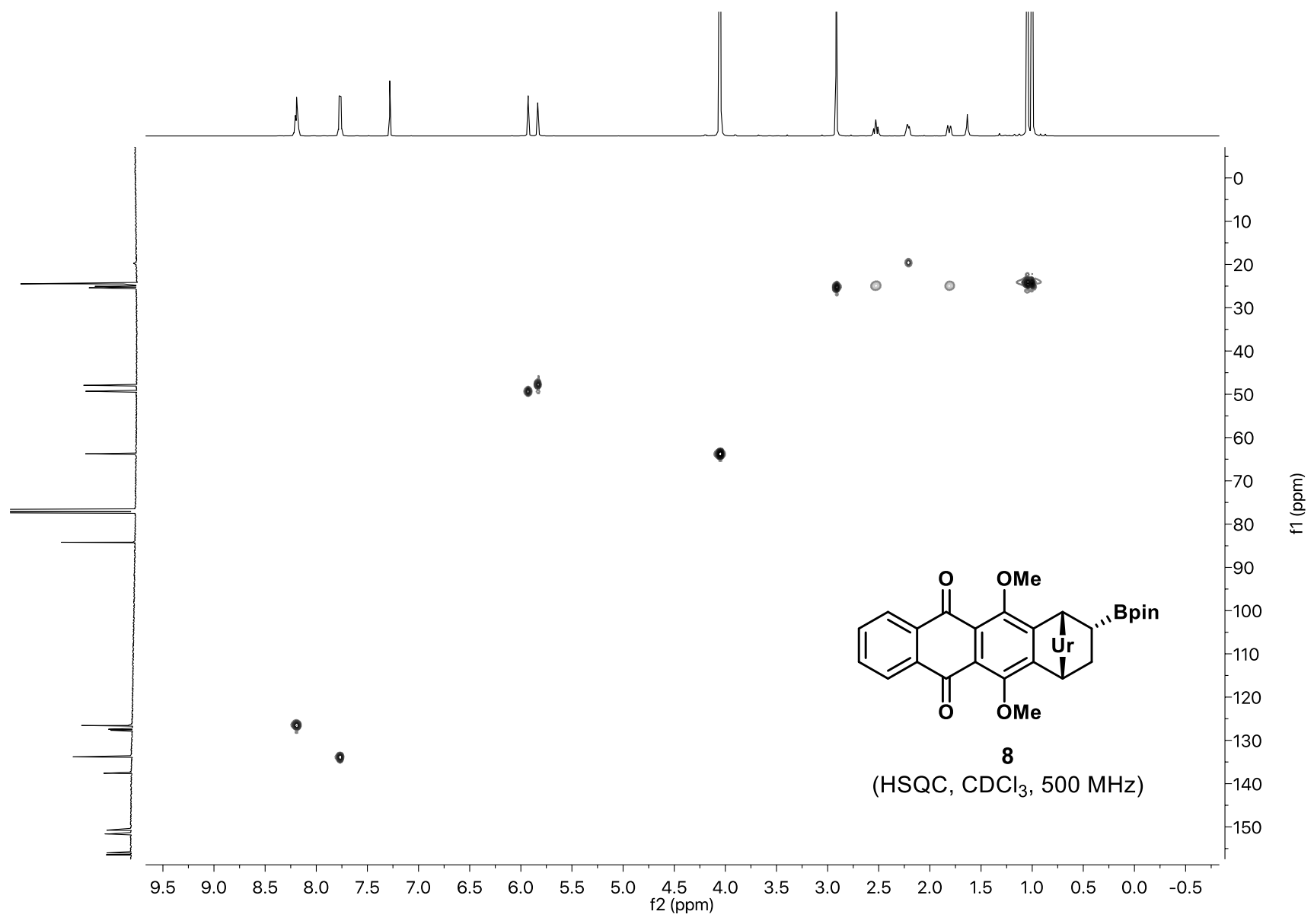



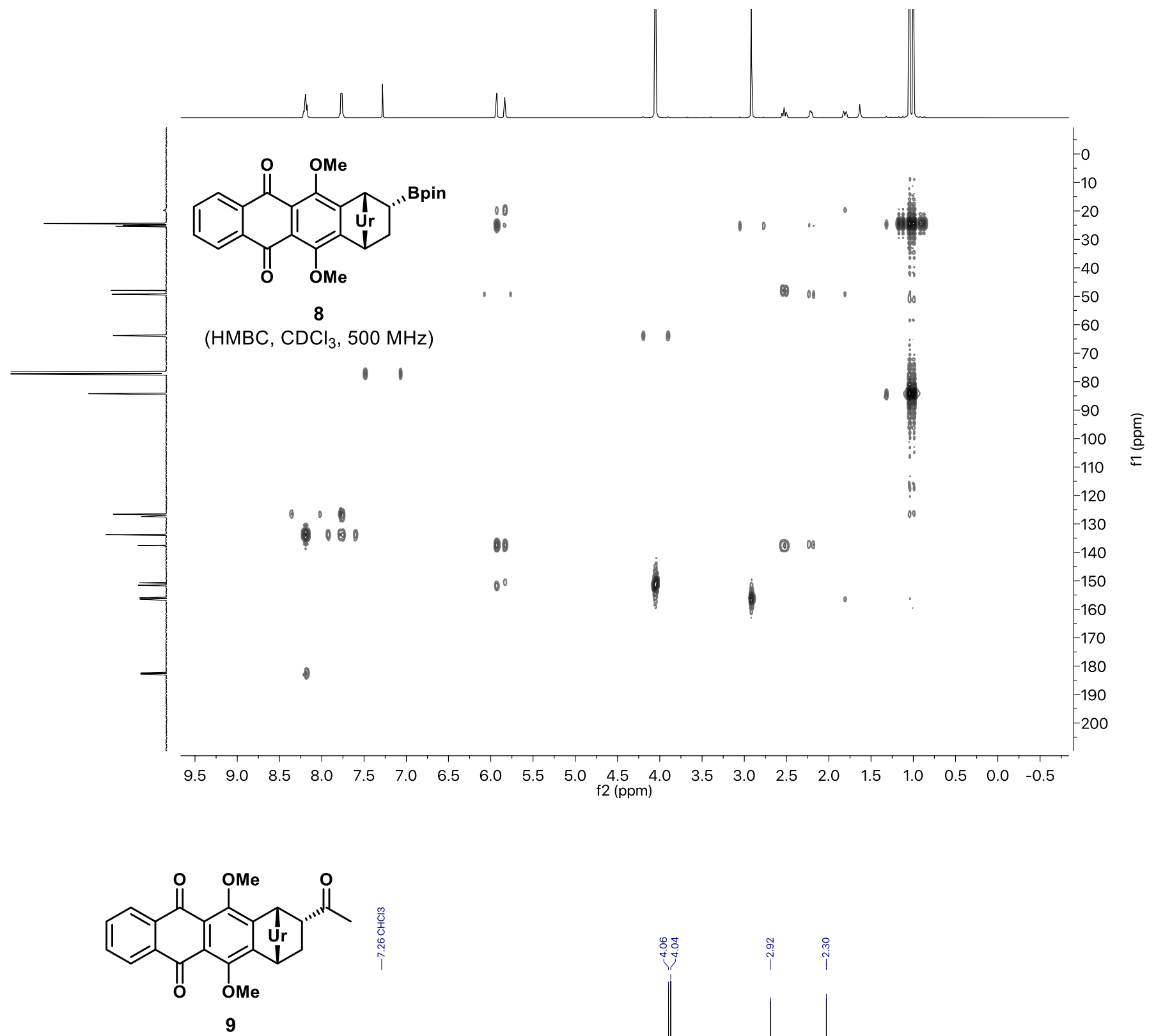

( ${ }^{1} \mathrm{H}$ NMR, $\mathrm{CDCl}_{3}, 500 \mathrm{MHz}$ )

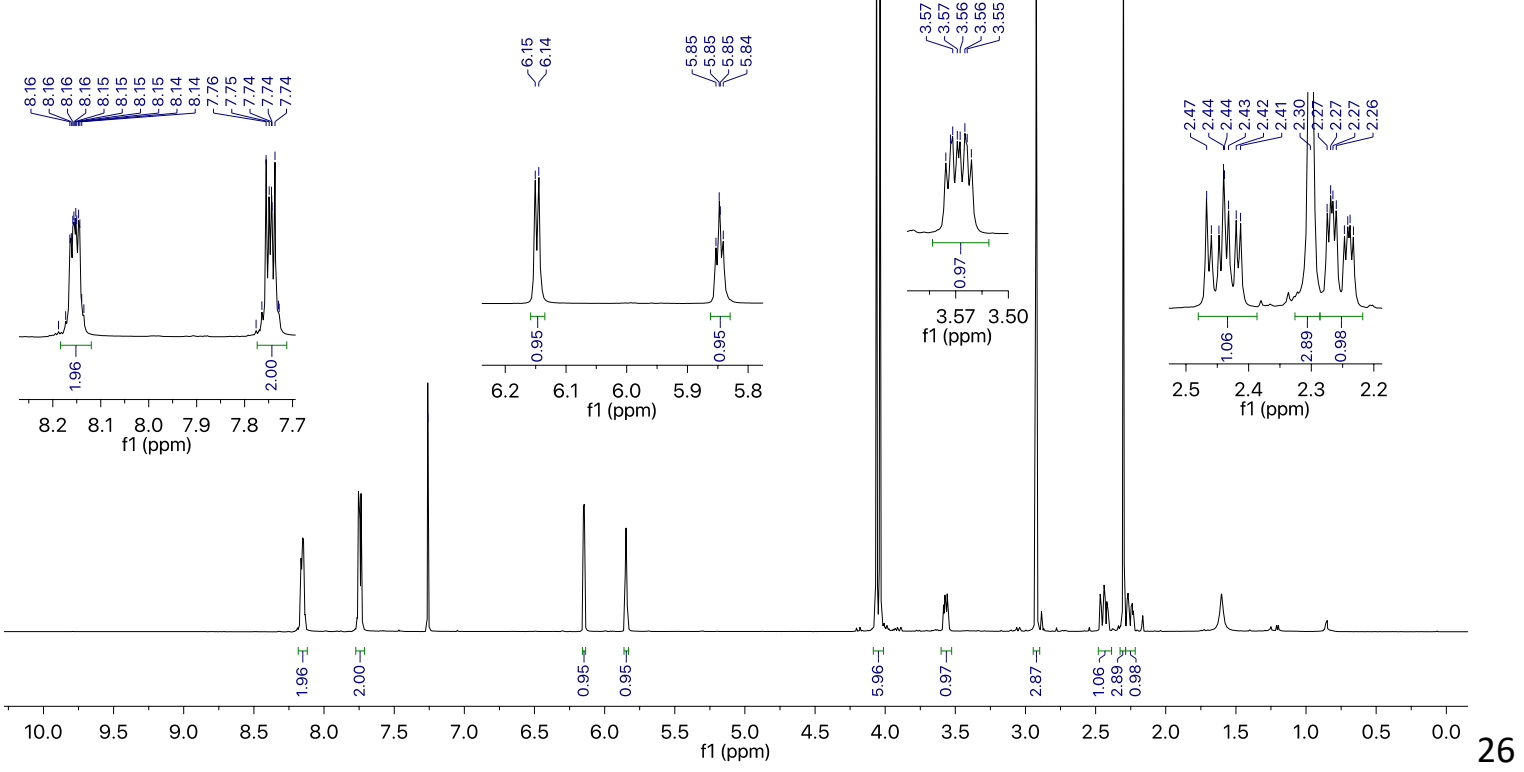



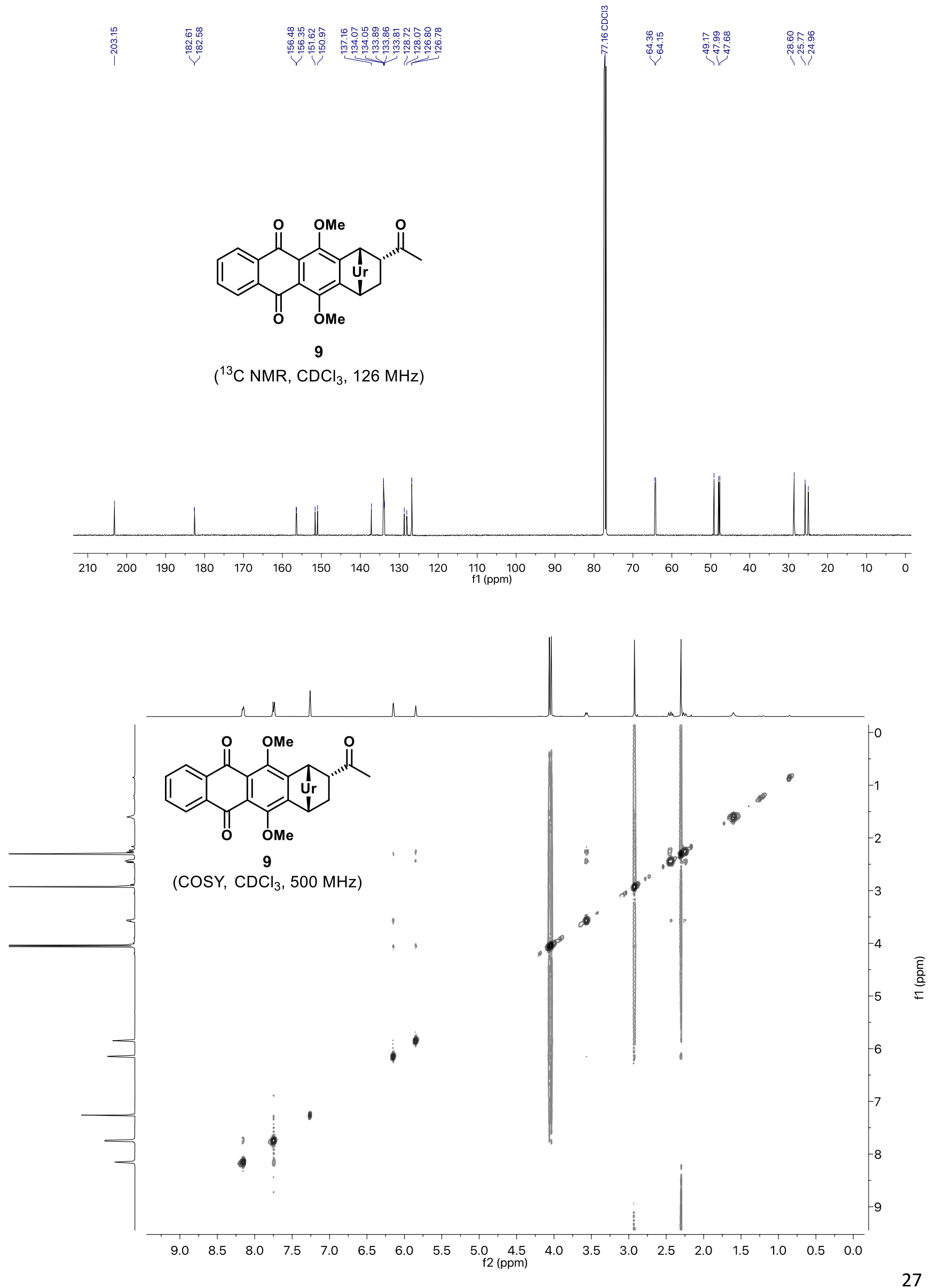


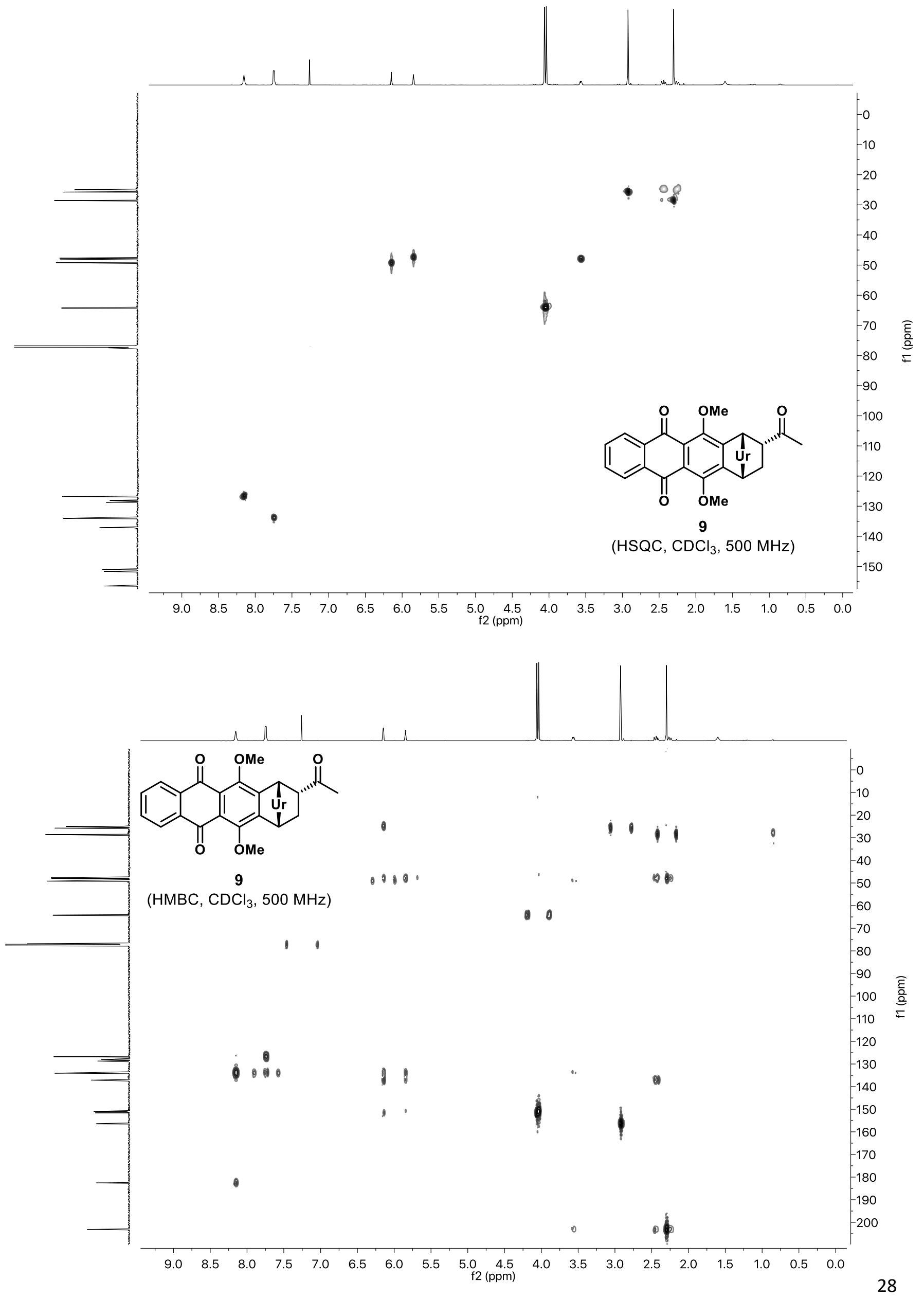



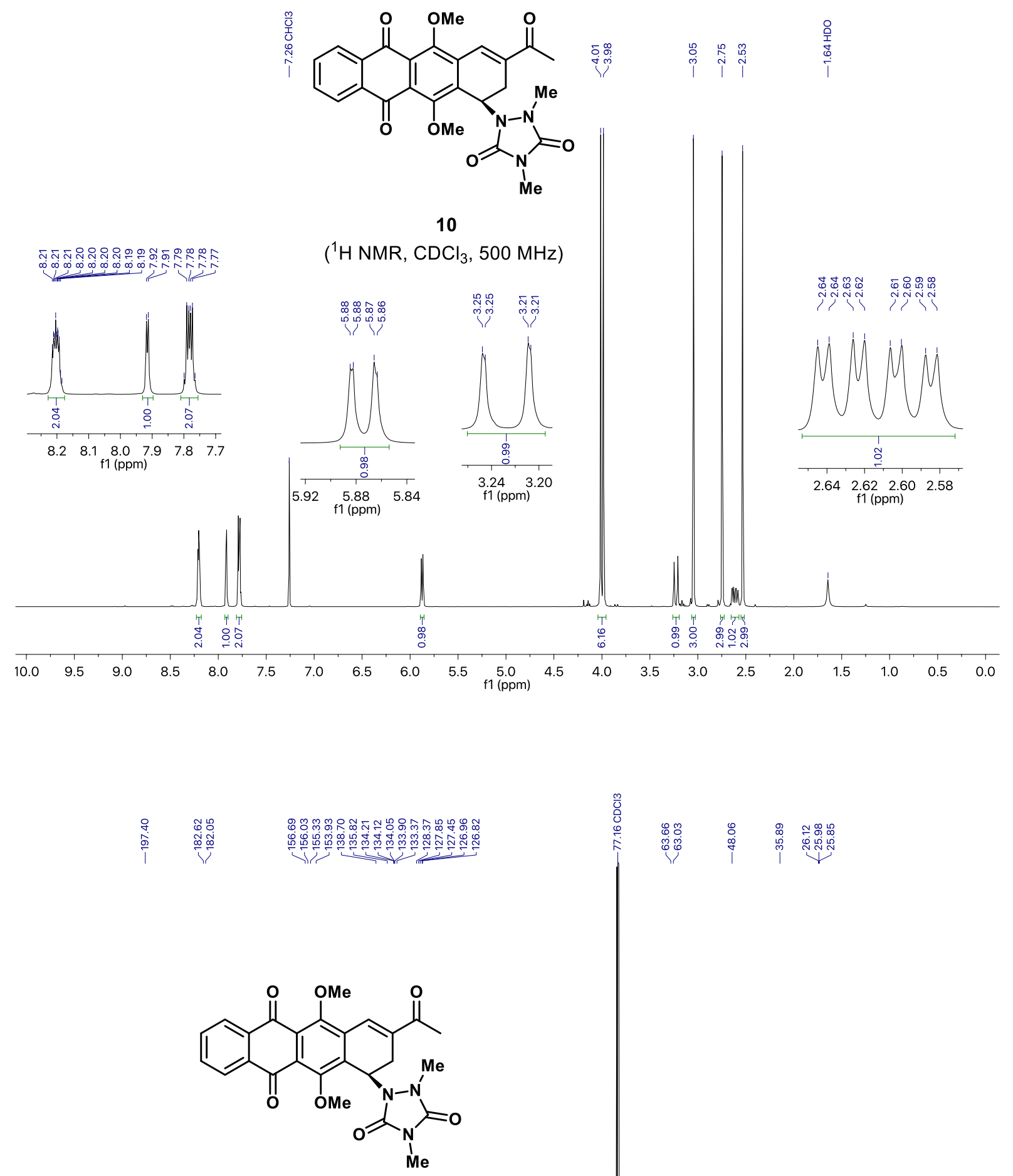

10

$\left({ }^{13} \mathrm{C} \mathrm{NMR}, \mathrm{CDCl}_{3}, 126 \mathrm{MHz}\right)$

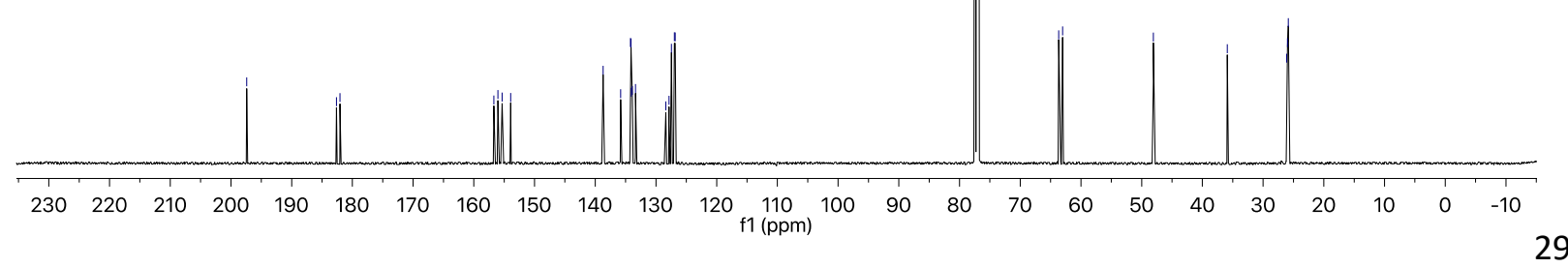



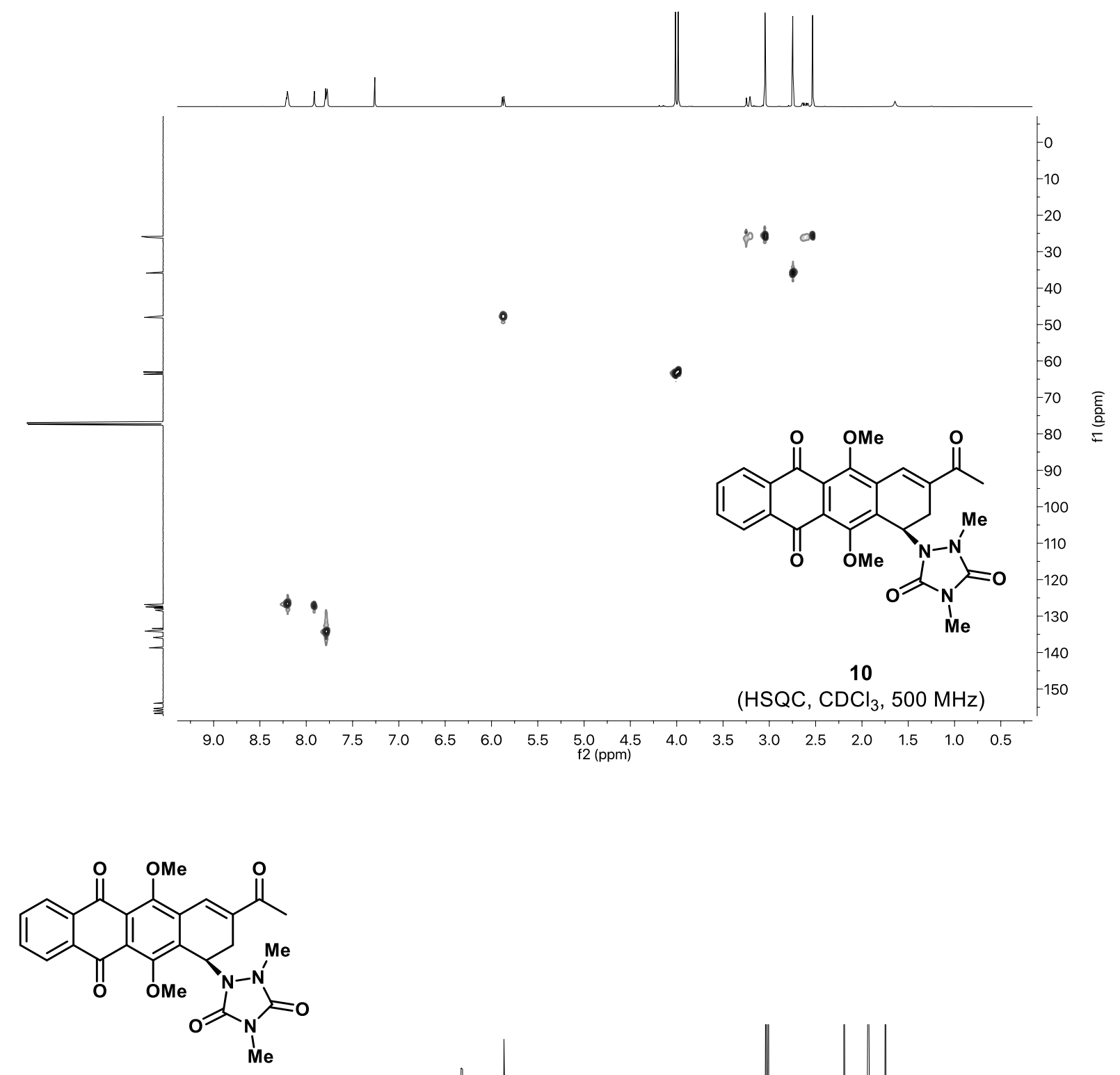

10

(HMBC, $\mathrm{CDCl}_{3}, 500 \mathrm{MHz}$ )

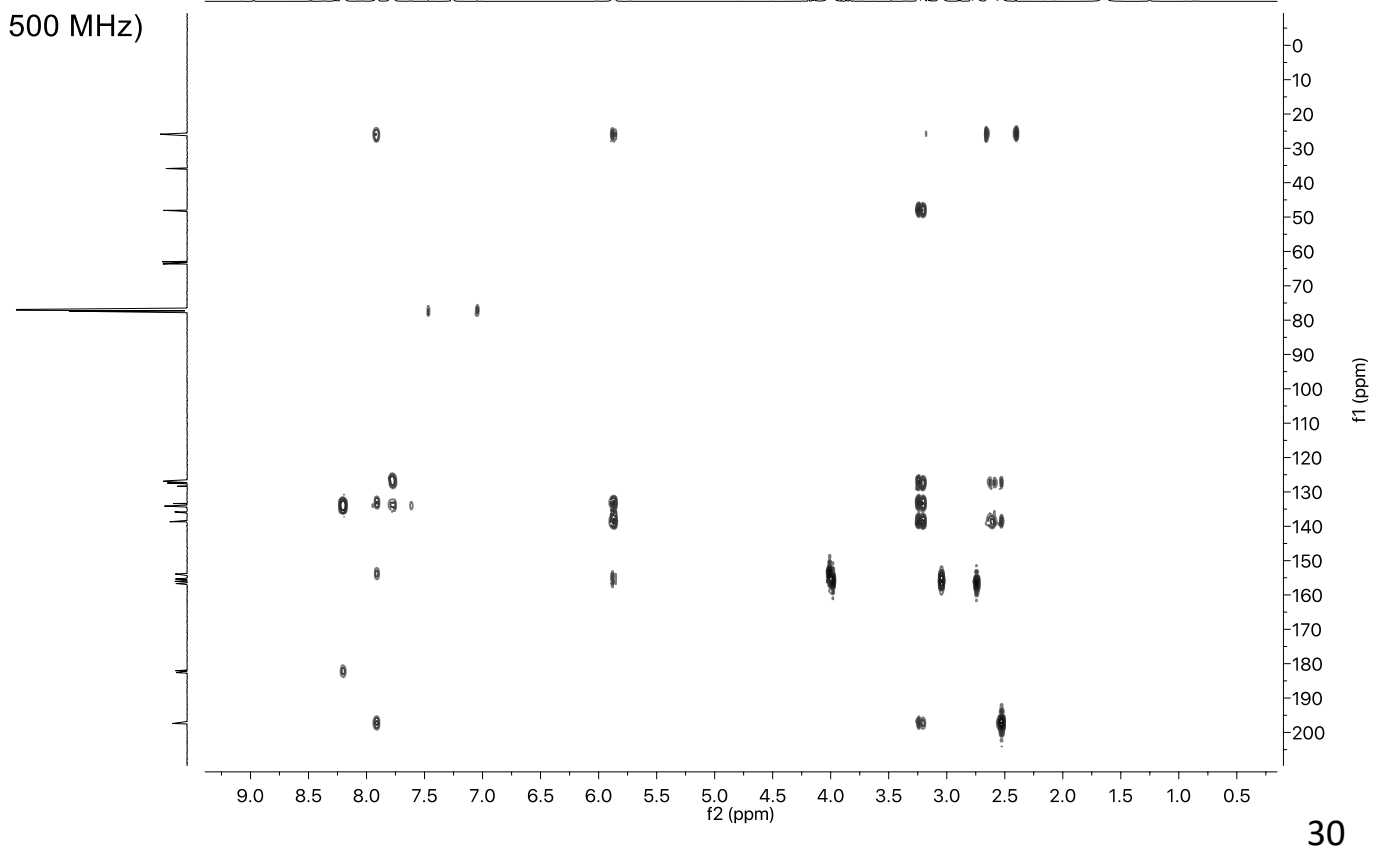



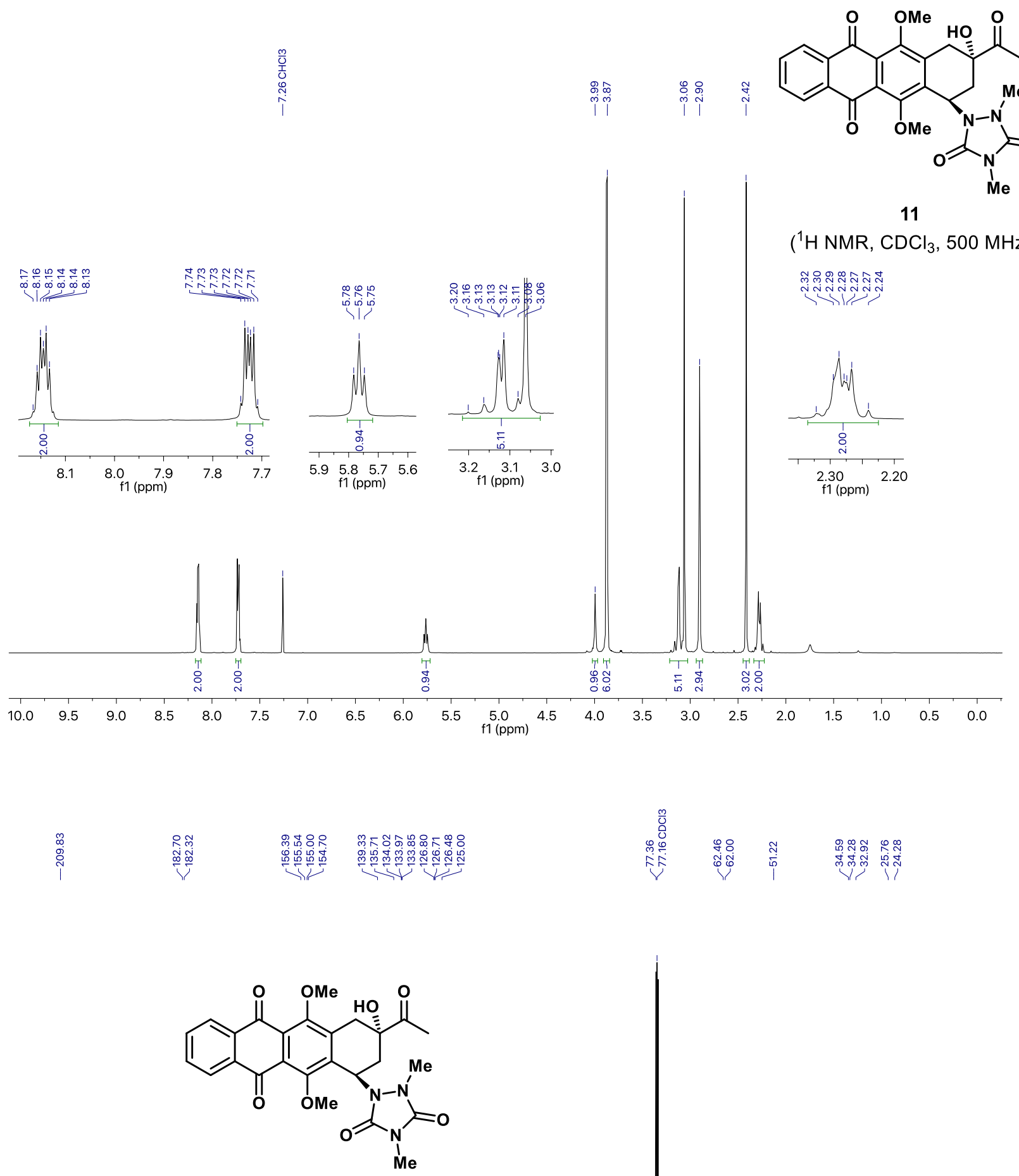

11

$\left({ }^{13} \mathrm{C} \mathrm{NMR}, \mathrm{CDCl}_{3}, 126 \mathrm{MHz}\right)$

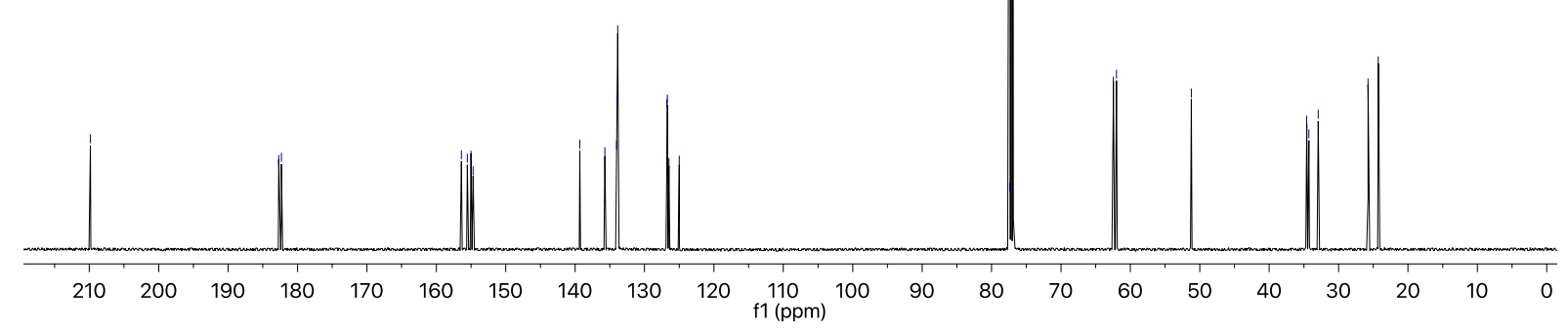




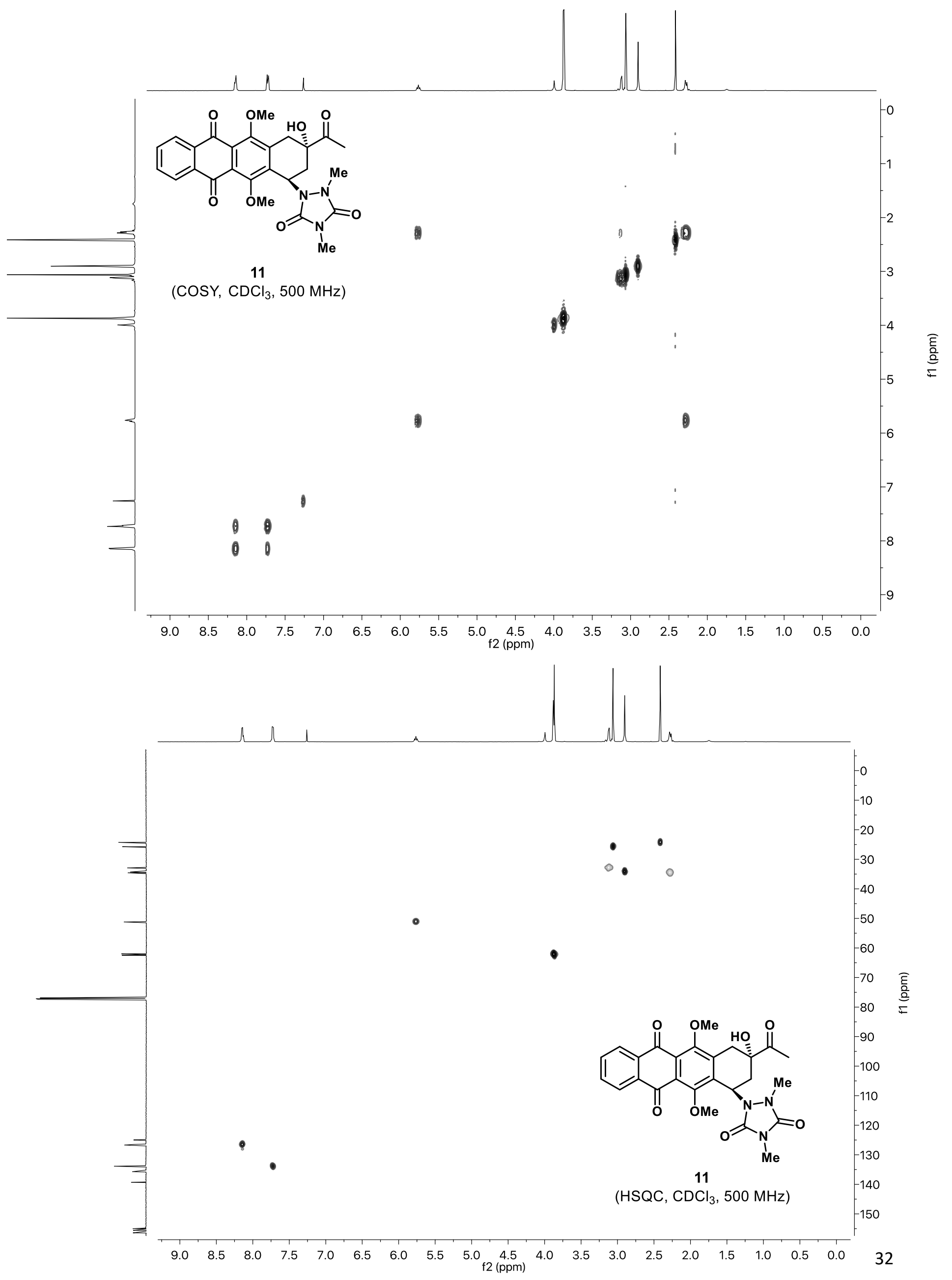



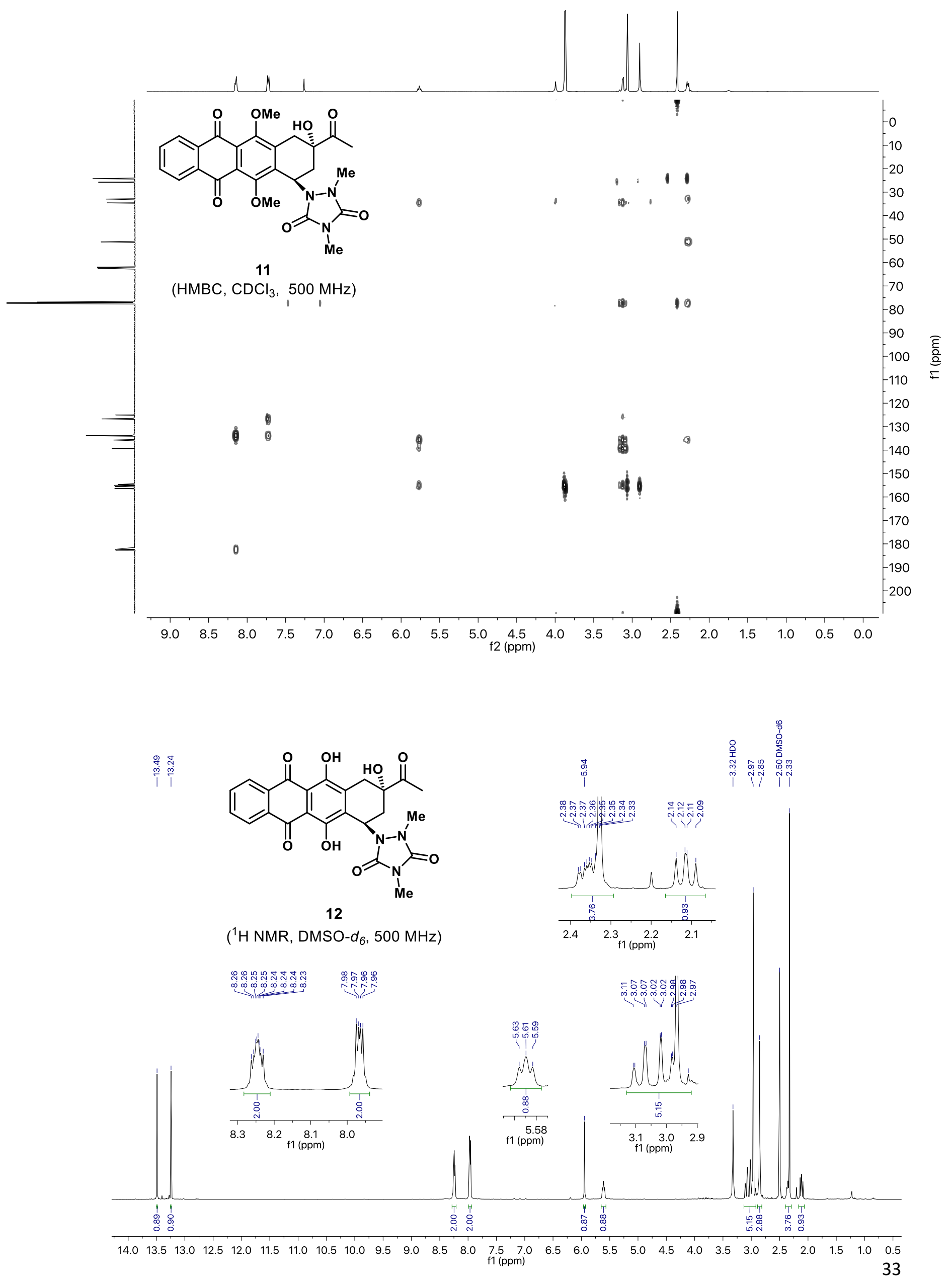


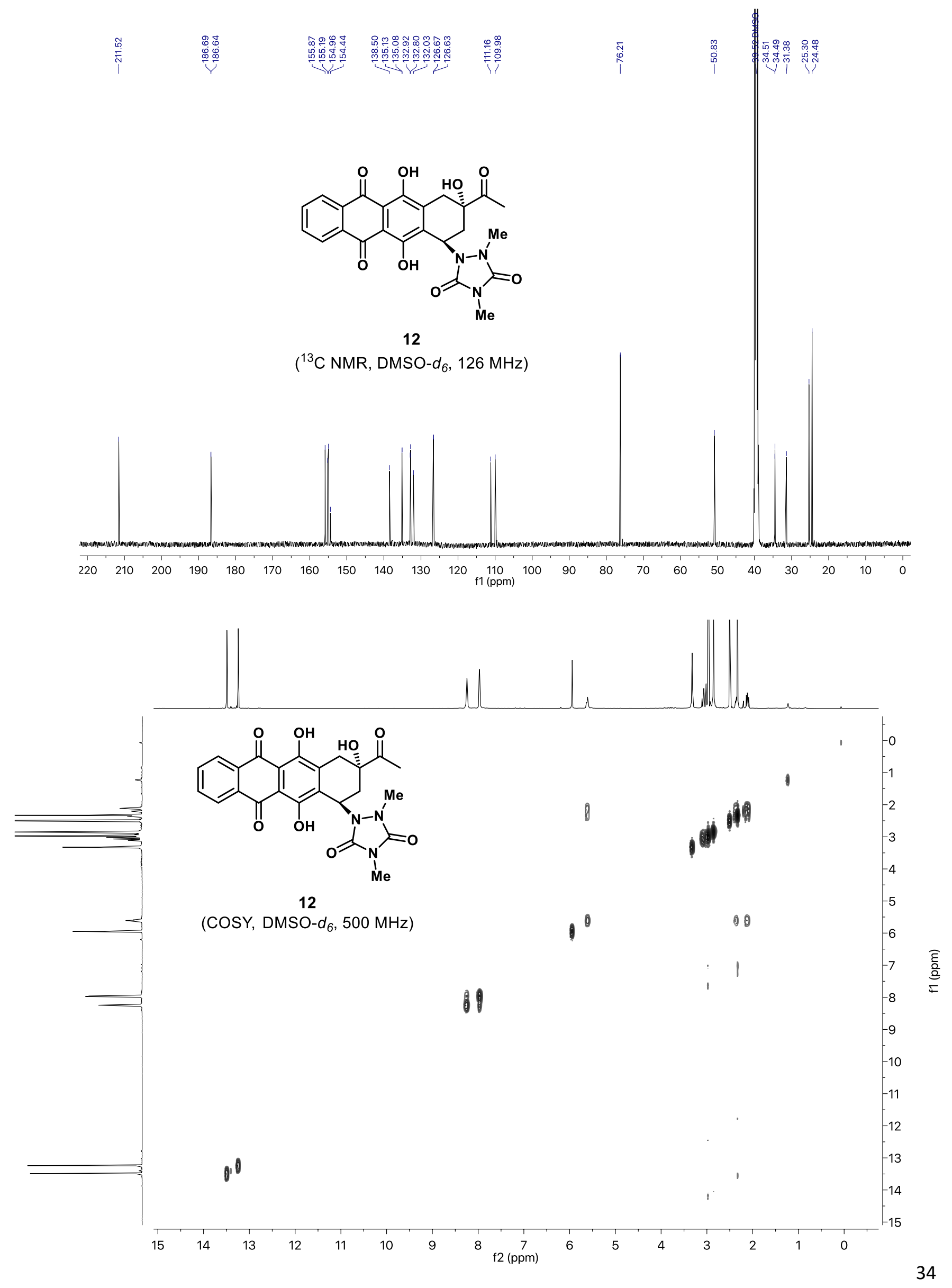



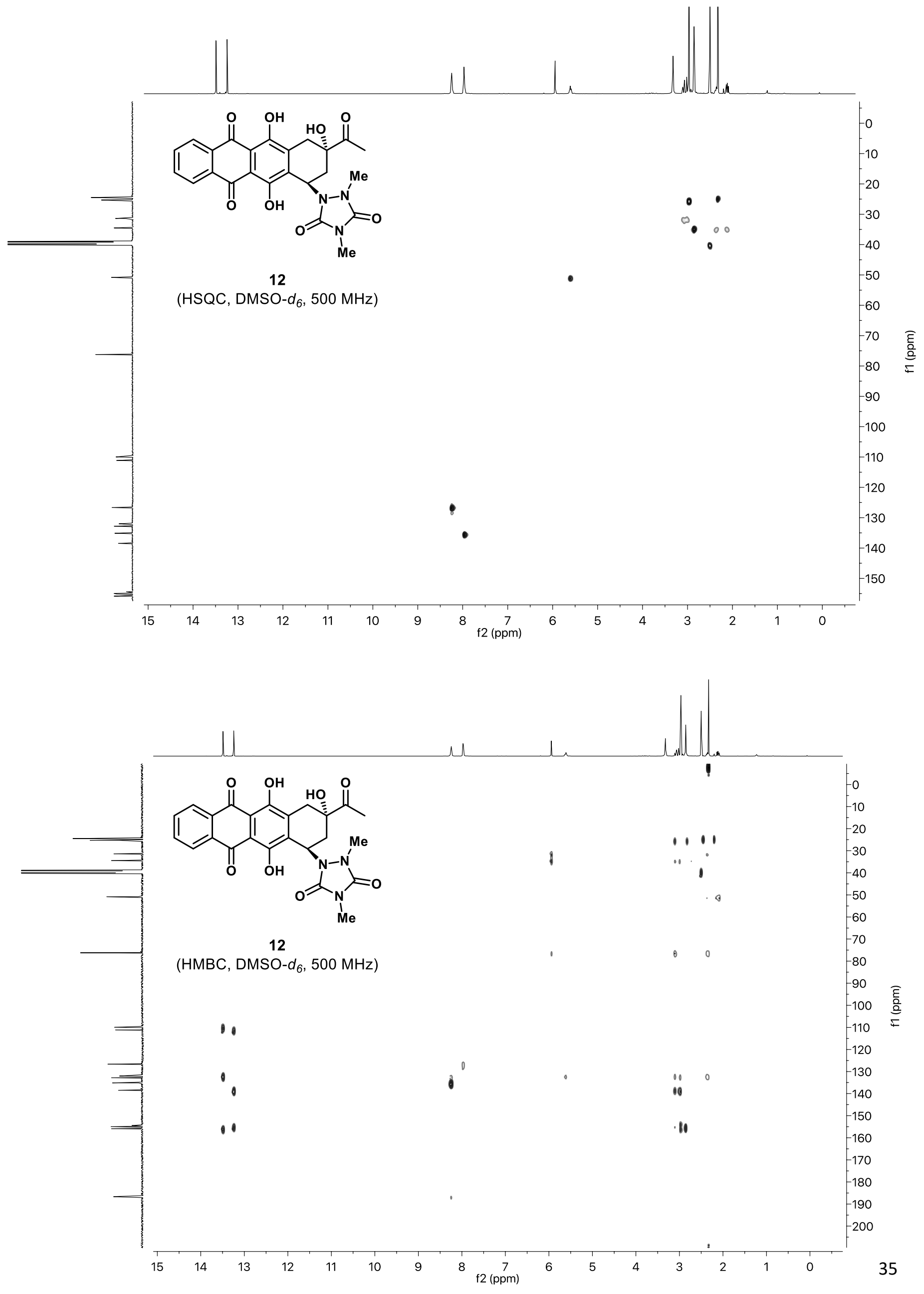
<smiles>CC(=O)C1(O)CCc2c(O)c3c(c(O)c2C1=O)C(=O)c1ccccc1C3=O</smiles>

$\left({ }^{1} \mathrm{H}\right.$ NMR, DMSO- $\left.d_{6}, 500 \mathrm{MHz}\right)$
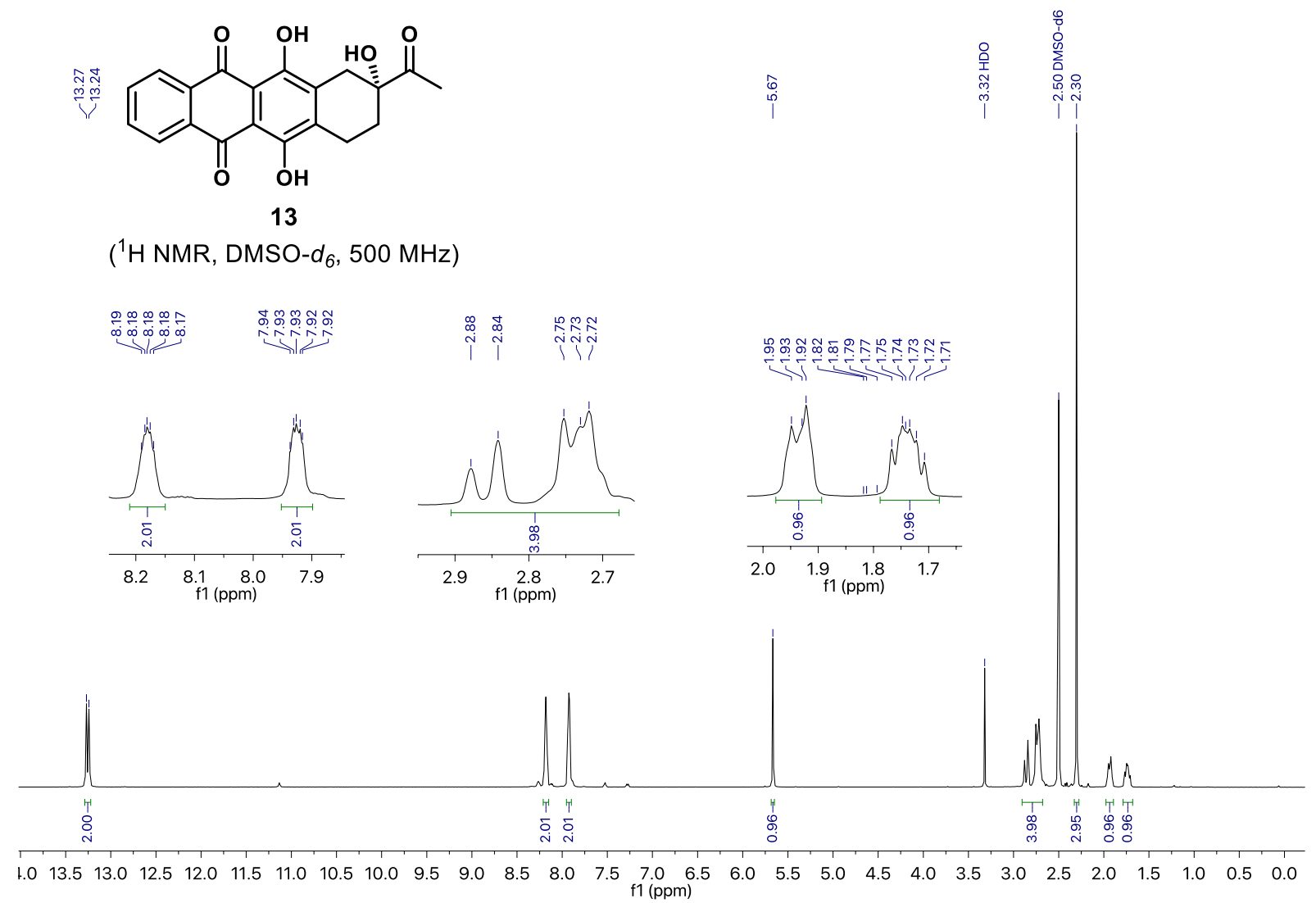

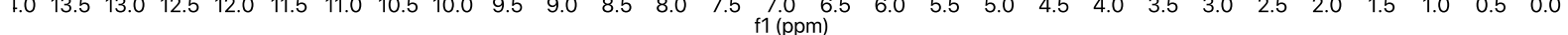

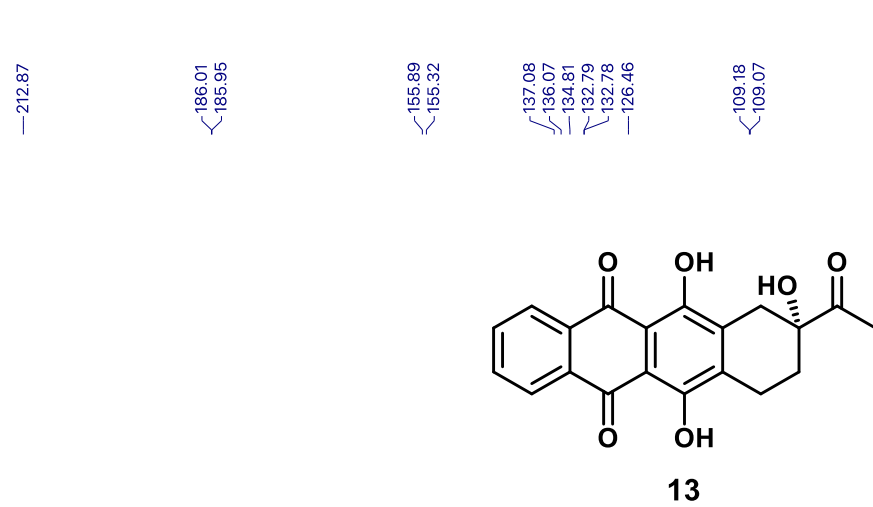

$\left({ }^{13} \mathrm{C}\right.$ NMR, DMSO- $\left.d_{6}, 126 \mathrm{MHz}\right)$

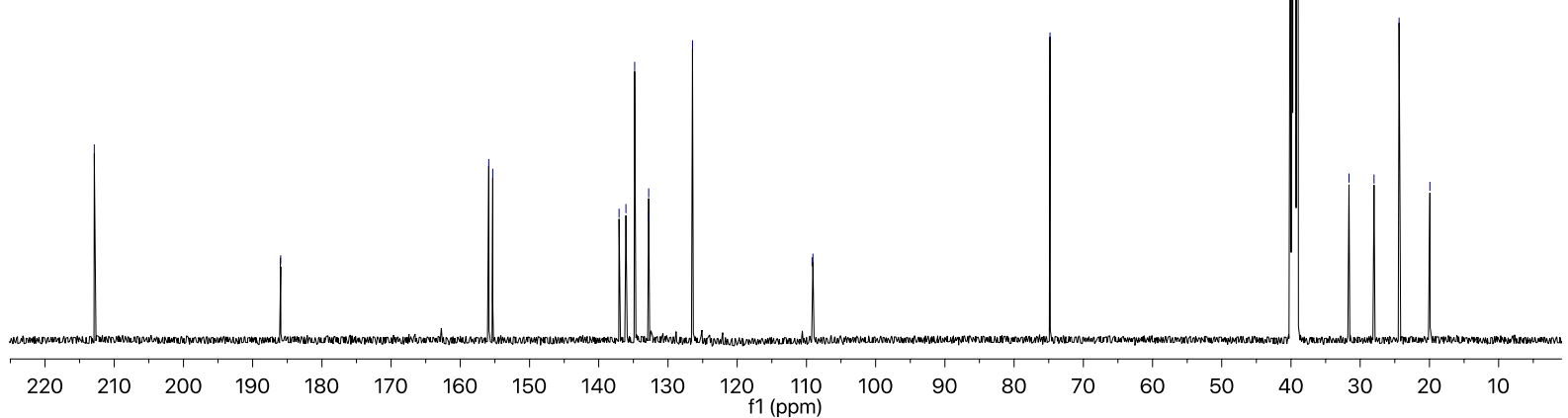



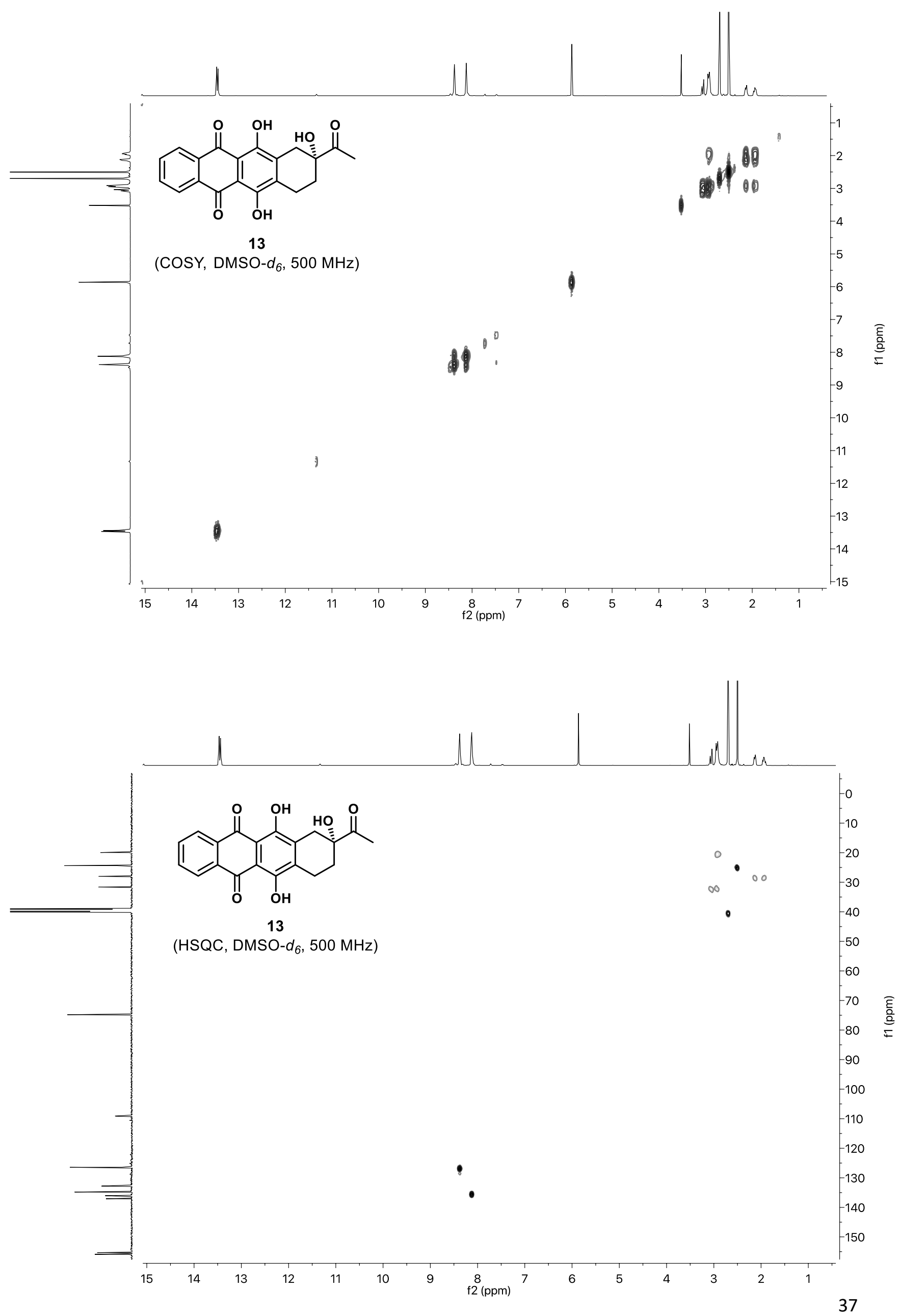


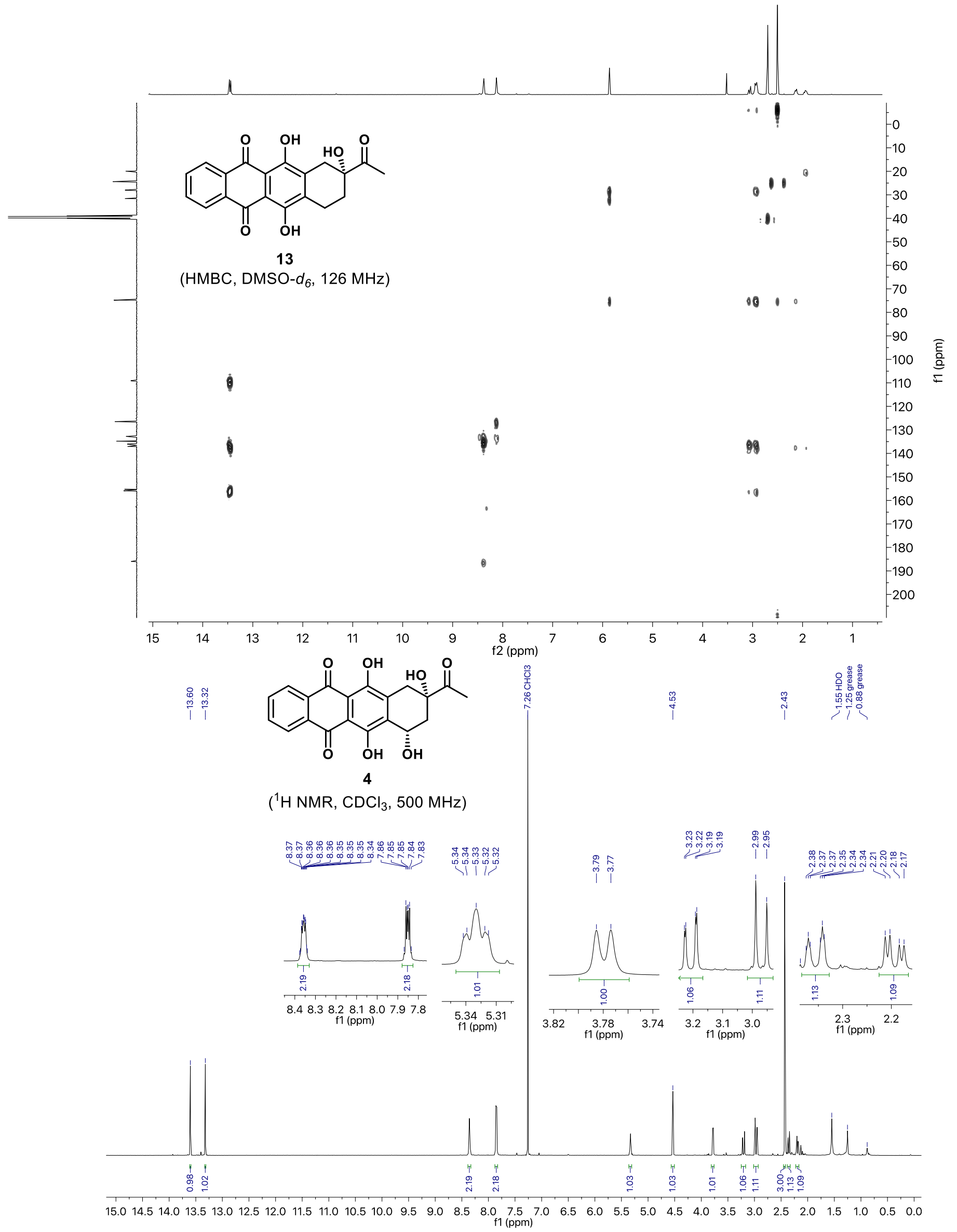



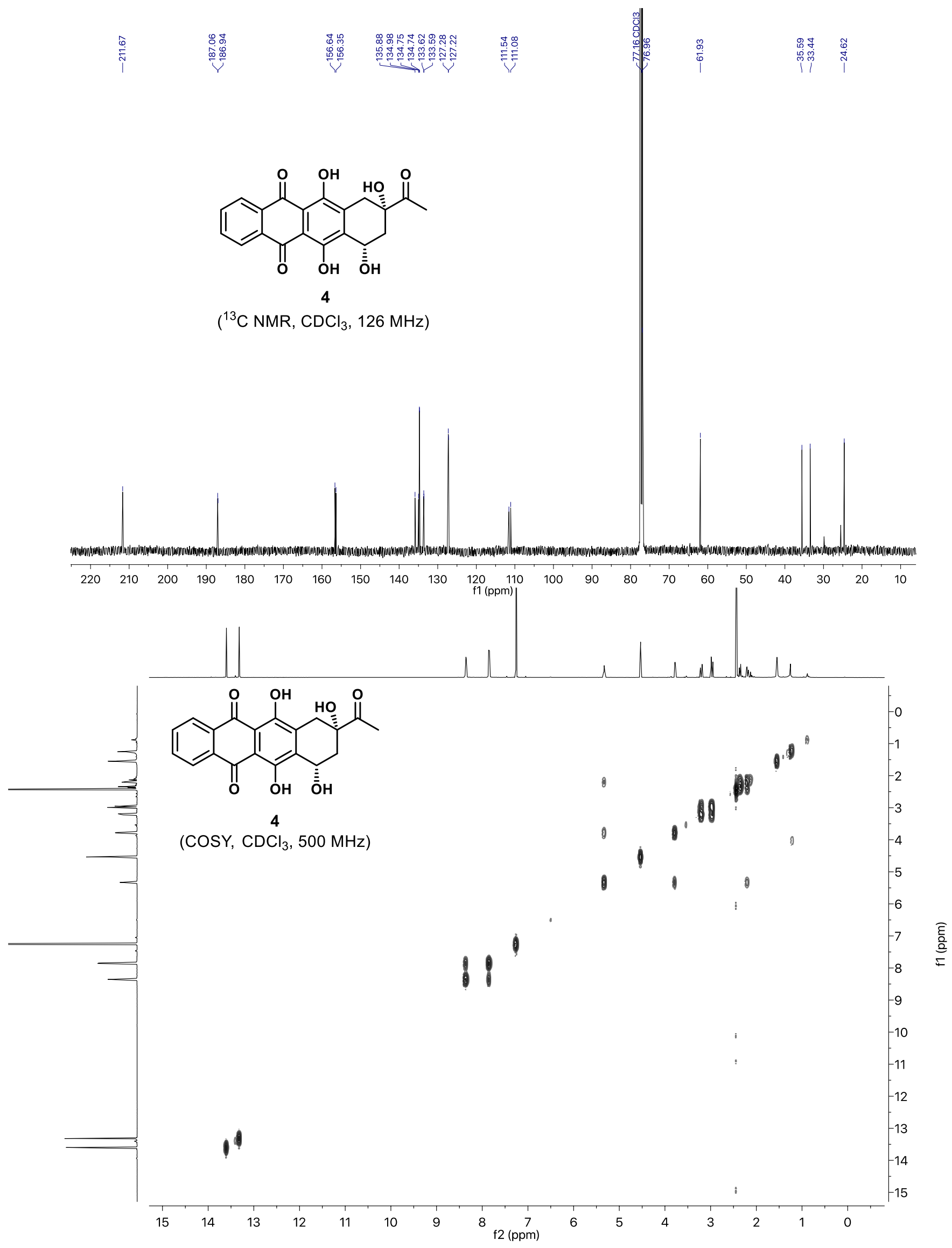


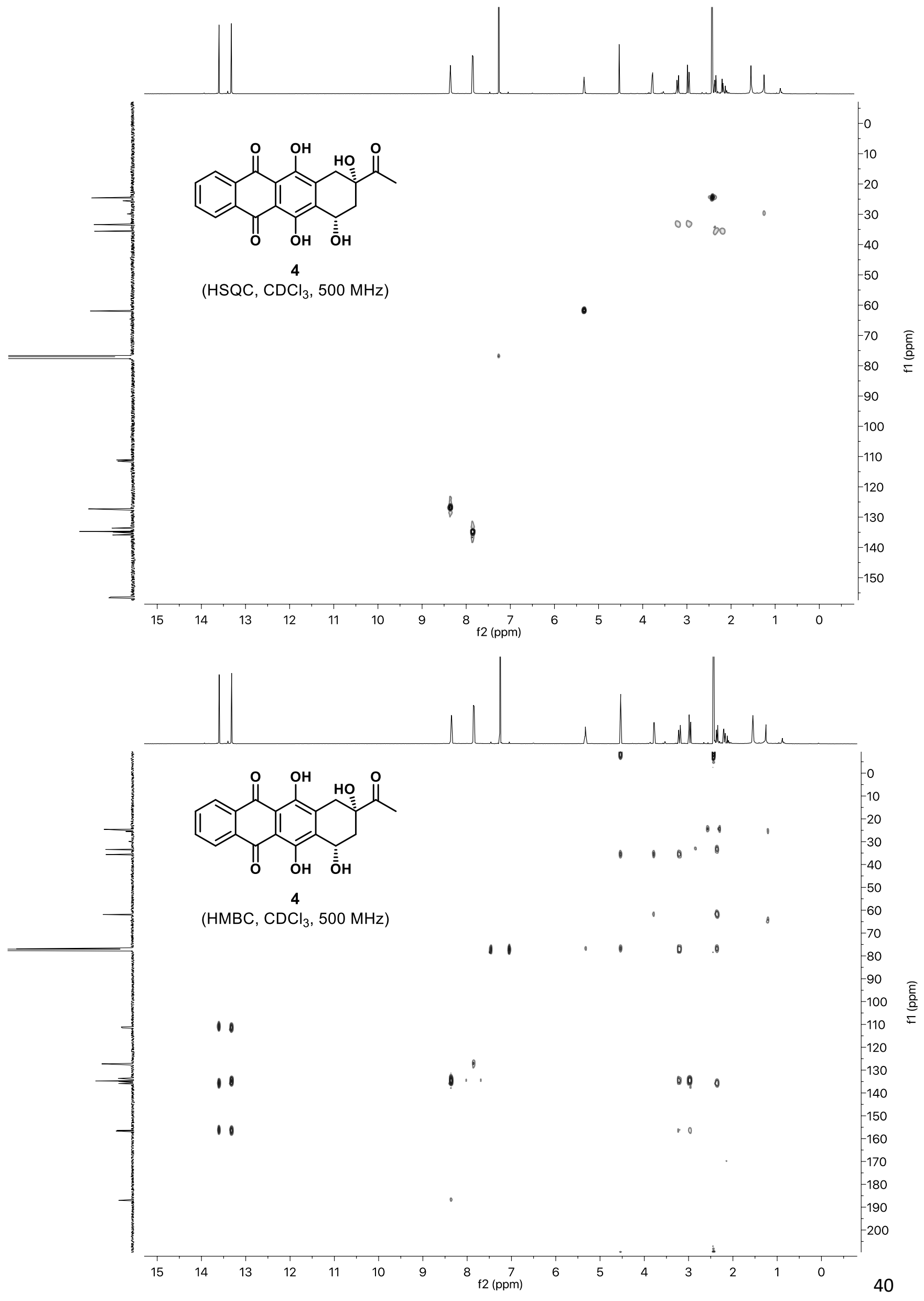




\section{Crystallographic Data}

\section{Crystallographic data for compound 8}

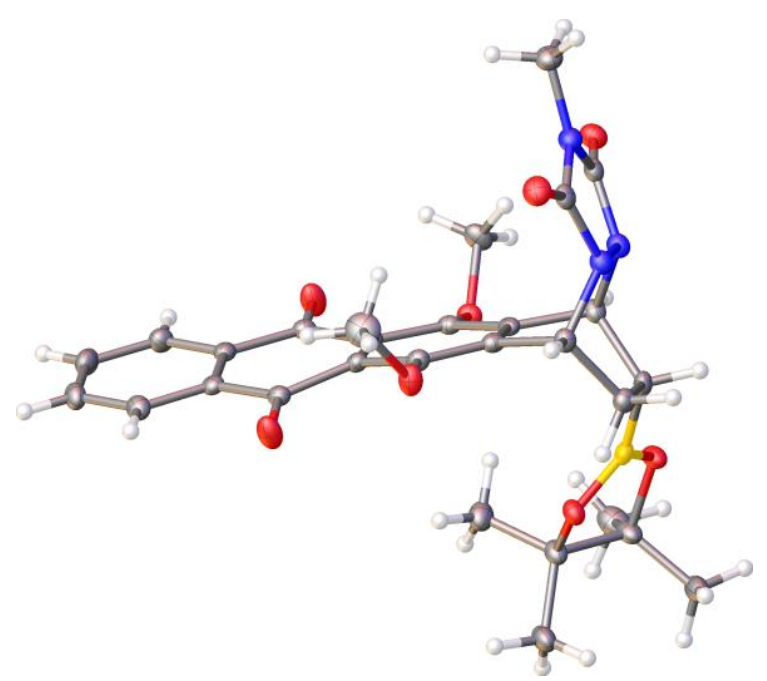

Single crystals of compound $\mathbf{8}$ were obtained by slow recrystallization from diethyl ether. A suitable crystal was selected and diffraction data were collected on a Bruker D8 Venture/Photon 100 diffractometer. The crystal was kept at $100.2 \mathrm{~K}$ during data collection.

Identification code

Empirical formula

Formula weight

Temperature

Radiation

Crystal system

Space group

Unit cell dimensions

Volume

$\mathrm{Z}$

Density (calculated)

Absorption coefficient

$\mathrm{F}(000)$

Crystal size

Theta range for data collection
CCDC 1910638

$\mathrm{C}_{29} \mathrm{H}_{30} \mathrm{BN}_{3} \mathrm{O}_{8}$

559.37

100(2) K

$\mathrm{CuK} \alpha(\lambda=1.54178)$

Monoclinic

$\mathrm{P} 21 / \mathrm{n}$

$\mathrm{a}=9.4519(2) \AA \quad \alpha=90^{\circ}$.

$\mathrm{b}=16.7889(3) \AA \quad \beta=101.6745(7)^{\circ}$.

$\mathrm{c}=16.9365(3) \AA \quad \gamma=90^{\circ}$.

2632.00(9) $\AA^{3}$

4

$1.412 \mathrm{Mg} / \mathrm{m}^{3}$

$0.854 \mathrm{~mm}^{-1}$

1176

$0.169 \times 0.063 \times 0.060 \mathrm{~mm}^{3}$

3.746 to $68.373^{\circ}$. 
Index ranges

Reflections collected

Independent reflections

Completeness to theta $=67.679^{\circ}$

Absorption correction

Max. and min. transmission

Refinement method

Data / restraints / parameters

Goodness-of-fit on $\mathrm{F}^{2}$

Final $\mathrm{R}$ indices [I $>2 \operatorname{sigma}(\mathrm{I})]$

$\mathrm{R}$ indices (all data)

Extinction coefficient

Largest diff. peak and hole $-10<=\mathrm{h}<=11,-19<=\mathrm{k}<=20,-20<=\mathrm{l}<=20$

29258

$4835[\mathrm{R}(\mathrm{int})=0.0508]$

$100.0 \%$

Semi-empirical from equivalents

0.7531 and 0.7005

Full-matrix least-squares on $\mathrm{F}^{2}$

4835 / 242 / 454

1.034

$\mathrm{R} 1=0.0360, \mathrm{wR} 2=0.0775$

$\mathrm{R} 1=0.0490, \mathrm{wR} 2=0.0833$

$\mathrm{n} / \mathrm{a}$

0.277 and -0.222 e. $\AA^{-3}$

\section{Crystallographic data for compound S6}

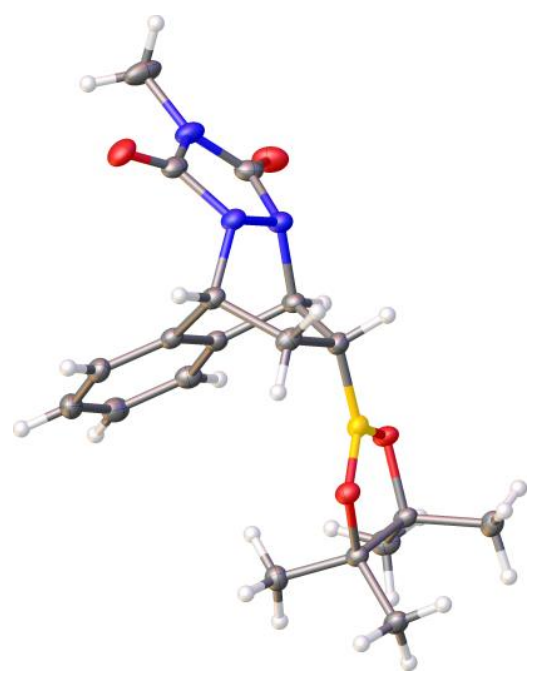

Single crystals of compound S6 were obtained by slow recrystallization from diethyl ether. A suitable crystal was selected and diffraction data were collected on a Mo Bruker D8 Venture/Photon II diffractometer. The crystal was kept at $100.01 \mathrm{~K}$ during data collection.

Identification code

Empirical formula

Formula weight
CCDC 1913279

$\mathrm{C}_{19} \mathrm{H}_{24} \mathrm{BN}_{3} \mathrm{O}_{4}$

369.22 
Temperature/K

Radiation

Crystal system

Space group

Unit cell dimensions

Volume

Z

Density (calculated)

Absorption coefficient

$\mathrm{F}(000)$

Crystal size

Theta range for data collection

Index ranges

Reflections collected

Independent reflections

Completeness to theta $=28.283^{\circ}$

Absorption correction

Max. and min. transmission

Refinement method

Data / restraints / parameters

Goodness-of-fit on $\mathrm{F}^{2}$

Final $\mathrm{R}$ indices [I $>2 \operatorname{sigma}(\mathrm{I})]$

$\mathrm{R}$ indices (all data)

Extinction coefficient

Largest diff. peak and hole
100.01

$\operatorname{MoK} \alpha(\lambda=0.71073)$

monoclinic

$\mathrm{P} 2{ }_{1} / \mathrm{n}$

$\mathrm{a}=15.5798(3) \AA \quad \alpha=90^{\circ}$

$\mathrm{b}=13.7634(2) \AA \quad \beta=100.2570(10)^{\circ}$

$\mathrm{c}=17.7218(3) \AA \quad \gamma=90^{\circ}$

3739.37(11) $\AA^{3}$

8

$1.312 \mathrm{Mg} / \mathrm{m}^{3}$

$0.092 \mathrm{~mm}^{-1}$

1568.0

$0.499 \times 0.31 \times 0.292 \mathrm{~mm}^{3}$

4.672 to $56.566^{\circ}$

$-20 \leq \mathrm{h} \leq 20,-18 \leq \mathrm{k} \leq 18,-23 \leq 1 \leq 23$

121199

$9271\left[\mathrm{R}_{\text {int }}=0.0356, \mathrm{R}_{\text {sigma }}=0.0141\right]$

$99.9 \%$

Semi-empirical from equivalents

0.7457 and 0.7106

Full-matrix least-squares on $\mathrm{F}^{2}$

9271 / 64 / 545

1.066

$\mathrm{R}_{1}=0.0361, \mathrm{wR}_{2}=0.0937$

$\mathrm{R}_{1}=0.0441, \mathrm{wR}_{2}=0.1032$

$\mathrm{n} / \mathrm{a}$

0.38 and -0.22 e. $\AA^{-3}$ 
